\title{
Aspects of Form, Tonality, and Texture in the "Farewell" Piano Sonatas of Beethoven and Dussek
}

Kyoung Cha

West Virginia University

Follow this and additional works at: https://researchrepository.wvu.edu/etd

\section{Recommended Citation}

Cha, Kyoung, "Aspects of Form, Tonality, and Texture in the "Farewell" Piano Sonatas of Beethoven and Dussek" (2012). Graduate Theses, Dissertations, and Problem Reports. 438.

https://researchrepository.wvu.edu/etd/438

This Dissertation is protected by copyright and/or related rights. It has been brought to you by the The Research Repository @ WVU with permission from the rights-holder(s). You are free to use this Dissertation in any way that is permitted by the copyright and related rights legislation that applies to your use. For other uses you must obtain permission from the rights-holder(s) directly, unless additional rights are indicated by a Creative Commons license in the record and/ or on the work itself. This Dissertation has been accepted for inclusion in WVU Graduate Theses, Dissertations, and Problem Reports collection by an authorized administrator of The Research Repository @ WVU.

For more information, please contact researchrepository@mail.wvu.edu. 


\title{
Aspects of Form, Tonality, and Texture in the "Farewell" Piano Sonatas of Beethoven and Dussek
}

\author{
Kyoung Cha \\ A Doctoral Research Project Submitted to \\ The College of Creative Arts \\ at \\ West Virginia University \\ in partial fulfillment of the requirements for the degree of \\ Doctor of Musical Arts \\ in \\ Piano Performance
}

Peter Amstutz, D. M. A., Chair and Research Advisor William Haller, D. M. A.

James Miltenberger, D. M. A.

Keith Jackson, D. M. A.

Feng Yang, PhD.

\author{
School of Music \\ Morgantown, West Virginia
}

2012

Keywords: Beethoven, Dussek, Beethoven Op. 81a, Dussek Op. 44 (C. 178), Farewell Sonata, Les Adieux, Das Lebewohl

Copyright 2012 Kyoung Cha 


\title{
ABSTRACT
}

\section{Aspects of Form, Tonality, and Texture in the "Farewell" Piano Sonatas of Beethoven and Dussek}

\author{
KYOUNG CHA
}

In the early $19^{\text {th }}$ century, two composers, Jan Ladislav Dussek (1760-1812) and Ludwig van Beethoven (1770-1827), each wrote one piano sonata with a "Farewell" title. The Bohemian musician Dussek was one of the renowned composers of his era. He was also famous as a pianist, with a brilliant and virtuosic style of playing. Beethoven was a German composer who has become enshrined as one of the major representatives of the Classical period, as well as of classical music in general. He wrote numerous masterpieces covering almost every known genre of his time, including symphony, chamber music, concerto, sonata, mass, and opera.

There is no conclusive proof that these two composers ever met or that either knew the other's music. Nonetheless, the "Farewell" sonatas by Dussek and Beethoven are both in the key of E-flat Major, and the titles of these sonatas were given by the composers themselves. Dussek's "Farewell" sonata was composed in 1800, ten years before Beethoven's. Even though detailed historical information regarding Dussek's "Farewell" sonata is not known, some scholars believe that this sonata was inspired by Dussek's departure from London, where he had lived for ten years. Beethoven's Sonata Op. 81a was composed to mourn the departure of Archduke Rudolph (1788-1831) on the approach of the French army. This sonata consists of three movements, and each movement has an individual title: (1) Das Lebewohl (Les Adieux), (2) Abwesenheit (L'Absence), and (3) Das Wiedersehen (Le Retour).

This research document presents a brief comparison of the two "Farewell" sonatas through a discussion of form, tonality, and texture. Particular focus is given to the similarities and dissimilarities between the two sonatas. This research paper consists of six chapters: (1) Introduction, (2) Review of existing literature, (3) Brief biographies of Dussek and Beethoven, (4) Brief background of the two "Farewell" sonatas, (5) Analytical views of the "Farewell" sonatas by Dussek and Beethoven, and (6) Summary and comparison. 


\section{TABLE OF CONTENTS}

\section{CHAPTER}

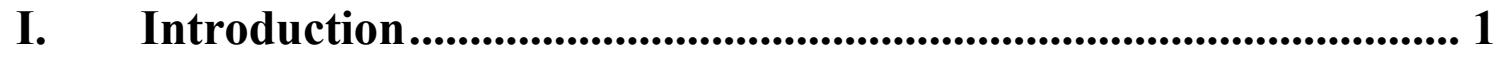

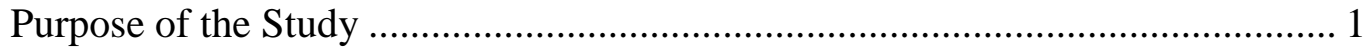

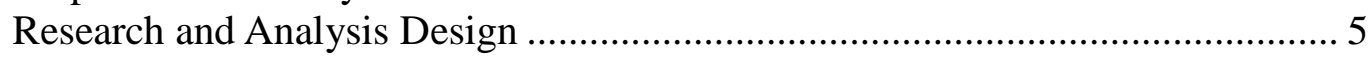

II. Review of Existing Literature .......................................................... 7

III. Brief Biographies of Dussek and Beethoven …............................. 12

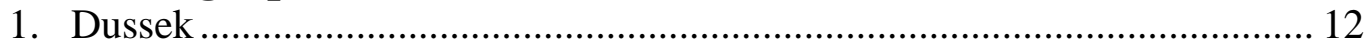

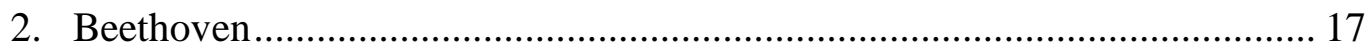

3. Did They Know Each Other's Music?........................................................... 21

IV. Brief background of the two "Farewell" sonatas.......................... 25

1. Dussek Sonata in E-flat Major, Op. 44 (C. 178) ....................................... 25

2. Beethoven Sonata in E-flat Major, Op. 81a................................................. 26

V. Analytical views of the "Farewell" sonatas by Dussek and Beethoven .......................................................................................................... 28

1. First Movements

A. First Movement of Dussek Sonata in E-flat Major, C. 178..................... 28

B. First Movement of Beethoven Sonata in E-flat, Op. 81a......................... 36

2. Second Movements

A. Second Movement of Dussek Sonata in E-flat Major, C. 178 ................ 44

B. Second Movement of Beethoven Sonata in E-flat, Op. 81a ..................... 52

3. Third Movement of Dussek Sonata in E-flat Major, C. 178 .........................56

4. Fourth Movement of Dussek and Third Movement of Beethoven

A. Fourth Movement of Dussek Sonata in E-flat Major, C.178 ................... 61

B. Third Movement of Beethoven Sonata in E-flat, Op. 81a ....................... 78

VI. Summary and Comparison .......................................................99

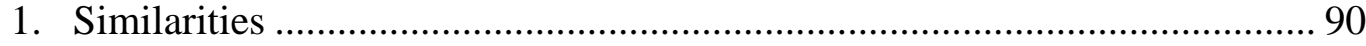

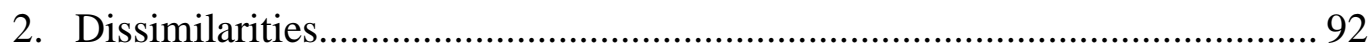




\title{
Chapter 1
}

\section{Introduction}

\author{
Purpose of the Study
}

The topic of this research paper is "Aspects of Form, Tonality, and Texture in the 'Farewell' Piano Sonatas of Beethoven and Dussek." Ludwig van Beethoven (1770-1827) and Jan Ladislav Dussek (1760-1812) each wrote one piano sonata with a "Farewell" title. This paper will explore some of the similarities and differences between those two works.

The Bohemian musician Jan Ladislav Dussek was one of the renowned composers of his era. He was also famous as a pianist, with a brilliant and virtuosic style of playing. He toured many countries, including Germany, England, France, Russia, and the Netherlands, giving public concerts. He wrote about 300 works, most of which are for piano, such as piano sonatas and piano concertos. He is believed to have composed about 32 piano sonatas, ${ }^{1}$ the same number as Beethoven. However, his piano sonatas are rarely performed now, perhaps because Beethoven's sonatas have become such predominant staples of the concert repertoire.

Ludwig van Beethoven was a German composer who has become enshrined as one of the major representatives of the Classical period, as well as of classical music in general. He wrote numerous masterpieces covering almost every known genre of his time, including symphony, chamber music, concerto, sonata, mass, and opera. He produced 32 piano sonatas, which are considered especially significant not only because they are such worthy paradigms of

\footnotetext{
${ }^{1}$ Orin Louis Grossman, "The Piano Sonatas of Jan Ludislav Dussek (1760-1812)" [PhD diss., Yale University, 1975], 12-13. 
the typical classical sonata, but also because they form a bridge between the Classic and Romantic styles of sonata.

Some scholars believe that Beethoven and Dussek influenced each other's compositional processes, though there is no evidence that they ever met each other, or even that either one knew of the other's music. In spite of this, some researchers have found similarities between piano sonatas of the two composers. One example is the parallel between the opening themes of Beethoven's Op. 10, No. 1 in C minor and Dussek's Op. 39, No. 3 in B-flat Major, which some scholars claim is strong enough to rule out coincidence. There is even some speculation that Dussek plagiarized Beethoven's idea: Eric Blom reaches this conclusion, claiming of Dussek's sonata that "a study of the first movement is almost profitless."2

${ }^{2}$ Eric Blom, Classics: Major and Minor with Some Other Musical Ruminations [New York: Da Capo, 1973], 106. 
Example 1 Beethoven Sonata in C minor, Op. 10, No. 1 (1796-1798) and Dussek Sonata in B-flat Major, Op. 39, No. 3 (1799).

Beethoven's Op. 10, No. 1 (First movement, mm. 1-5)

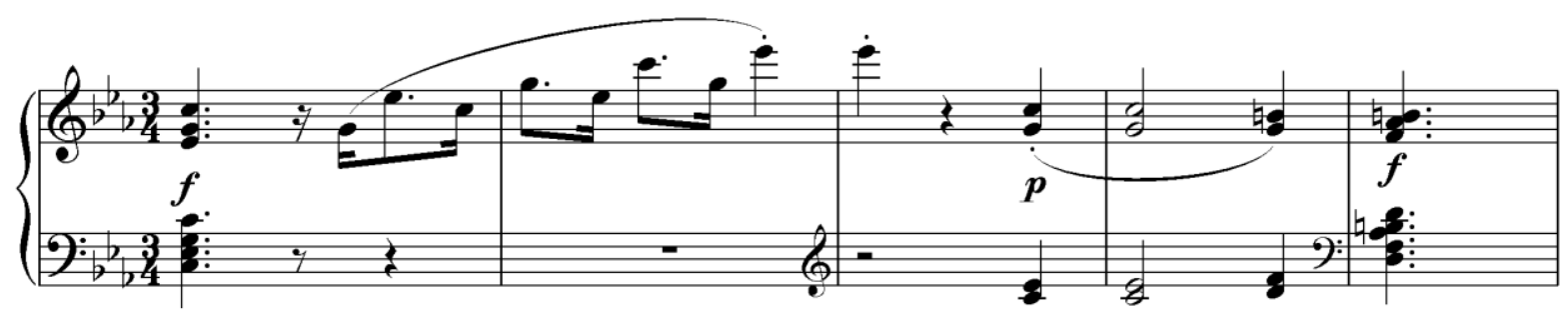

Dussek's Op. 39, No. 3 (First movement, mm. 1-4)

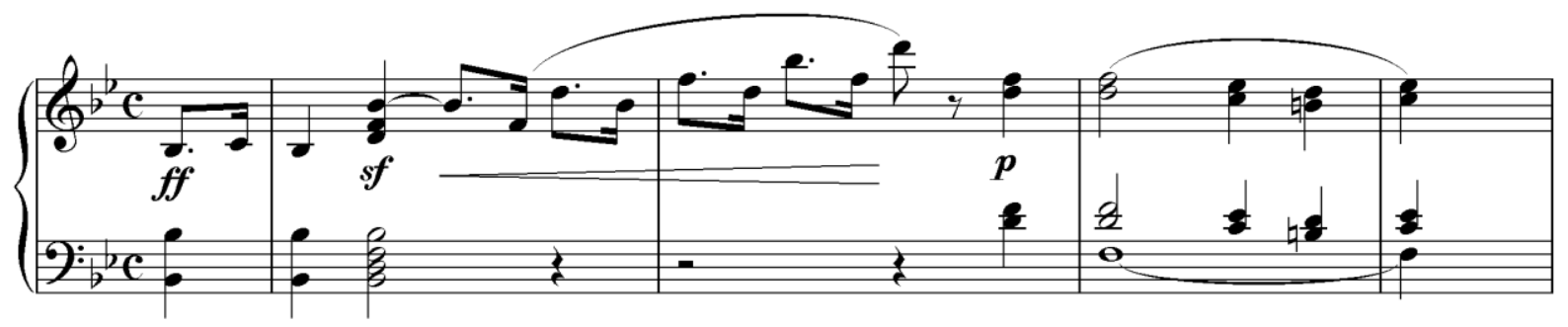

Moreover, Beethoven and Dussek each wrote a piano sonata entitled "Farewell"; both works are in the key of E-flat Major. The titles of these sonatas were given by the composers themselves; Dussek's "Farewell" sonata was composed in 1800, ten years before Beethoven's. This research document will present a brief comparison of the two "Farewell" sonatas through a discussion of form, tonality, and texture. Particular focus will be given to the similarities that can be found between the two sonatas.

The term "sonata" refers to a piece for one or more solo instruments, usually consisting of multiple movements. However, this definition can be flexible depending on the period and the style of the composer in question. In the mid-18th century, the quantity of solo keyboard sonatas was vastly increased by Domenico Scarlatti (1685-1757) and Carl Philipp Emanuel Bach (1714- 
88). Scarlatti wrote about 550 keyboard sonatas, each consisting of one movement in binary form. His sonatas were mostly played on the harpsichord. C. P. E. Bach wrote about 180 keyboard sonatas in three movements. The arrangement of the movements in his sonatas was fast-slowfast, which became a standard format for sonatas in the Classical period. His favorite instrument was the clavichord; however, he specified the fortepiano for his late sonatas. ${ }^{3}$ As Gillespie observes, some of Bach's sonatas point the way towards what came to be called sonata-allegro form:

"He seems to tread a middle path, occasionally glancing back to the Baroque and yet also looking to the future. Some of his sonata movements, hinting of things to come, show a definite development of two themes (previously expressed in correct tonal relationship) and then a recapitulation of these themes."

In the late 18th century, the piano began to assume a prominent role as a solo instrument, not only for public concerts, but also for parlor music. Therefore, the solo piano sonata became one of the dominant genres of the time. It flourished especially during the first Viennese school, as it was the beneficiary of some of the finest efforts of Haydn (1732-1809), Mozart (1756-91), and Beethoven. Haydn wrote 62 piano sonatas, Mozart composed 21, ${ }^{5}$ and Beethoven's 32 are perhaps the apex of the genre. These composers developed and standardized a set of formal precepts in their works; these characteristics have come to be regarded as the defining features of Classical sonata form. The first movement of the sonata was in sonata-allegro form (so called by later theorists), which includes three sections: exposition, development, and recapitulation. The second movement was usually in a slow tempo, in a different tonic key from that of the first

3 Stewart Gordon, A History of Keyboard Literature [New York: Schirmer Books, 1996], 86.

${ }^{4}$ John Gillespie, Five Centuries of Keyboard Music: An Historical Survey of Music for Harpsichord and Piano [Belmont, CA: Wadsworth, 1965], 151.

${ }^{5}$ Don Michael Randel, The Harvard Dictionary of Music, 4th ed. [Cambridge: Belknap Press of Harvard University Press, 2003], 796. 
movement. It could be in several different forms, with sonata, binary, ternary, and variation being the most common. If the sonata was of the four-movement variety, a dance movement was placed between the slow movement and the final movement. This movement was often a Minuet and Trio in the piano sonatas of Haydn and Mozart, but was more often a scherzo in Beethoven's works. The final movement was usually a rondo, a sonata-allegro, or a set of variations.

During the late 18th and early 19th centuries, John Baptist Cramer (1771-1858), Muzio Clementi (1752-1832), Jan Ladislav Dussek and John Field (1782-1837), who together became known as the London Pianoforte School, also composed numerous piano sonatas. They are regarded as important contemporary composers of Mozart and Beethoven, and they each enhanced their individual reputations as concert pianists.

\section{Research and Analysis Design}

This research paper will consist of six chapters: (1) Introduction, (2) Review of existing literature, (3) Brief biographies of Dussek and Beethoven, (4) Brief background of the two "Farewell" sonatas, (5) Analytical views of the "Farewell" sonatas by Dussek and Beethoven, and (6) Summary and comparison.

Chapter 2 will briefly discuss selected existing scholarly literature about Dussek and Beethoven, covering both biographical information and analysis of their "Farewell" sonatas. Chapter 3 will provide information about these two composers, including their birth, family, education, career, and other works. Chapter 4 will contain information on the two "Farewell" piano sonatas, including their dates of composition and general background. 
Chapter 5 appears in four sections, each devoted to a particular movement. In order to facilitate a comparison between the two sonatas, each of these sections will focus on the same movement in each sonata, emphasizing form, tonality, and texture. For instance, the first section of Chapter 5 will discuss the first movements of the two "Farewell" sonatas, and the second section will cover the two second movements using to the same method. The third section of the chapter will concentrate only on the third movement of the Dussek sonata, as it is a Minuet and Trio, and thus has no counterpart in the Beethoven piece, which is in three-movement format. In the last section of the chapter, the finales of the two sonatas will be studied. All four sections of this chapter will be accompanied by analytical charts.

The last chapter will present a summary of the musical ideas discussed in the previous chapters and will provide an account of the similarities and dissimilarities between the "Farewell" sonatas of Dussek and Beethoven. 


\section{Chapter 2}

\section{Review of Existing Literature}

There is already an enormous body of scholarly literature devoted to Beethoven and his sonatas. A search of databases such as RILM $^{6}$ and WorldCat ${ }^{7}$ reveals thousands of books, journals and dissertations. On the other hand, it is difficult to find much about Dussek or his piano music; even within this limited amount of material, consensus seems to be lacking. Even a question so basic as the number of piano sonatas he composed is given a different answer from one book to another. Since the research efforts of this paper focus on analysis of the "Farewell" sonatas by Beethoven and Dussek, selected literature containing these composers' biographical information and/or pre-existing analyses of the two "Farewell" sonatas is used.

\section{A History of Keyboard Literature by Gordon, ${ }^{8}$ A History of Western Music by Grout,} Burkholder, and Palisca, ${ }^{9}$ and Grove Music Online ${ }^{10}$ are helpful for biographical information and musical/cultural background for the composers. Additionally, Newman summarizes the structure and style characteristics of both Beethoven and Dussek, including their "Farewell" sonatas, in his book The Sonata since Beethoven. ${ }^{11}$

\footnotetext{
6 RILM Abstracts of Musical Literature: RILM Abstracts of Music Literature is a comprehensive music bibliography featuring citations, abstracts, and indexes.

7 WorldCat.org: Find books located in libraries around the world and use links to WVU Library content and services for easy access.

8 Gordon, A History of Keyboard Literature, 142-94, 202-3.

${ }^{9}$ Donald Jay Grout, J. Peter Burkholder, and Claude V. Palisca, A History of Western Music, 7th ed. [New York: W.W. Norton, 2006], 571-8.

10 The New Grove Dictionary of Music and Musicians. Ed. by L. Macy. http://www.newgrovemusic.com.

11 William S. Newman, The Sonata since Beethoven; the Third and Final Volume of a History of the Sonata Idea [Chapel Hill: University of North Carolina Press, 1969].
} 
Three dissertations are particularly useful in providing detailed information about Dussek and aspects of his piano sonatas: (1) A Biography and Thematic Catalog of Works of Dussek by Craw, ${ }^{12}$ (2) The Piano Sonatas of J. L. Dussek by Fortner, ${ }^{13}$ and (3) The Solo Piano Sonatas of Jan Ludislav Dussek by Grossman. ${ }^{14}$ Craw's dissertation traces the course of Dussek's life by dividing it into four major periods, with each period listed year by year, to make it easier to find the required information. Within each year, he describes Dussek's status in detail, including places that Dussek traveled to and performed, positions he held, dates of concerts, some concert programs, compositions and publication of compositions in that year. Also, he includes not only Dussek's correspondence pertaining to his music and his situation, but also sections of a journal that includes reviews of Dussek's compositions and/or concerts. In the dissertation, Craw uses his own numbering for Dussek's music, organizing it by "Craw number." This index arranges Dussek's compositions by chronological order, replacing the opus numbers. Craw believes that the opus numbers of Dussek's works are confusing, because when some of the compositions were published, they were printed by several publishers, each of whom gave a different opus number to the same work. Therefore, some of his compositions often had two or more opus numbers, and different publishers sometimes gave the same opus number to two different works. ${ }^{15}$

Fortner's dissertation covers not only biographical information but also the style of Dussek's piano sonatas. He discusses basic features of the style in these works, including their

\footnotetext{
12 Howard Allen Craw, "A Biography and Thematic Catalog of the Works of J. L. Dussek (1760-1812)" [PhD diss., University of Southern California, 1964].

${ }^{13}$ Lewis M. Fortner, "The Piano Sonatas of J. L. Dussek (1760-1812)" [master's thesis, West Virginia University, 1970].

${ }^{14}$ Grossman, The Piano Sonatas of Jan Ludislav Dussek (1760-1812).

15 Craw, A Biography and Thematic Catalog of the Works of J. L. Dussek (1760-1812), 7.
} 
length, form, performance directions, texture, and dynamics. He selects seven piano sonatas by Dussek and analyzes them briefly in order to convey their style; one of these works is the "Farewell" sonata. In his discussion of this piece, there is an emphasis on form, along with short descriptions of the key relationships and textures.

Grossman's dissertation attempts to trace Dussek's influence on his contemporaries and their music. Therefore, he approaches Dussek's career through the critical opinions about the composer expressed by the composer's contemporaries. He draws on various sources including letters, autobiography, articles, and reviews of Dussek's compositions and concerts. Grossman also studies the form, harmony, texture, and melody of Dussek's piano sonatas with examples.

While helpful points of reference, these dissertations do not provide sufficiently detailed information about Dussek's "Farewell" sonata; two of the authors broadly cover all of Dussek's works and focus on a thematic catalogue of the piano sonatas and other compositions, instead of on specific works.

Beethoven is perhaps the most renowned composer in history and his biography is already well known. There exists a wide and varied body of literature devoted to Beethoven's life and work. A valuable reference book, Thayer's Life of Beethoven by Forbes, ${ }^{16}$ provides a wealth of details about Beethoven's life. This book also presents useful information about the background of the "Farewell" sonata Op. 81a, including: (1) where he composed the piece, (2) when he composed and published the piece, (3) why he composed and titled the piece, and (4) to whom he dedicated the piece.

\footnotetext{
16 Alexander Wheelock Thayer, Elliot Forbes, Hermann Deiters, Hugo Riemann, and Henry Edward Krehbiel. Thayer's Life of Beethoven [Princeton: Princeton University Press, 1970].
} 
For detailed analysis of Beethoven's Piano Sonata Op. 81a, two books will be referred to: (1) Analysis of Form as Displayed in Beethoven's Thirty-Two Pianoforte Sonatas by Harding, ${ }^{17}$ and (2) The Classics of Music: Talks, Essays, and Other Writings Previously Uncollected by Tovey. ${ }^{18}$ Harding's book analyzes the form and tonality of the "Farewell" sonata by presenting an analytical chart. He uses different terminology from that of the present day; for example, he refers to the "enunciation," instead of the "exposition," of a sonata-allegro movement. While it is still valuable today, this book can help to trace the course of the analytical view of the sonata Op. 81a, as Harding's analysis was written in 1889 and edited in 1901.

The Classics of Music by Tovey is a comprehensive source of information about Beethoven and his "Farewell" sonata. This book is a collection of Tovey's thoughts on music, including his essays, journal articles, reviews, lectures, and broadcast talks. In the essay section of the book, he discusses Beethoven's sonata Op. 81a. His analysis of the piece compares it with other compositions by Beethoven to help readers gain a clear understanding. He refers to this sonata as a piece of "programmatic music" and explains its characteristic features with detailed analyses of its texture and structure. This book also includes a section of articles written for the Encyclopaedia Britannica (1929) about various composers. One of these composers is Beethoven, and Tovey covers not only Beethoven's biography but also the evolution of his musical style, by dividing his career into periods. In the section of lecture series in this book, Tovey provides eight lectures that discuss these three periods, tonality and key-relationship, and modulations within Beethoven's works, with examples.

17 H. A. Harding, "Sonata No. 26," in Analysis of Form as Displayed in Beethoven's Thirty-Two Pianoforte Sonatas : With a Description of the Form of Each Movement for the Use of Students [London: Novello, 1901], 52-4.

18 Donald Francis Tovey, The Classics of Music: Talks, Essays, and Other Writings Previously Uncollected [Oxford: Oxford University Press, 2001]. 
A journal article, Beethoven and the London Pianoforte School by Ringer, ${ }^{19}$ and a dissertation, The Piano Sonatas of J. L. Dussek and Ludwig van Beethoven: A Comparative Study, by Rudolf, ${ }^{20}$ offer good reference materials to help compare and contrast the two "Farewell" sonatas. Ringer discusses similarities in texture and musical ideas between the London pianoforte school (Clementi, Dussek, Cramer, and Field) and Beethoven's piano sonatas. He mentions that there are numerous similarities between the piano sonatas of Beethoven and Dussek, because both composers lived during the same period and composed piano sonatas true to common stylistic practice of the time. In order to support his opinions, he provides some specific examples of piano sonatas by Beethoven and Dussek that seem to have very similar elements of texture and thematic material.

Rudolf's dissertation is the only existing material that compares and contrasts the piano sonatas by Beethoven and Dussek. He divides his dissertation into two parts: structure and style. In the structure part, he discusses number, order and types of movements such as sonata-allegro form, rondo movements, ternary, binary, and dance movements. In the style part, he studies tonal relationship, harmony, modulation, melody, texture, and counterpoint in the Dussek and Beethoven sonatas.

Even though Ringer and Rudolf compare piano sonatas by both Dussek and Beethoven, it is difficult to construct a deep comparison between the two "Farewell" sonatas based only on their efforts, as both authors give brief coverage of all the piano sonatas by each composer. There is no literature that compares only these two piano sonatas in detail.

\footnotetext{
19 Alexander L. Ringer, "Beethoven and the London Pianoforte School," The Musical Quarterly 56, no. 4 [October 1970]: 742-58.

20 Kenneth Emanuel Rudolf, "The Piano Sonatas of J. L. Dussek and Ludwig Van Beethoven; A Comparative Study" [master's thesis, University of Washington, 1975].
} 


\section{Chapter 3}

\section{Brief Biographies of Dussek and Beethoven}

\section{Dussek}

Jan Ladislav Dussek ${ }^{21}$ was born in Č́slav, Bohemia, on February 12, 1760. He has often been confused with Mozart's friend, the composer Franz Xaver Duschek (1731-1799). ${ }^{22}$ Dussek's family members included many musicians. His grandmother, father, mother, uncle, brother and sister were all active in musical fields. ${ }^{23}$ His father, Jan Joseph Dussek (1738-1818), was an organist and elementary school teacher; ${ }^{24}$ Dussek's mother, Veronika Štěbetová, ${ }^{25}$ was a talented harpist. They had eight children, of whom Jan Ladislav was the eldest. His brother, Franz Benedikt (1765-after 1817), and his sister, Kateřina Veronika (1769-1833), also became musicians. $^{26}$

J. L. Dussek began piano lessons under his father at the age of five, and organ studies at the age of nine. ${ }^{27}$ He had a good voice and was sent to a Minorite church in Jihlava (Iglau) to be a soprano in the boys' choir. ${ }^{28}$ Dussek continued his education at the Jesuit Gymnasia of Jihlava and Kutná Hora. Later, he attended the New City Gymnasium in Prague for the school year

\footnotetext{
${ }^{21}$ There are various spelling of Dussek's name: Dussek, Dušek, Dussik, Dusiík, Duschek, Dussick, Dusseck and others. After he left his country, he used the spelling "Dussek," which is the version most common in English sources. Dusiík is the Czechoslovakian way of writing this name. Also the spelling of the first name can occur as Jan, Johann, and Jean. Additionally, several spellings of the middle name are presented: Ladislav, Ludislav, Ludwig, and Louis.

${ }_{22}$ Jan Racek, Preface to Jan Ladislav Dusiík Sonate [Praha: Editio Supraphon, 1969], XXIII.

${ }^{23}$ H. Allen Craw, Preface to Selected Piano Works [Madison: A-R Editions, 1979], vii.

${ }^{24}$ Ibid., vii.

25 Craw, A Biography and Thematic Catalog of the Works of J. L. Dussek (1760-1812), 14.

${ }^{26}$ Craw, Preface to Selected Piano Works, vii.

${ }^{27}$ Fortner, The Piano Sonatas of J. L. Dussek (1760-1812), 12.

${ }^{28}$ Ibid., 12-3.
} 
$1776-1777 .^{29}$ In 1778 , he spent one semester studying logic and philosophy at the University of Prague. $^{30}$

Dussek traveled with Captain Männer, an officer in the Austrian Artillery, to Melines (Mechelen), Belgium, and gave a successful concert on December $16,1779 .^{31}$ He stayed there to teach piano and give concerts for a short time ${ }^{32}$ and then he went to Bergen-op-Zoom, Amsterdam and The Hague. He obtained great fame as a pianist and as an educator. ${ }^{33}$ Dussek performed on July 12, 1782 in Hamburg, where he met Carl Philipp Emanuel Bach (1714-88). ${ }^{34}$ Dussek received musical advice, counsel, and perhaps some actual instruction from C. P. E. Bach. $^{35}$

He traveled to St. Petersburg in Russia and also to Lithuania in 1783, and he had a short stop in Berlin, where he probably presented one or more recitals. ${ }^{36}$ In St. Petersburg, he played at the court of Empress Catherine II and became Kapellmeister for Prince Karl Radziwill in Lithuania. From 1784 to 1786, he underwent a lengthy concert tour in Germany, including Berlin, Mainz, Kassel, Frankfurt, and Main, among other cities. He performed not only on the piano but also on a glass harmonica in these concerts. ${ }^{37}$

${ }^{29}$ Howard Allen Craw, et al. "Dussek." In Grove Music Online. Oxford Music Online, http://www.oxfordmusiconline.com/subscriber/article/grove/music/44229pg2 (accessed January 21, 2011).

${ }^{30}$ Grossman, The Piano Sonatas of Jan Ludislav Dussek (1760-1812), 24.

31 Racek, Preface to Jan Ladislav Dusiík Sonate, XXIV.

32 Howard Allen Craw, et al. "Dussek." In Grove Music Online. Oxford Music Online, http://www.oxfordmusiconline.com/subscriber/article/grove/music/44229pg2 (accessed January 21, 2011).

${ }^{33}$ Racek, Preface to Jan Ladislav Dusiík Sonate, XXIV.

34 Craw, A Biography and Thematic Catalog of the Works of J. L. Dussek (1760-1812), 27.

35 Howard Allen Craw, et al. "Dussek." In Grove Music Online. Oxford Music Online, http://www.oxfordmusiconline.com/subscriber/article/grove/music/44229pg2 (accessed February 13, 2011).

36 Fortner, The Piano Sonatas of J. L. Dussek (1760-1812), 19.

37 Howard Allen Craw, et al. "Dussek." In Grove Music Online. Oxford Music Online, http://www.oxfordmusiconline.com/subscriber/article/grove/music/44229pg2 (accessed January 21, 2011). 
After Dussek concluded his career in Germany, he went to Paris and had opportunity to give a performance at the Paris court in late $1786 .{ }^{38}$ Marie Antoinette favored him and he stayed in Paris for concerts and teaching until the French Revolution occurred in 1789. At some point during his four years in Paris, he briefly traveled to Milan to visit his brother Franz Benedikt; this was his only absence from Paris between 1786 and $1789 .{ }^{39}$

When the Revolution began in 1789, he escaped from Paris and moved to London. He remained in London for ten years and made great contributions to many London musicians. He often gave benefit concerts and piano lessons to the middle class in order to obtain financial support for musicians. ${ }^{40}$ Many of his concert series were supported by Johann Peter Salomon (1745-1815). In these concerts, he sought to perform his own his sonatas, concertos, and harpand-piano duos. During his decade in London, he met Haydn twice during the latter's London visits of 1790-92 and 1794-95. ${ }^{41}$ In Grove Music Online, Craw cites a complimentary letter that Haydn sent to Dussek's father on February 26, 1792:

"I ...consider myself fortunate in being able to assure you that you have one of the most upright, moral, and, in music, most eminent of men for a son. I love him just as you do, for he fully deserves it. Give him, then, daily a father's blessing, and thus will he be ever fortunate, which I heartily wish him to be, for his remarkable talents." 42

He also became acquainted with Muzio Clementi and J. B. Cramer. ${ }^{43}$ In 1792 , he married one of his students, Sophia Corri (1775-1847), who was a famous singer, pianist, and

\footnotetext{
38 Grossman, The Piano Sonatas of Jan Ludislav Dussek (1760-1812), 26.

39 Howard Allen Craw, et al. "Dussek." In Grove Music Online. Oxford Music Online, http://www.oxfordmusiconline.com/subscriber/article/grove/music/44229pg2 (accessed January 22, 2011).

40 Grossman, The Piano Sonatas of Jan Ludislav Dussek (1760-1812), 27.

41 Racek, Preface to Jan Ladislav Dusiík Sonate, XXIV.

42 Howard Allen Craw, et al. "Dussek." In Grove Music Online. Oxford Music Online, http://www.oxfordmusiconline.com/subscriber/article/grove/music/44229pg2 (accessed January 22, 2011).

43 Craw, Preface to Selected Piano Works, vii.
} 
harpist. ${ }^{44}$ Dussek also ran a publishing company, named Corri, Dussek and Company, with his father-in law, Domenico Corri (1746-1825). They published not only various Dussek compositions but also those by Domenico Corri and Haydn. After their business flourished for a while, they suffered a reversal of fortune and were forced to declare bankruptcy, causing Dussek to flee from London in $1799 .{ }^{45}$ After he left London, he never met his wife and daughter again, although he sent frequent messages to his wife. ${ }^{46}$

One of his achievements was to suggest extending the range of the piano. According to the famous piano company, Broadwood, he recommended an extension to the upper register of the piano. The usual range of the piano at that time was five octaves. However, additional keys were included in the upper register of the new model of the piano after his suggestion; the lower register was also extended soon thereafter. ${ }^{47}$ In 1791, the Broadwood piano's range was extended from five octaves to five and a half octaves, and then to six octaves in $1794{ }^{48}$ After the addition of the new keys, Dussek often composed passages of his sonatas in two versions, one for the usual range of the piano and the other for the extended upper register. However, he did not write music that made use of the new additions to the lower register of the piano. ${ }^{49}$

Even though we cannot be certain about the exact date of Dussek's arrival in Hamburg, most scholars presume that he appeared there either in January or February of $1800 .{ }^{50}$ He gave concerts in partnership with Ludwig Spohr (1784-1859), a Hamburg violinist and composer. In

\footnotetext{
${ }^{44}$ Fortner, The Piano Sonatas of J. L. Dussek (1760-1812), 25. There are several spellings of the first name of Dussek's father-in-law: Domenico and Dominico.

${ }^{45}$ Grossman, The Piano Sonatas of Jan Ludislav Dussek (1760-1812), 29.

${ }^{46}$ Craw, Preface to Selected Piano Works, vii.

${ }^{47}$ Grossman, The Piano Sonatas of Jan Ludislav Dussek (1760-1812), 28-9

${ }^{48}$ Howard Allen Craw, et al. "Dussek." In Grove Music Online. Oxford Music Online, http://www.oxfordmusiconline.com/subscriber/article/grove/music/44229pg2 (accessed January 23, 2011).

${ }^{49}$ Grossman, The Piano Sonatas of Jan Ludislav Dussek (1760-1812), 29.

${ }^{50}$ Fortner, The Piano Sonatas of J. L. Dussek (1760-1812), 28.
} 
1802, he traveled to his home town, Čáslav, Bohemia, to visit his parents, and also gave two concerts there (September 14 and 15). After he left Čáslav, he gave three successful concerts in Prague and met Václav Jan Křtitel Tomášek (1774-1850), a fellow composer and pianist.

Tomášek was moved by Dussek’s performance, and reported that Dussek was the first pianist to show his profile to the audience. ${ }^{51}$ During his return to Hamburg, Dussek stopped at Leipzig, Braunschweig and other places to perform. ${ }^{52}$

Dussek served as Kapellmeister for Prince Louis Ferdinand (1772-1806), an amateur composer and musician, from October 1804 to October 1806. They sometimes traveled to the battlefield together. After the prince died at the battle of Saalfeld (10 October 1806), Dussek composed Elégie harmonique sur la mort du Prince Louis Ferdinand de Prusse, Op. 61 (C. 211), to honor his memory. ${ }^{53}$ After the prince's death, Dussek served Prince Isenburg until 1807 and then moved to Paris, where he stayed until his final year. He accepted a position with Talleyrand, who was a prince of Bénévent. Talleyrand promised Dussek a good deal of time to compose and perform, and also that only a small number of duties would be given to him. ${ }^{54} \mathrm{He}$ gave a large number of concerts and taught students in Paris during this time. He often performed with two violinists, Rode (1774-1830) and Baillot (1771-1842), and a cellist named Lamare (1772-1823), at the Odéon Theater. ${ }^{55}$ In Grove Music Online, Craw cites the review of a performance reported by Méreaux:

\footnotetext{
51 Howard Allen Craw, et al. "Dussek." In Grove Music Online. Oxford Music Online, http://www.oxfordmusiconline.com/subscriber/article/grove/music/44229pg2 (accessed January 23, 2011).

52 Craw, Preface to Selected Piano Works, vii.

53 Howard Allen Craw, et al. "Dussek." In Grove Music Online. Oxford Music Online, http://www.oxfordmusiconline.com/subscriber/article/grove/music/44229pg2 (accessed January 23, 2011).

54 Fortner, The Piano Sonatas of J. L. Dussek (1760 1812), 33.

55 Craw, Preface to Selected Piano Works, viii. “C. 211” in the text refers to this work's number in Craw's catalog of Dussek's works.
} 
"In 1808, in one of the concerts given at the Odéon by Rode and Lamare, he obtained a triumph without precedent. The violin and violoncello, accustomed to being kings of all concerts, were eclipsed this time by an Erard piano under the enchanted fingers of Dussek, who had a magic of performance, a power and a charm of expression which were truly irresistible. $" 56$

Dussek died on March 20, 1812, because of gout. He spent most of his time in bed during the last month of his life because he had become too obese. He was also a heavy drinker. His burial place is not known today. ${ }^{57}$ It is widely guessed that he died either in Paris, or in Saint-German-en Laye, a suburb of Paris. ${ }^{58}$

\section{Beethoven}

Ludwig van Beethoven was born in Bonn, Germany, on December 16, 1770. His grandfather and father were musicians; both worked in the court of the elector of Cologne at Bonn. ${ }^{59}$ His father, Johann van Beethoven (c1740-1792), married a woman named Maria Magdalena (1746-1787), who bore him seven children. Only Ludwig and two brothers, Caspar Anton Carl and Nikolaus Johann, survived into adulthood. ${ }^{60}$ His father provided Beethoven with a severe musical training focused on piano and violin, with the aim of making him a famous (and

\footnotetext{
56 Howard Allen Craw, et al. "Dussek." In Grove Music Online. Oxford Music Online, as cited in Méreaux, "Les clavecinistes de 1637 à 1790: portraits et biographies des célèbres clavecinistes (Paris, 1867), 80 http://www.oxfordmusiconline.com/subscriber/article/grove/music/44229pg2 (accessed January 25, 2011).

57 Howard Allen Craw, et al. "Dussek." In Grove Music Online. Oxford Music Online, http://www.oxfordmusiconline.com/subscriber/article/grove/music/44229pg2 (accessed January 23, 2011).

58 Craw, Preface to Selected Piano Works, viii.

59 Gordon, A History of Keyboard Literature, 142.

60 Joseph Kerman, et al. "Beethoven, Ludwig van." In Grove Music Online. Oxford Music Online, http://www.oxfordmusiconline.com/subscriber/article/grove/music/40026pg1 (accessed January 31, 2011).
} 
lucrative) pianist like Mozart. ${ }^{61}$ On March 26, 1778, Beethoven gave his first public concert with one of his father's students and played "various clavier concertos and trios."62

When Ludwig was eight years old, his father sent to him to the court organist, van den Eeden (c1708-1782), from whom he received basic music-theory and keyboard lessons. ${ }^{63}$ When he was nine years old, he took a clavier lesson with Pfeiffer (c1750-1760, after 1800). ${ }^{64}$ In 1779, he met Christian Gottlob Neefe (1748-1798), who came to Bonn as the musical director of a theatrical company. Neefe became Beethoven's first important teacher ${ }^{65}$ and Beethoven studied Bach's Well-Tempered Clavier with him. ${ }^{66}$ In 1781, Neefe accepted the position of court organist. After one year, when Neefe left Bonn, Beethoven became his deputy organist, a paid position maintained by Maximilian Franz (1772-1816), in $1784 .^{67}$

In the spring of 1787, Beethoven visited Vienna, where he played for Mozart and had a few lessons from him. ${ }^{68}$ According to Gordon's book, "Mozart is said to have commented that the young man should be watched, for one day he would make his mark on the world."69 Beethoven had to cut the journey short and return to Bonn when he heard the news of his

\footnotetext{
61 Gordon, A History of Keyboard Literature, 142.

62 Joseph Kerman, et al. "Beethoven, Ludwig van." In Grove Music Online. Oxford Music Online, http://www.oxfordmusiconline.com/subscriber/article/grove/music/40026pg1 (accessed January 31, 2011). 63 Ibid.

64 Tovey, The Classics of Music, 327.

65 Joseph Kerman, et al. "Beethoven, Ludwig van." In Grove Music Online. Oxford Music Online, http://www.oxfordmusiconline.com/subscriber/article/grove/music/40026pg1 (accessed January 31, 2011).

66 Gordon, A History of Keyboard Literature, 142.

67 Joseph Kerman, et al. "Beethoven, Ludwig van." In Grove Music Online. Oxford Music Online, http://www.oxfordmusiconline.com/subscriber/article/grove/music/40026pg1 (accessed January 31, 2011).

68 Tovey, The Classics of Music, 328.

69 Gordon, A History of Keyboard Literature, 142.
} 
mother's serious illness. She died of tuberculosis on July $17,1787 .^{70}$ Beethoven stayed in Bonn for five more years to take his father's place in supporting the family. ${ }^{71}$ During that time, he became acquainted with Count Waldstein (1762-1823). Even though Waldstein was eight years older than Beethoven, he would become his close friend as well as patron.

During his travels through Bonn in 1792, Haydn heard a Beethoven cantata, which he found praiseworthy. At that time, Beethoven was given financial means by the elector and by Waldstein to go to Vienna and study with Haydn. However, he was not satisfied with Haydn as a teacher, finding that he was indifferent ${ }^{72}$ and that he corrected his exercises perfunctorily. ${ }^{73}$ Consequently, Beethoven tried to find other teachers, and secretly took a theory lesson from Johann Schenk (1753-1836). When Haydn went to London in 1794, Beethoven studied with Johann Georg Albrechtsberger (1736-1809), who stated later that Beethoven was a poor student and did not learn anything. ${ }^{74}$

Beethoven gave a concert in Vienna, in dual roles as pianist and as composer, on March 29, 1795. He played his own youthful Piano Concerto in B-flat Major (Op. 19) in the concert. ${ }^{75}$ In 1796 and 1799, he gave a concert tour that included Prague, Berlin, Dresden, and Leipzig. He also traveled to Budapest late in $1796 .^{76}$ He noticed the first signs of deafness as early as 1798 ; this condition caused him much distress and complicated his life as a musician from then on. In

\footnotetext{
70 Joseph Kerman, et al. "Beethoven, Ludwig van." In Grove Music Online. Oxford Music Online, http://www.oxfordmusiconline.com/subscriber/article/grove/music/40026pg1 (accessed January 31, 2011).

71 Tovey, The Classics of Music, 328.

72 Gordon, A History of Keyboard Literature, 143.

73 Tovey, The Classics of Music, 329.

74 Gordon, A History of Keyboard Literature, 143.

75 Joseph Kerman, et al. "Beethoven, Ludwig van." In Grove Music Online. Oxford Music Online, http://www.oxfordmusiconline.com/subscriber/article/grove/music/40026pg1 (accessed January 31, 2011).

76 Rudolf, The Piano Sonatas of J. L. Dussek and Ludwig van Beethoven, 7.
} 
1802, when he stayed in a village called Heiligenstadt, just outside Vienna, in order to improve his health and hearing, he wrote a letter which came to be called the "Heiligenstadt Testament," addressed to his two brothers. The letter gives a first-hand account of the degree to which the loss of his hearing made him despair. In 1814, he concluded his career as a concert pianist when he performed his own "Archduke" trio in April and May. ${ }^{77}$ By 1819 , it was difficult for him to communicate with others without the use of written conversation books. ${ }^{78}$

Even though the Heiligenstadt Testament shows that he considered his impending deafness to be a significant blow to his musical career, he made a fresh determination to compose works of unparalleled depth and musical quality. With these works, he rose to fame as one of the leading composers of the day. He received income through the sale of his compositions to publishers and through support from his patrons. ${ }^{79}$

In addition to his deafness, Beethoven also suffered late in life from a complicated family affair. His brother, Caspar Anton Carl, died in 1815, leaving Beethoven as the guardian of Ludwig's nephew, Karl, who was nine years old at that time. ${ }^{80}$ During Beethoven's last 12 years, despite his efforts to serve his nephew with devotion, Karl gave him constant distress and anxiety. ${ }^{81}$ Besides, Beethoven seemed unable to remain settled in one place. During his thirtyfive years in Vienna, he moved from one house to another more than 24 times. He was also often

\footnotetext{
77 Joseph Kerman, et al. "Beethoven, Ludwig van." In Grove Music Online. Oxford Music Online, http://www.oxfordmusiconline.com/subscriber/article/grove/music/40026pg1 (accessed January 31, 2011).

78 Gordon, A History of Keyboard Literature, 143.

79 Grout, A History of Western Music, 573.

80 Joseph Kerman, et al. "Beethoven, Ludwig van." In Grove Music Online. Oxford Music Online, http://www.oxfordmusiconline.com/subscriber/article/grove/music/40026pg1 (accessed February 2, 2011).

81 Tovey, The Classics of Music, 332.
} 
tormented by love. He frequently fell in love with women who were aristocratic, some of them already married. ${ }^{82}$

Beethoven was constantly active as a composer. Even though his health was not good, he had many new compositions planned at the time of his death, including a tenth symphony, music to Goethe's Faust, and more pieces of choral music. It is likely that he had a full plan in his head for many of these works. ${ }^{83}$ He died on March 26, 1827, and his funeral, open to the Viennese public, took place on March 29. ${ }^{84}$ Over ten thousand people attended to mourn the death of Beethoven. ${ }^{85}$

\section{Did They Know Each Other's Music?}

Despite the fascinating similarities between several of their compositions, there is no evidence that Dussek and Beethoven ever met each other, nor is there conclusive proof that either knew the other's music. As Rudolf observes, we know that Dussek never visited Vienna and that Beethoven rarely ventured outside that city during his adult life. ${ }^{86}$ However, there are some scholars who believe that these two composers were each influenced by the other's compositional process, whether directly or indirectly. If this is true, then there are five possible ways through which Dussek and Beethoven could have known the other's music:

\footnotetext{
82 Grout, A History of Western Music, 572-3.

83 Tovey, The Classics of Music, 332-3.

84 Joseph Kerman, et al. "Beethoven, Ludwig van." In Grove Music Online. Oxford Music Online, http://www.oxfordmusiconline.com/subscriber/article/grove/music/40026pg1 (accessed February 2, 2011).

85 Grout, A History of Western Music, 573.

86 Rudolf, The Piano Sonatas of J. L. Dussek and Ludwig van Beethoven, 8.
} 
(1) Through circumstances that arose during Dussek's concert tour in Germany during 1784-1786;

(2) through Clementi;

(3) when Beethoven met Prince Ferdinand in 1804;

(4) when Beethoven premiered his Symphony No. 7; and

(5) through publications and reviews. ${ }^{87}$

If Dussek did indeed meet Beethoven, it would have been between 1784 and 1786.

During that time, Dussek made a concert tour (performing on the piano as well as the glass harmonica) in Germany including Berlin, Mainz, Kassel, Frankfurt, and Main, among other cities. Beethoven was a court organist in Bonn at this time. ${ }^{88}$

Both Dussek and Beethoven were professionally associated with Clementi. Clementi was well known as one of the London Pianoforte School composers, along with Dussek. He was also a famous pianist, maker of instruments, and music publisher. When Dussek was in London during 1789-1799, he grew close to Clementi and their relationship continued even after Dussek left London. They often exchanged letters and Dussek sometimes asked Clementi to provide pianos and to publish his compositions. ${ }^{89}$ In April 1807, Clementi directly acquired from Beethoven the English publication rights to some of his works, including the String Quartet, Op. $59 .^{90}$

\footnotetext{
87 Rudolf, The Piano Sonatas of J. L. Dussek and Ludwig van Beethoven, 8-9.

${ }^{88}$ Craw, Preface to Selected Piano Works, vii.

89 Craw, A Biography and Thematic Catalog of the Works of J. L. Dussek (1760-1812), 109-113.

90 Margaret Cranmer and Peter Ward Jones. "Clementi." In Grove Music Online. Oxford Music Online, http://www.oxfordmusiconline.com/subscriber/article/grove/music/05937 (accessed February 11, 2011).
} 
Both Dussek and Beethoven knew Prince Louis Ferdinand, son of Prince August and a nephew of Frederick II. The Prince was two years younger than Beethoven, and demonstrated considerable musical talents. Beethoven became acquainted with the Prince and complimented him on his skill as a pianoforte player. ${ }^{91}$ When Prince Ferdinand stayed in Vienna on his way to Italy in 1804, Beethoven met him there. Ferdinand received the dedication of the Piano Concerto No. 3 in C minor when it was published it in late summer of that year. ${ }^{92}$ Dussek worked for Prince Louis Ferdinand as Kapellmeister from October 1804 to October $1806 .^{93}$ So in 1804, the two composers might have gotten to know each other's music through Prince Ferdinand.

When Beethoven premiered his Seventh Symphony on December 8, 1813, one of Dussek's compositions was listed on the program of the same concert. In Forbes' book, Thayer's Life of Beethoven, the program reads:

“I. 'An entirely new Symphony,' by Beethoven (the Seventh, in A major).

II. Two marches played by Mälzel's Mechanical Trumpeter, with full orchestral accompaniment - the one by Dussek, the other by Pleyel. III. Wellington's Victory." 94

Even if Dussek and Beethoven never met each other, they might have known each other's music through printings and reviews of their works in the same period. Dussek and Beethoven both earned great fame as composer-pianists at that time, and their compositions were widely circulated and reviewed by many publications. According to Craw, one of the German publishers, Breitkopf \& Härtel, printed seventeen piano sonatas by Dussek (C. 149, 150, 151, $166,167,168,177,178,179,180,181,184,185,211,221,247$, and 259) between 1803 and

\footnotetext{
91 Thayer, Thayer's Life of Beethoven, 185-6.

92 Ibid., 357.

93 Craw, Preface to Selected Piano Works, vii.

94 Thayer, Thayer's Life of Beethoven, 565-566.
} 
1811. ${ }^{95}$ After Dussek died, this publisher collected his piano sonatas and published them in twelve volumes. ${ }^{96}$ Beethoven also used Breitkopf \& Härtel as one of the major publishers for his compositions. This publisher printed various genres of his music, including chamber music, variations, symphony, overtures, songs, and masses. The sonatas Op. 78 and Op. 81a were

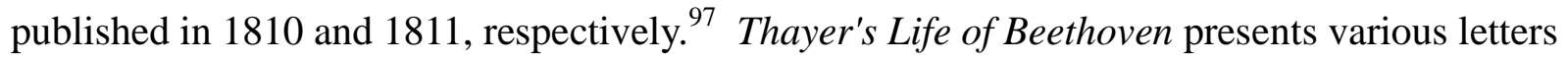
that Beethoven sent to Breitkopf \& Härtel, which prove that Beethoven had a close relationship with the publisher.

Moreover, their contemporary journal, Allgemeine musikalische Zeitung, reviewed works by Dussek and Beethoven. In The Piano Sonatas of J. L. Dussek and Ludwig van Beethoven; A Comparative Study, the author mentions that 11 piano sonatas by Dussek and 13 piano sonatas by Beethoven were reviewed in this journal between 1799 and $1812 .^{98}$

Even though there is no clear evidence that either composer was acquainted with the other or his music, there are various possible situations through which a mutual familiarity could have developed.

\footnotetext{
95 Craw, A Biography and Thematic Catalog of the Works of J. L. Dussek (1760-1812), 297, 316, 323, 324, 326, 330, 347, 353, 368, 377.

96 Ibid., 418.

97 Thayer, Thayer's Life of Beethoven, 323, 342, 478, 503, 521, 548, 816.

98 Rudolf, The Piano Sonatas of J. L. Dussek and Ludwig van Beethoven, 9.
} 


\section{Chapter 4}

\section{Brief background of the two "Farewell" sonatas}

\section{Dussek Sonata in E-flat Major, Op. 44 (C. 178)}

Dussek's Farewell Sonata was composed in 1800, ten years before Beethoven's Farewell Sonata. Detailed historical information regarding Dussek's sonata is not known. Some scholars believe that this sonata was inspired by Dussek's departure from London, where he had lived for ten years. While in London, he founded a publishing firm with his father-in-law; however, the firm went bankrupt and Dussek was forced to leave town. Grossman suggests that:

" ...the autobiographical reference is similar to his title for Op. 44, 'The Farewell,' written after his hasty, forced departure from England. It is unlikely that either title is anything more than a personal reference for purposes of publicity. There is nothing in Dussek's life or letters which suggests the Romantic conception of the suffering artist pouring out his own personal experiences into his music." 99

The sonata was written around the time that Dussek left London and arrived in Hamburg. This work was published by Longman, Clementi \& Co., and was dedicated to Clementi. Blom presents his opinion about the title of "The Farewell":

"The 'farewell' to Clementi seems to fit in best with that artist's retirement from public appearances in 1797, or possibly with his loss to the musical profession on going into business with Longman \& Hyde the following year.",100

99 Grossman, The Piano Sonatas of Jan Ludislav Dussek (1760-1812), 68.

100 Eric Blom, Classics: Major and Minor with Some Other Musical Ruminations (New York: Da Capo, 1973 ), 95. 


\section{Beethoven Sonata in E-flat Major, Op. 81a}

Beethoven's Sonata Op. 81a was composed to mourn the departure of Archduke Rudolph (1788-1831) on the approach of the French army. Rudolph left Vienna with the Empress and the Austrian royal family on May 4, 1809. ${ }^{101}$ Archduke Rudolph was the youngest son of Emperor Leopold II. When Archduke Franz, his eldest brother, became Emperor of Austria in 1792, Rudolph moved to Vienna. ${ }^{102}$ A leading patron of musicians and composers, Rudolph met Beethoven in the winter of 1803-4 and soon became his pupil and friend, in addition to providing him with financial support. ${ }^{103}$ Archduke Rudolph received composition lessons from Beethoven for more than two decades. ${ }^{104}$

This sonata consists of three movements, and each movement has an individual title: (1) Das Lebewohl (Les Adieux), (2) Abwesenheit (L'Absence), and (3) Das Wiedersehen (Le Retour). ${ }^{105}$ As cited in Thayer's Life of Beethoven, one of Beethoven's letters complains to the publisher, Breitkopf and Härtel, about the title:

"I have just received the Lebewohl, etc. I see that after all you have given French titles to other copies. Why? 'Lebewohl' is surely something very different from 'Les Adieux.' The former we say heartily to a single person, the latter to whole gatherings, whole cities." 106

\footnotetext{
101 Alexander Wheelock Thayer, Elliot Forbes, Hermann Deiters, Hugo Riemann, and Henry Edward Krehbiel, Thayer's Life of Beethoven, 464.

102 Susan Kagan. "Rudolph, Archduke of Austria." In Grove Music Online. Oxford Music Online, http://www.oxfordmusiconline.com/subscriber/article/grove/music/24087 (accessed March 10, 2011).

103 Thayer, Thayer's Life of Beethoven, 364.

104 Susan Kagan. "Rudolph, Archduke of Austria." In Grove Music Online. Oxford Music Online, http://www.oxfordmusiconline.com/subscriber/article/grove/music/24087 (accessed March 12, 2011).

105 John Gillespie, Five Centuries of Keyboard Music: An Historical Survey of Music for Harpsichord and Piano (Belmont, CA: Wadsworth, 1965), 187.

106 Thayer, Thayer's Life of Beethoven, 517.
} 
The first movement expresses a farewell to Rudolph, the second movement depicts the sadness caused by his absence, and the final movement rejoices at his return.

In Thayer's Life of Beethoven, the author cites inscriptions in Beethoven's manuscript:

"The Farewell, Vienna, May 4, 1809, on the departure of his Imperial Highness the revered Archduke Rudolph; on the Finale: The Arrival of his Imperial Highness the revered Archduke Rudolph, January 30, 1810."107

Beethoven began to compose the sonata on May 4, 1809, and he waited to complete it until Archduke Rudolph's return. Tovey tells us:

"One of the most significant biographical facts about this sonata is that Beethoven actually waited some six months after completely sketching the first movement. The dates given in the autograph of the completed work (4 May 1809, for the first movement, and 30 January 1810, for the others), refer simply to the departure and return of the Archduke."

The opus number of the sonata, 81a, was first given by Breitkopf and Härtel in their thematic catalogue of 1851 , in order to avoid confusion between two different pieces of Beethoven. The Sextet for String Quartet and Two Horns had been published as Op. 81 in 1810. Therefore, the publisher distinguished these two works by giving Op. 81a to the "Farewell Sonata" and Op. $81 \mathrm{~b}$ to the Sextet. ${ }^{109}$

\footnotetext{
107 Thayer, Thayer's Life of Beethoven, 464.

108 Tovey, The Classics of Music: Talks, Essays, and Other Writings Previously Uncollected, 35.

109 Thayer, Thayer's Life of Beethoven, 521.
} 


\section{Chapter 5}

Analytical views of the "Farewell" sonatas by Dussek and Beethoven

\section{First Movements}

\section{A. First Movement of Dussek Sonata in E-flat Major, C. 178}

The first movement of Dussek's "Farewell" sonata is constructed in sonata-allegro form, including a slow introduction. This movement consists of the usual three sections in addition to the introduction: 1) Exposition, 2) Development, and 3) Recapitulation. Detailed sectional components of the movement, including measure number and key information, are presented in the table below. 
Table 1-1 First movement of Dussek Sonata in E-flat Major, C. 178 (Sonata-allegro Form).

\begin{tabular}{|c|c|c|c|}
\hline \multicolumn{2}{|c|}{ Section } & Measure & Key \\
\hline \multicolumn{2}{|c|}{ Introduction } & $1-13$ & $\mathrm{e} b$ \\
\hline \multirow{5}{*}{ Exposition } & $1^{\text {st }}$ theme & $14-25$ & $\mathrm{~Eb}$ \\
\hline & Transition a & $25-59$ & $\mathrm{E} b \rightarrow \mathrm{B} b$ \\
\hline & $2^{\text {nd }}$ theme & $60-75$ & $\mathrm{~B} b$ \\
\hline & Transition $b$ & $76-93$ & $\mathrm{Bb}$ \\
\hline & Closing theme & $94-106$ & $\mathrm{~B} b$ \\
\hline \multirow{6}{*}{\multicolumn{2}{|c|}{ Development }} & $107-111$ & $\mathrm{E}$ \\
\hline & & $112-116$ & $\mathrm{f} \#$ \\
\hline & & $117-122$ & $a b$ \\
\hline & & $123-124$ & $\mathrm{Cb}$ \\
\hline & & $125-142$ & $\mathrm{e} b \rightarrow \mathrm{c}$ \\
\hline & & $143-159$ & $\mathrm{c}(\mathrm{V})$ \\
\hline \multirow{5}{*}{ Recapitulation } & $1^{\text {st }}$ theme & $160-171$ & $\mathrm{~Eb}$ \\
\hline & Transition $\mathrm{a}^{\prime}$ & 171-191 & $\mathrm{Eb}$ \\
\hline & $2^{\text {nd }}$ theme & $192-207$ & $\mathrm{~Eb}$ \\
\hline & Transition $b^{\prime}$ & $208-222$ & $\mathrm{~Eb}$ \\
\hline & Closing theme & $223-235$ & $\mathrm{~Eb}$ \\
\hline
\end{tabular}

The first movement of the sonata begins with a "Grave" introduction in the key of E-flat minor, the parallel minor to the E-flat Major of the main body of this movement. A significant musical element revealed in this introduction is a dotted-rhythm motive resembling Frenchoverture style and containing a melodic neighboring tone. Dussek employs this element as an essential building block throughout the movement. The main characteristic of this introductory section is a sustained melody in dotted rhythm, in 4/4 meter. Written in homophonic style with densely-textured chords, the introduction contains some melodic lines in the bass as well as the 
soprano. In addition, frequently changing dynamics, including many $s f$ markings, shape the dramatic musical expression in this section. Dominant chords are emphasized starting in m. 10, to prepare a move to E-flat Major. Example 1A-1 shows bass and soprano melodies that include the musical element with characteristic dotted rhythm of the introduction.

Example 1A-1 Dussek: "Grave" (first movement) from Sonata in E-flat Major, C. 178 (mm. 1-2, soprano and bass).

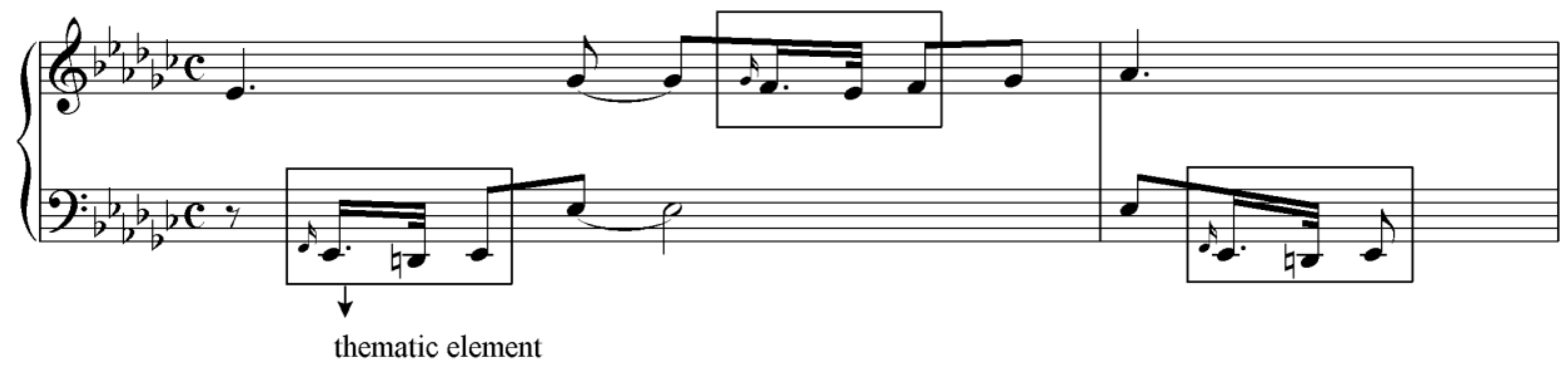

In the exposition, two main themes are introduced in different keys. In mm. 14-15, the first thematic section is presented in the key of E-flat Major. The first theme is in the parallel major key of the E-flat-minor introduction. The meter also changes from $4 / 4$ to $6 / 8$. The melody of the first theme is presented in mm 14-16. This melody is based on material from the beginning of the introduction, but it changes the mood by employing different mode, tempo, and rhythm. When this theme appears, it is doubled by another line a sixth below. 
Example 1A-2 Dussek: "Allegro moderato" (first movement) from Sonata in E-flat Major, C. 178 (mm. 14-17).

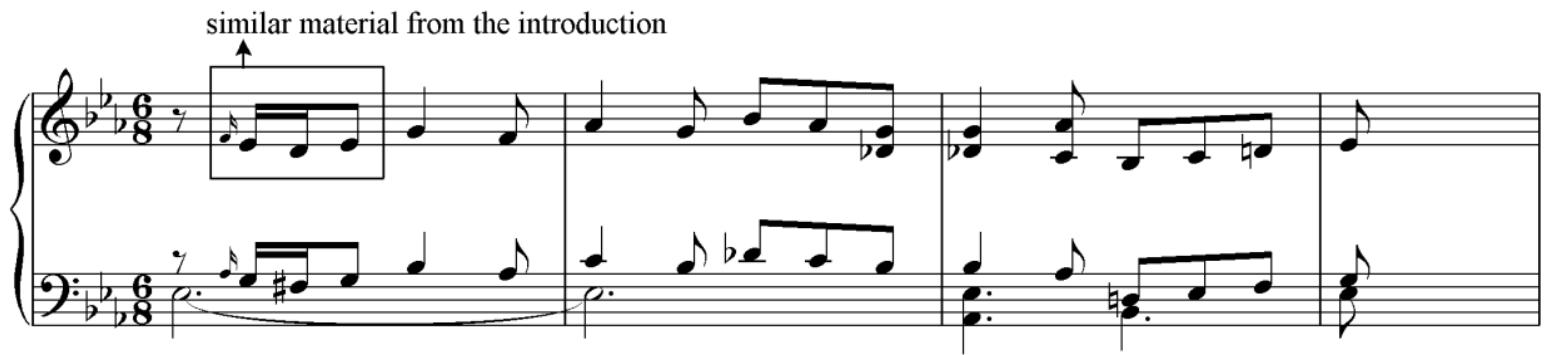

After the first phrase, in mm. 17-19 the original melody is joined by a second voice a third above the original; then in mm. 20-22 it alternates with parallel octaves in the left hand, accompanied by sixteenth notes in the inner voice of the right hand. This sixteenth-note accompaniment is based on the tenor part in m. 14 (see example 1A-2), and it presents a figure that is an inversion of the parallel octaves of $\mathrm{m} .14$ in m. 20.

Example 1A-3 Dussek: “Allegro moderato" (mm. 17-23).

mm. 17-19

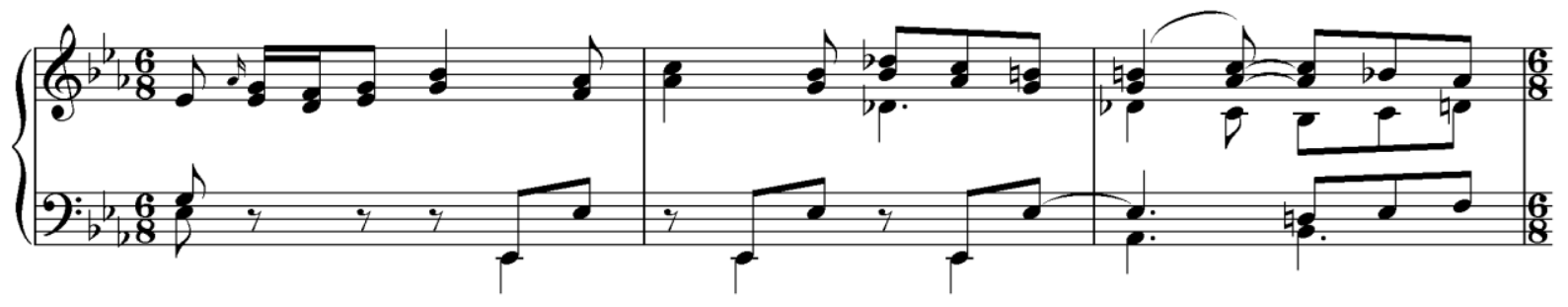

mm. $20-23$

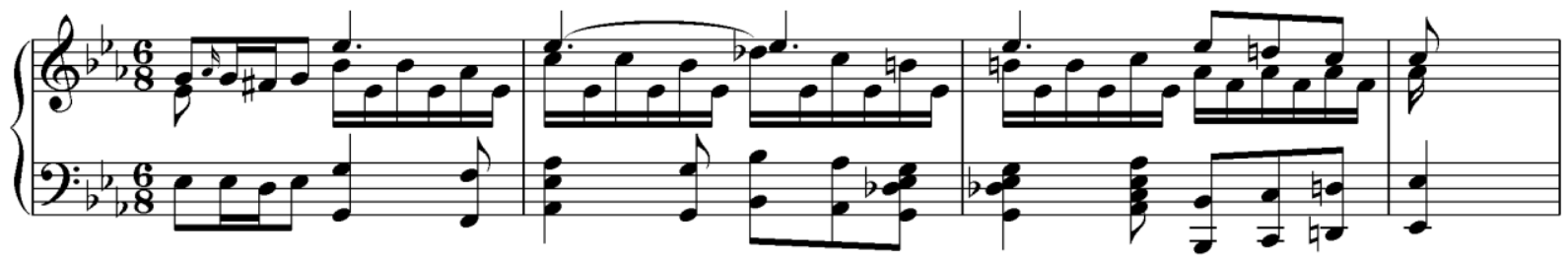


The phrase structure of the first thematic section is symmetrical, but the three individual motives show an unusual combination of $3+3+6$ measures, respectively. This first section ends in m. 42 with an imperfect cadence. Polyphonic texture is maintained throughout most of this section. However, we see homophonic texture in mm. 35-38. As in the introduction, sudden contrasts in dynamics from $\boldsymbol{p}$ to $f f$ occur frequently.

Mm. 25-59 reveal a prolonged transition section that is connected with the second theme. Sixteenth-note figurations dominate in this passage, and a fragment of the dotted rhythm from the introduction is also used as a tool for the modulation to the dominant key. Dussek moves from E-flat Major to B-flat Major by way of G minor and B-flat minor. Fortner mentions the modulatory pattern of this transition in his dissertation:

"This transition wastes little time in getting to the dominant (B-flat), but its arrival there is not accompanied by any kind of strong cadence so that the modulation is not as strong as it might be."110

Example 1A-4 Dussek: “Allegro moderato" (mm. 43-44).

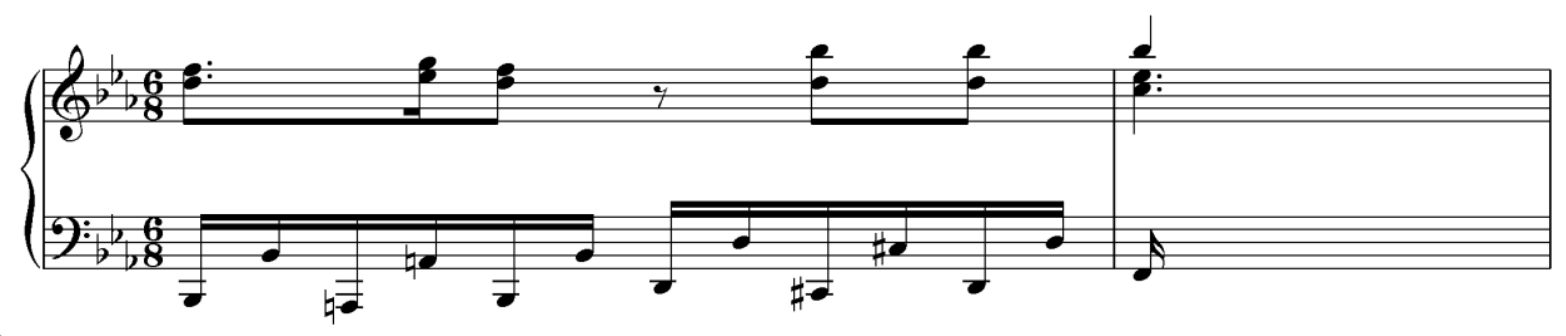

The second thematic group begins in m. 60 in the new tonic of B-flat Major, the dominant key of E-flat Major. Dussek uses a rhythm that is the retrograde of the first theme's rhythm for the melody of the second theme. The second theme consists of an eight-measure

${ }^{110}$ Fortner, The Piano Sonatas of J. L. Dussek (1760-1812), 112. 
phrase that can be subdivided into small groups of two measures. This theme then recurs with sixteenth-note accompaniment. The texture of the second theme is polyphonic and the melody is often doubled at the sixth. In contrast with the first thematic group, the second theme concludes with authentic cadence in mm. 75 and 76.

Example 1A-5 Dussek: “Allegro moderato” (mm. 60-63).
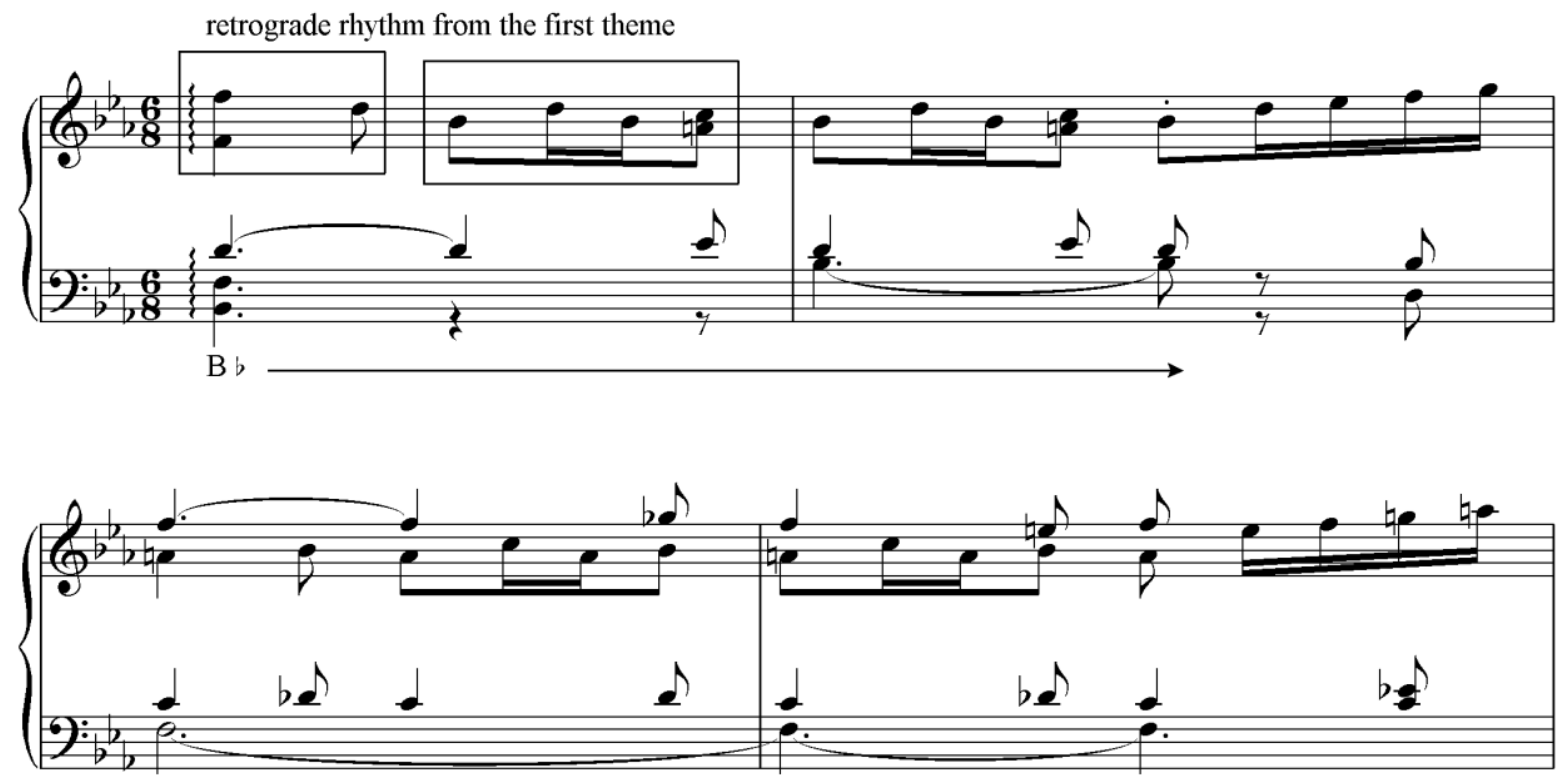

b b

After a second transition, the closing theme, in B-flat Major, appears in m. 94. This theme is made up of the same material found in the introduction and the first theme. This material reprises many times in different registers, followed by a repeat of the exposition. 
Example 1A-6 Dussek: “Allegro moderato" (mm. 94-95).

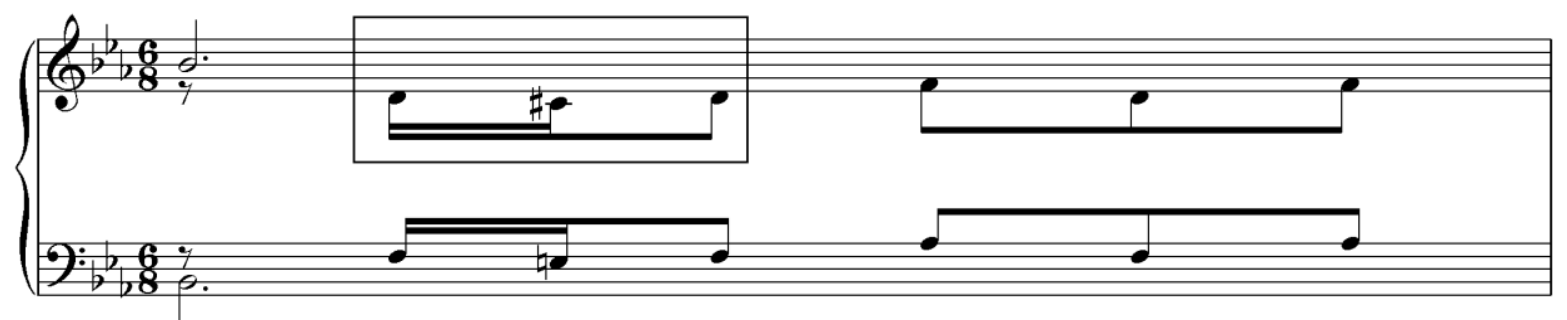

The development section includes several key areas that are quite remote from the main tonic of this movement. After the exposition ends in the key of B-flat, a B-natural suddenly appears in the bass in $\mathrm{m} .107$, playing the role of the dominant for the new key of the development section. This key of E Major, which is far away harmonically from the home key of E-flat Major, comes as a great surprise.

Example 1A-7 Dussek: “Allegro moderato” (mm. 106-108).

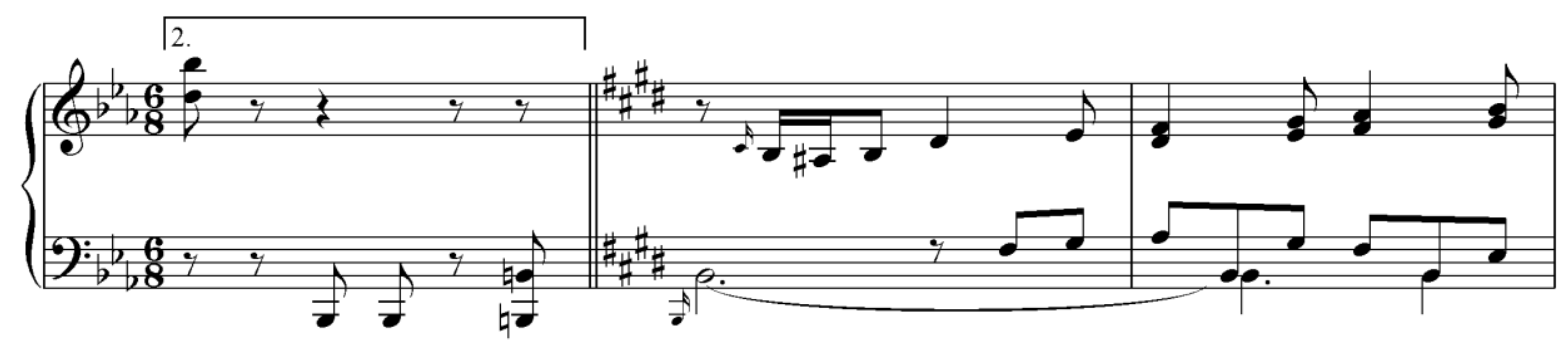

In the beginning of the development section, Dussek structures an unusual five-measure phrase based on the idea of the first theme. This phrase then recurs in F-sharp minor (m. 112) and A-flat minor (m. 117), followed by a prolonged sequential passage in which the common 
fragmented rhythm of the first and second themes appears. The tonal direction through this extended sequence is from $\mathrm{C}$-flat to $\mathrm{C}$ minor.

From m. 143 to the end of the development section, the dominant of $\mathrm{C}$ minor is emphasized via several harmonic elaborations, including secondary diminished chords of the dominant in $\mathrm{m} .154$. Grossman mentions the dominant pedal tone presented in $\mathrm{m} .152$ :

"Another effective elaboration of the pedal preparing the recapitulation is the deceptive pedal....In the first movement of Op. 44, Dussek ends the development with a dominant pedal on g....Since the home key is E-flat major, this pedal is on $\mathrm{V}$ of the relative minor. After a fermata on the $\mathrm{G}$ triad, the recapitulation begins abruptly in E-flat major...."111

Example 1A-8 Dussek: “Allegro moderato” (mm. 155-156).

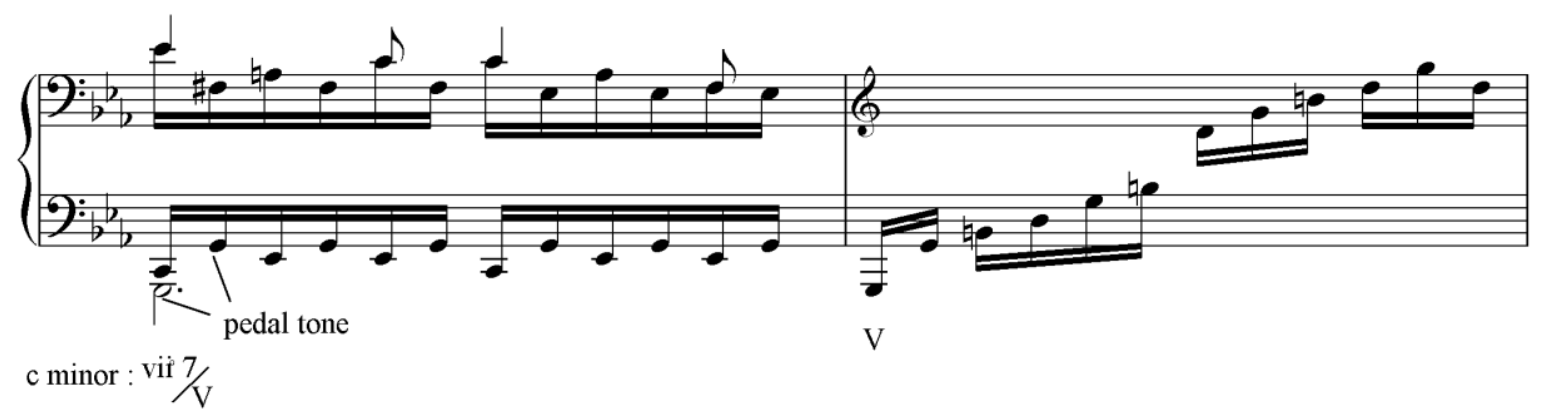

The recapitulation starts in $\mathrm{m} .160$, and the first, second, and closing themes are all presented in E-flat Major. Every formal structure in the recapitulation is very similar to that of the exposition, except for a shortened transition, which is reduced in size by several measures.

111 Grossman, The Piano Sonatas of Jan Ludislav Dussek (1760-1812), 112. 


\section{B. First Movement of Beethoven Sonata in E-flat, Op. 81a}

The first movement of Beethoven's "Farewell" sonata is constructed in sonata-allegro form with a slow introduction, in the same manner as Dussek's first movement. This movement consists of five sections: 1) Introduction, 2) Exposition, 3) Development, 4) Recapitulation, and 5) Coda. Details of each section, including measure number and key information, are presented in the table below. 
Table 1-2 First movement of Beethoven Sonata in E-flat, Op. 81a (Sonata-allegro Form).

\begin{tabular}{|c|c|c|c|c|}
\hline \multicolumn{3}{|c|}{ Section } & Measure & Key \\
\hline \multicolumn{3}{|c|}{ Introduction } & $1-16$ & $\mathrm{~Eb}$ \\
\hline \multirow{6}{*}{ Exposition } & \multirow{2}{*}{$1^{\text {st }}$ theme } & $1^{\text {st }}$ section & $17-20$ & $\mathrm{~Eb}\left(\mathrm{IV}_{6}\right)$ \\
\hline & & $2^{\text {nd }}$ section & $21-29$ & $\mathrm{~Eb}$ \\
\hline & \multicolumn{2}{|c|}{ Transition a } & $29-49$ & $\mathrm{E} b \rightarrow \mathrm{B} b$ \\
\hline & \multicolumn{2}{|c|}{$2^{\text {nd }}$ theme } & $50-57$ & $\mathrm{~B} b$ \\
\hline & \multicolumn{2}{|c|}{ Transition $b$} & $58-61$ & $\mathrm{~B} b$ \\
\hline & \multicolumn{2}{|c|}{ Closing theme } & $62-69$ & $\mathrm{~B} b$ \\
\hline \multirow{2}{*}{\multicolumn{3}{|c|}{ Development }} & $70-90$ & $\begin{array}{l}\mathrm{c}(\mathrm{V}) \rightarrow \mathrm{b} b \rightarrow \mathrm{G} \rightarrow \mathrm{b} b \\
\rightarrow \mathrm{e} b \rightarrow \mathrm{G} b \rightarrow \mathrm{c} \rightarrow \mathrm{E} b\end{array}$ \\
\hline & & & $91-109$ & $\mathrm{~A} b(\mathrm{~V} 7) \rightarrow \mathrm{c}$ \\
\hline \multirow{6}{*}{ Recapitulation } & \multirow{2}{*}{$1^{\text {st }}$ theme } & $1^{\text {st }}$ section & $110-113$ & $\mathrm{~Eb}$ \\
\hline & & $2^{\text {nd }}$ section & $114-122$ & $\mathrm{~Eb}$ \\
\hline & \multicolumn{2}{|c|}{ Transition a' } & $122-141$ & $\mathrm{E} b$ \\
\hline & \multicolumn{2}{|c|}{$2^{\text {nd }}$ theme } & $142-149$ & $\mathrm{~Eb}$ \\
\hline & \multicolumn{2}{|c|}{ Transition $b^{\prime}$} & $150-153$ & $\mathrm{~Eb}$ \\
\hline & \multicolumn{2}{|c|}{ Closing theme } & $154-161$ & $\mathrm{~Eb}$ \\
\hline & \multirow{4}{*}{\multicolumn{2}{|c|}{ Coda }} & $162-166$ & $f\left(V_{6}\right)$ \\
\hline & & & $167-180$ & $\mathrm{f} \rightarrow \mathrm{e} b$ \\
\hline & & & $181-222$ & $\mathrm{e} b \rightarrow \mathrm{Eb}$ \\
\hline & & & $223-255$ & $\mathrm{~Eb}$ \\
\hline
\end{tabular}

The movement begins with an "Adagio" introduction in E-flat Major. This introduction includes two important elements [(a) and (b)], presented in mm. 1 and 2. The first element (a) is a descending three-note step-wise figure, G-F-E $b$; the second element (b) is a rising fourth in scale motion. Element (a) has an especially significant role as a thematic source; this motive also unifies the movement through its various appearances in augmentation and diminution. 
Example 1B-1 Beethoven: "Adagio" (first movement) from Sonata in E-flat Major, Op. 81a (mm. 1-2, showing (a) and (b) elements).
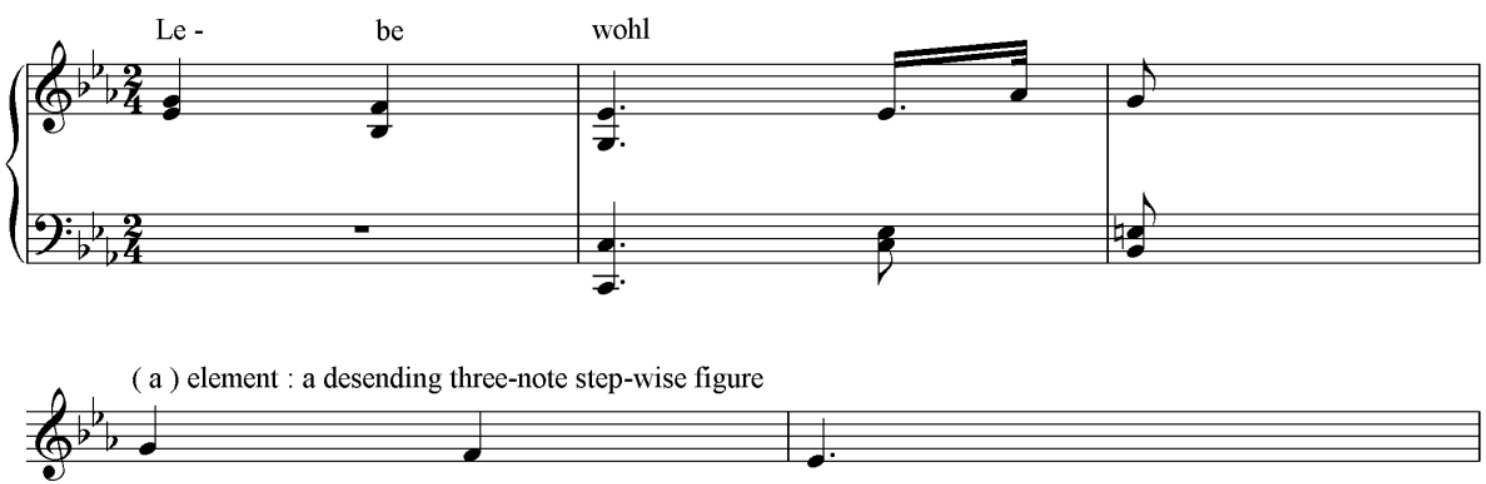

(b ) element : a rising fourth

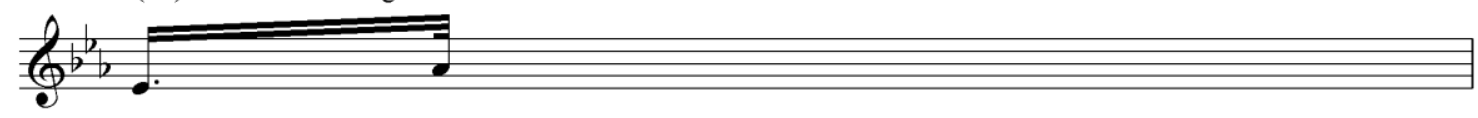

The melody of the introduction is shaped into six measures of 2/4 meter. When the (a) element appears in the first six-measure phrase, it is harmonized by a deceptive cadence. It is followed by the rising fourth element (b) over a descending bass line in contrary motion. When this phrase is reprised in $\mathrm{m} .7$, with more voices added, the (a) element is suddenly interrupted by a new C-flat-Major tonic chord, and the (b) element is elaborated through ornamentation.

According to Tovey's idea for measure 13:

"The bass has been descending in fragments of scale which, like every descending scale figure in the whole introduction and first movement, suggest a diminution of the "Lebewohl" figure, and this process of descending scale is continued by the bass in broken phrases, with the treble rising in contrary motion. ${ }^{112}$

112 Tovey, The Classics of Music, 28. 
Example 1B-2 Beethoven: “Adagio" (m. 13).

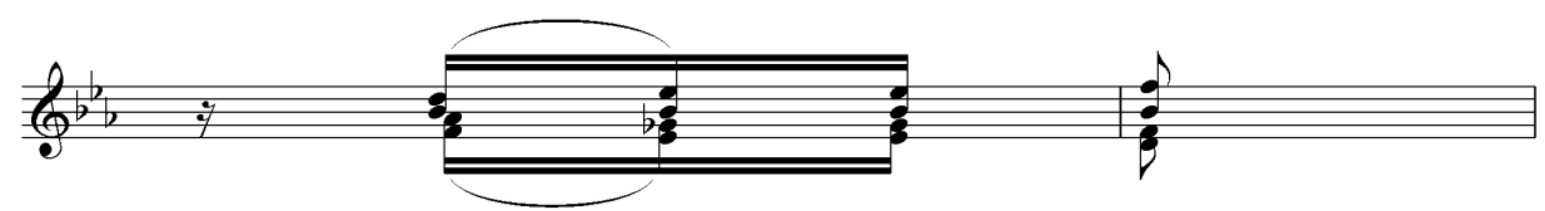

The exposition, consisting of two main themes, begins in an allegro tempo in $2 / 2$ meter. In mm. 17-29, the first theme is presented in E-flat Major; rather unusually, this theme begins on a subdominant chord in first inversion, in place of tonic harmony. This first theme can be divided into two small sections. The first section is structured in four measures (mm.17-20); two elements from the introduction are adjusted and combined to create the melody of this section. A descending half-step also appears in the bass line, creating a sense of contrary motion with the uppermost voice.

Example 1B-3 Beethoven: "Allegro" (first movement) from Sonata in E-flat Major, Op. 81a (mm. 17-19).

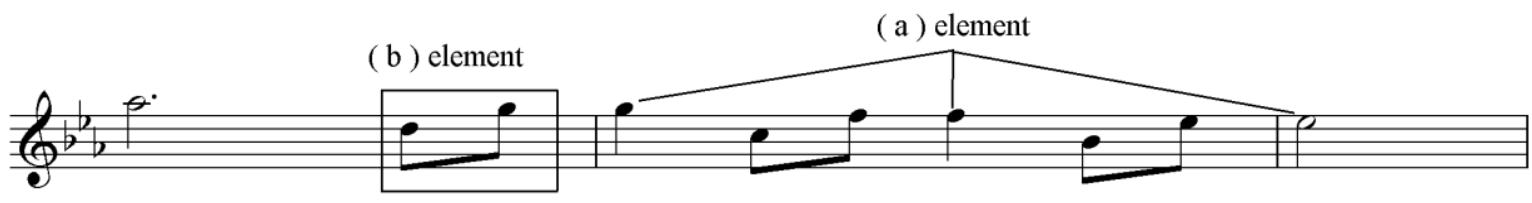

The subsequent eight measures, mm. 20-28, feature a melody-and-accompaniment texture, in contrast to the chordal texture that dominated the previous sections. The melody is played in octaves, and it is accompanied by eighth-note patterns that establish the tonic of E-flat 
Major. In addition, the downbeats of this eighth-note accompaniment outline the notes of the (a) element of the introduction in retrograde.

Example 1B-4 Beethoven: "Allegro" (mm. 21-23, left hand).

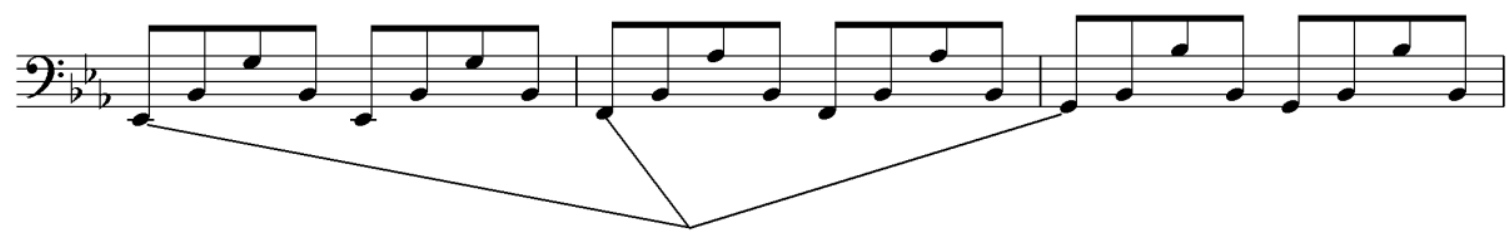

(a ) element in reverse

Like the first theme, the transition section that follows also includes two subdivided sections. The first section emerges in $\mathrm{m} .29$, and is based on descending and ascending scales in contrary motion.

Example 1B-5 Beethoven: "Allegro" (mm. 29-31, the soprano and the bass line).

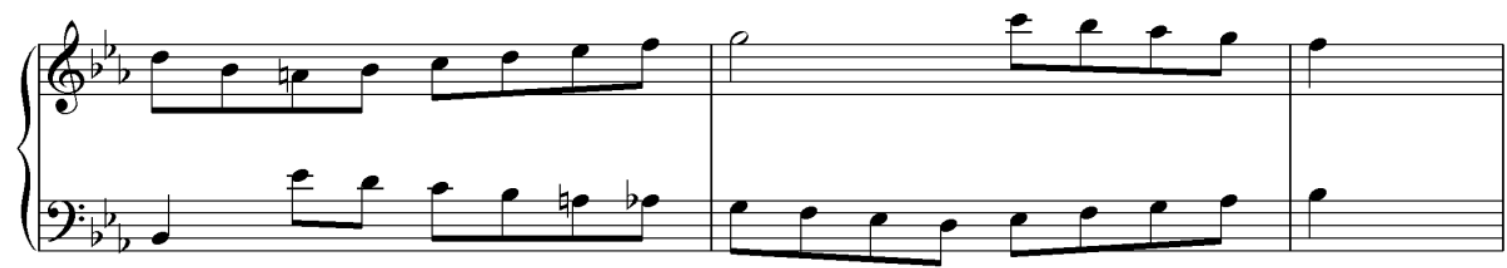

Beethoven bases the second section of this transition on the (a) element. In mm. 35-36, the bass line traverses the (a) element, the step-wise descending three notes, while the soprano line moves in contrary motion. 
Example 1B-6 Beethoven: “Allegro” (mm. 35-36, the soprano and the bass).

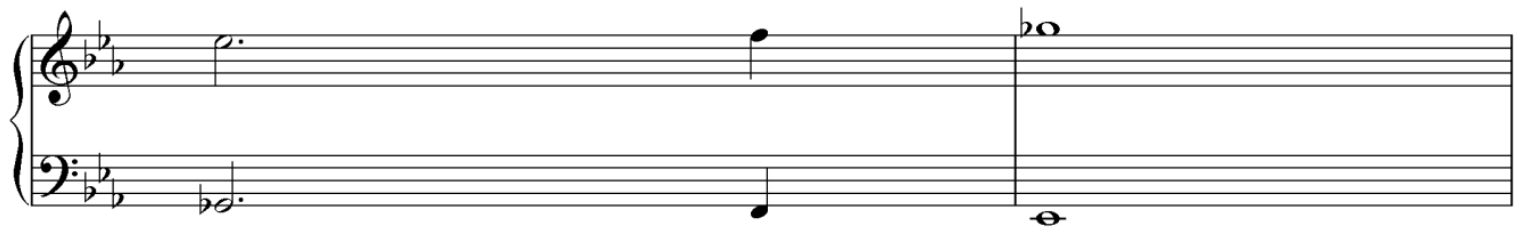

In $\mathrm{mm} .50-58$, the second theme, also rooted in the (a) element, is presented in long notes with an augmented figure in B-flat Major, the dominant key of E-flat Major. When the secondtheme melody appears in whole notes, the melody is accompanied by an eighth-note figure that had appeared in the transition in an inner voice. The bass sustains a B-flat pedal tone to help emphasize the dominant key. This second theme consists of four measures, and this theme is repeated in a lower octave after its first appearance.

Example 1B-7 Beethoven: “Allegro” (mm. 50-53).

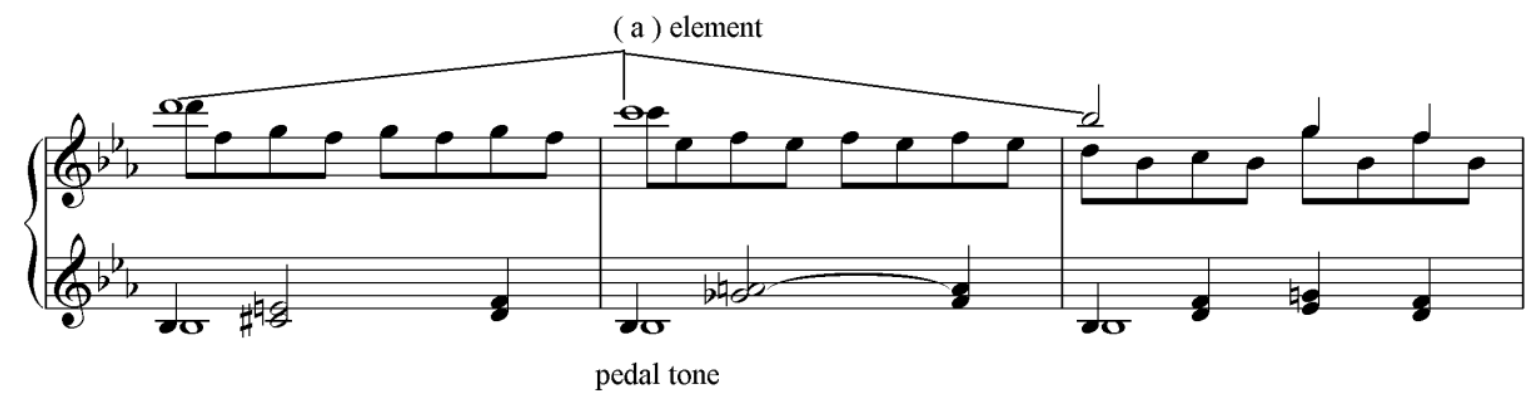

The B-flat-Major closing theme is also based on the (a) material, using canonic and syncopated motion in alternating voices. 
Example 1B-8 Beethoven: “Allegro" (mm. 62-63).

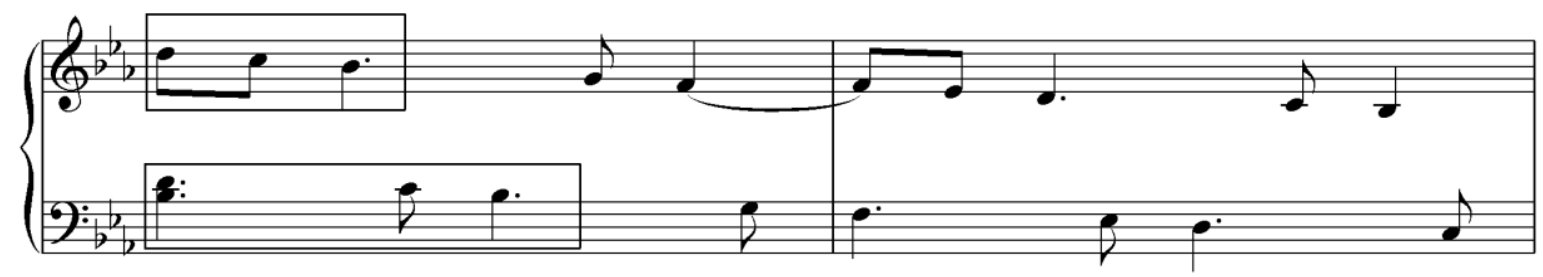

After the exposition is repeated, the development section opens with the first section of the first theme in $\mathrm{C}$ minor. Beethoven then combines the (a) and (b) elements, with long notes taken from the (a) element in the right hand, and the (b) element in the left hand. This development section contains five different key areas: C minor, B-flat minor, G-Major, E-flat minor, and G-flat Major; these key areas are mostly reached via sequential patterns.

Example 1B-9 Beethoven: “Allegro” (mm. 73-76).

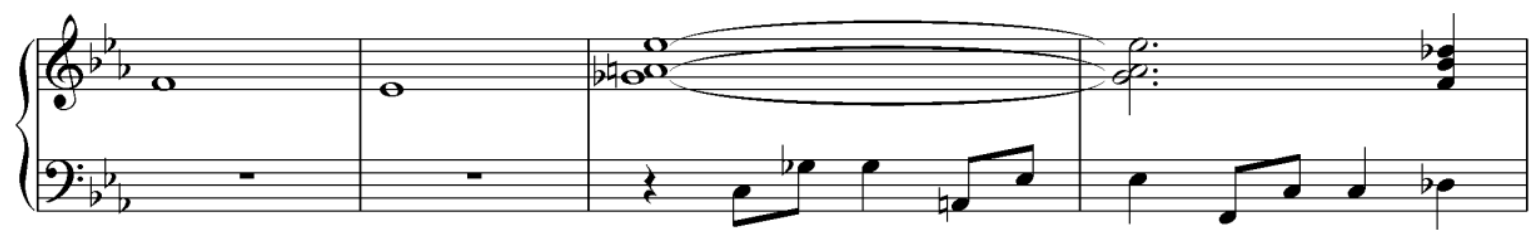

The recapitulation section starts in $\mathrm{m} .110$, and all themes from the exposition return in the home key of E-flat Major. The themes are presented in an identical manner to the exposition, except for slight changes to the bass in the second section of the first theme. 
Example 1B-10 Beethoven: "Allegro" (mm. 118-119, the bass line).

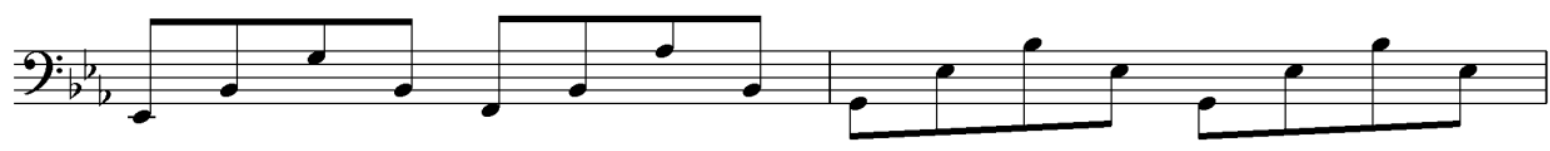

This movement contains a coda which is longer than any of the other three main sections of the movement. This coda can be divided into three parts. The first part opens with the first theme of the exposition in F minor, the supertonic of E-flat Major. This section is more extended than the first theme, with a repeated section at the end. In $\mathrm{m} .181$, the second part begins with a dialogue between two voices using the long notes of element (a). The beginning of this section is still in minor, but it moves to E-flat Major during alternations of the melody.

Example 1B-11 Beethoven: “Allegro” (mm. 181-187).

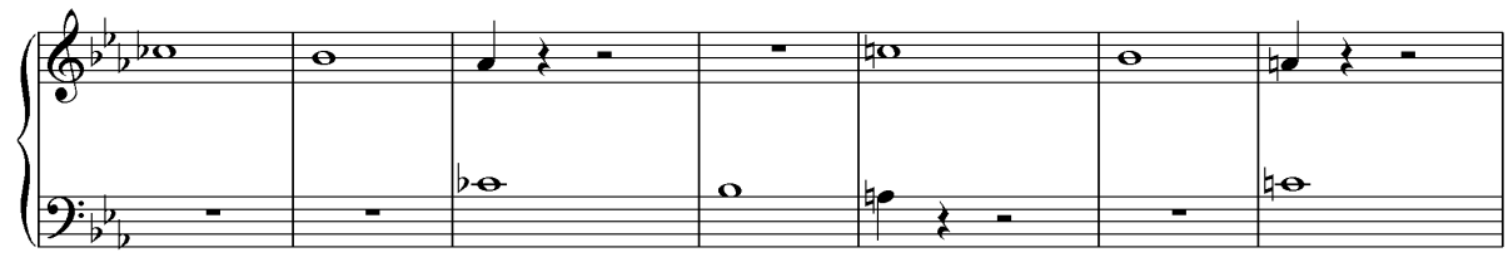

After this dialogue, Beethoven brings back the whole-note (a) element with eighth-note counterpoint. These eighth notes move freely above and below the melody. 
Example 1B-12 Beethoven: “Allegro” (mm. 197-199).

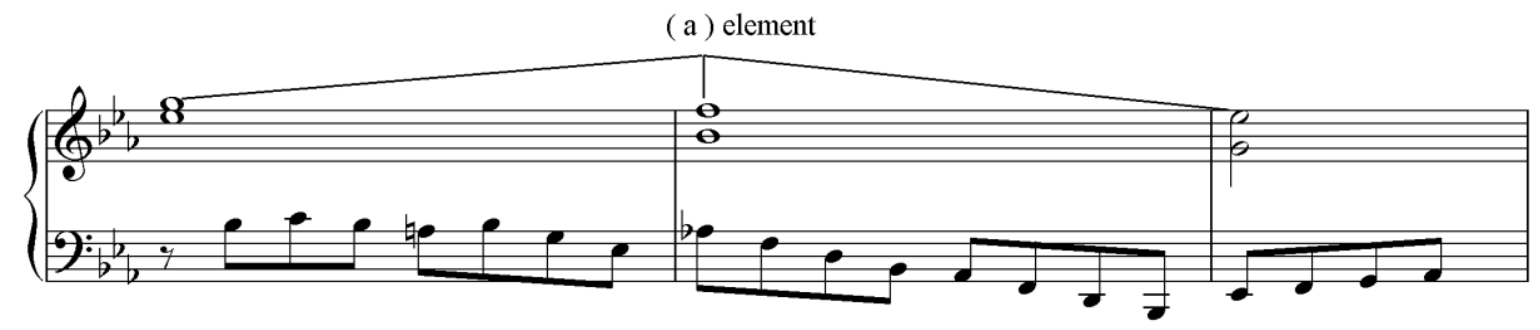

In $\mathrm{m} .223$, the third section of the coda begins. In this section, Beethoven uses imitation of the lower notes of the "Lebewohl" (see example 1B-1) first, and then exchanges the entire "Lebewohl" motive between the two hands.

Example 1B-13 Beethoven: “Allegro” (mm. 223-231).

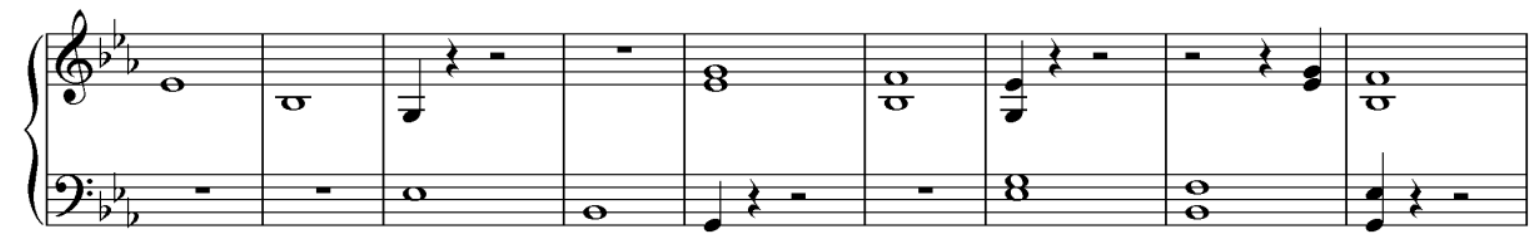

\section{Second Movements}

\section{A. Second Movement of Dussek Sonata in E-flat Major, C. 178}

The form of this movement has been analyzed in different ways. Fortner suggests that "Like many of Dussek's slow movements this adagio is in an ABA form."113 However,

113 Fortner, The Piano Sonatas of J. L. Dussek (1760-1812), 116. 
Grossman insists that this movement is a sonata form:

"There is one such case in Dussek's work, the slow movement of Op. 44 (1800). This harmonically complex work is a rather free sonata form. An impassioned middle section, loosely based on exposition material, serves as a development.",114

In the author's opinion, the second movement of Dussek's "Farewell" sonata is constructed in a sonata form, because it consists of the usual three sections: 1) Exposition, 2) Development, and 3) Recapitulation. The Exposition contains two contrasting themes, which return in the home key during the Recapitulation. Detailed sectional components of the movement, including measure number and key information, are presented in the table below.

Table 2-1 Second movement of Dussek Sonata in E-flat Major, C. 178 (Sonata Form).

\begin{tabular}{|c|c|c|c|}
\hline \multicolumn{2}{|c|}{ Section } & Measure & Key \\
\hline \multirow{4}{*}{ Exposition } & $1^{\text {st }}$ theme & $1-8$ & $\mathrm{~B}$ \\
\hline & Transition & $9-25$ & $\mathrm{~B} \rightarrow \mathrm{F} \#$ \\
\hline & $2^{\text {nd }}$ theme & $26-33$ & $\mathrm{~F} \#$ \\
\hline & Closing theme & $34-37$ & $\mathrm{~F} \#$ \\
\hline \multicolumn{2}{|c|}{ Development } & $38-67$ & $\begin{array}{c}\mathrm{F} \# \rightarrow \mathrm{f} \# \rightarrow \mathrm{c} \# \rightarrow \mathrm{g} \# \rightarrow \mathrm{d} \# \\
\rightarrow \mathrm{b} b \rightarrow \mathrm{b} \rightarrow \mathrm{B}\end{array}$ \\
\hline \multirow{4}{*}{ Recapitulation } & $1^{\text {st }}$ theme & $68-75$ & B \\
\hline & Transition & $76-84$ & $\mathrm{~B}$ \\
\hline & $2^{\text {nd }}$ theme & $85-92$ & B \\
\hline & Closing theme & $93-96$ & B \\
\hline
\end{tabular}

The key of this movement is B Major, a remote key from the tonic of the first movement, E-flat Major. Newman includes this movement when he mentions Dussek's use of "More remote

114 Grossman, The Piano Sonatas of Jan Ludislav Dussek (1760-1812), 107. 
keys, like the lowered submediant major spelled enharmonically."115 Grossman also refers to key relationships:

“...In the sonata Op. 44 in E-flat (1800), which we have previously cited as one of Dussek's most complex works. The lowered sixth relationship is expanded to govern his choice of keys for the four-movement cycle. The first and last movements are in E-flat. The second movement is in B major, the enharmonic equivalent of C-flat." 116

In the exposition, two main themes and a closing theme are introduced. In mm.1-8, the first theme, characterized by dotted rhythm, is presented in $2 / 4$ meter. Newman remarks on the relation between this theme and the themes of other movements:

"Nearest to interrelated themes are the similarly contoured, mostly dotted, incipits in all four movements of 'The Farewell' (C.178).,"117

Example 2A-1 Dussek: "Molto adagio e sostenuto" (second movement) from Sonata in E-flat Major, C. 178 (mm. 1-2).

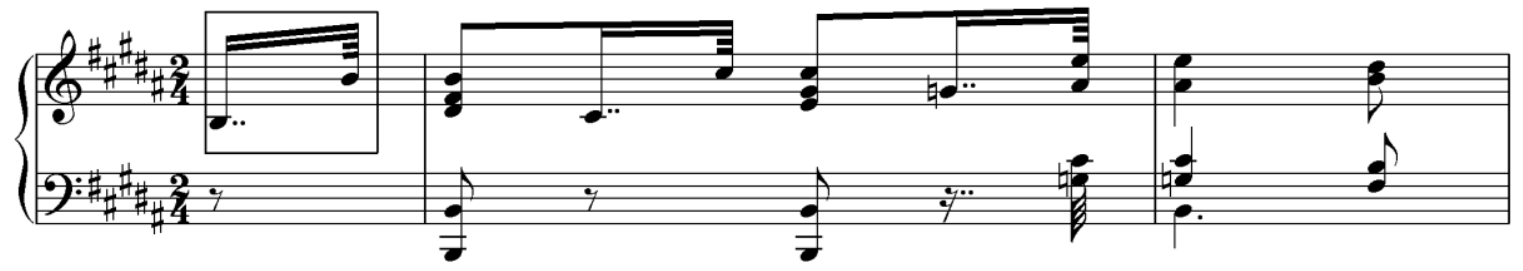

The melody of the first theme is made up of the dotted-rhythmic pattern found in the introduction of the first movement. The phrase structure of the first theme is periodic, $2+2+4$, and the texture is homophonic with octaves in the left hand and chords in the right hand.

\footnotetext{
115 Newman, The Sonata since Beethoven, 666.

116 Grossman, The Piano Sonatas of Jan Ludislav Dussek (1760-1812), 151-152.

117 Newman, The Sonata since Beethoven, 666.
} 
The transition section can be divided into two small parts. The first part of the transition starts in $\mathrm{m} .8$, with an upper-neighbor figure in the melody. The first phrase is an unusual $5+5$ combination.

Example 2A-2 Dussek: "Molto adagio e sostenuto" (mm. 9-10).

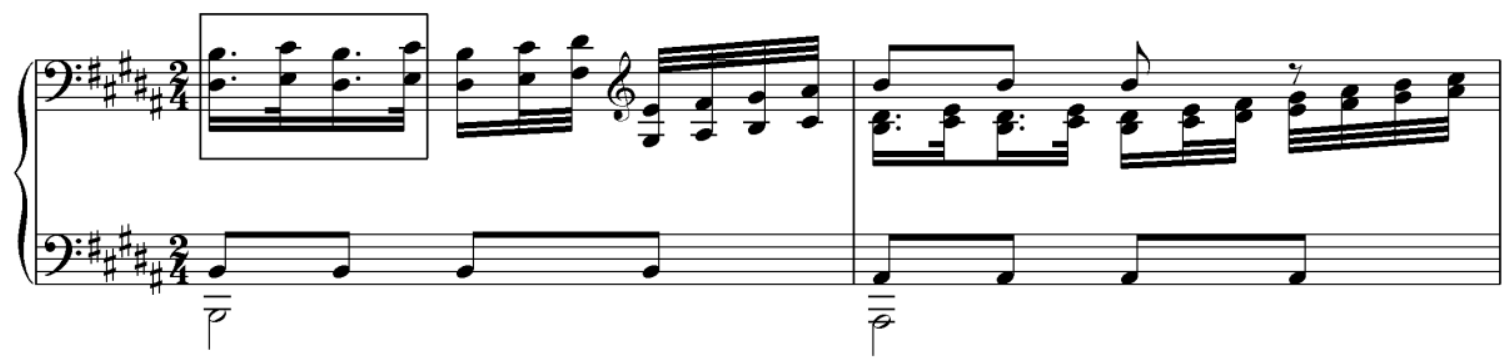

In this transition section, Dussek introduces chromatic notes and unusual harmonies along with successive dotted rhythms. In m. 12, he uses a lowered sixth chord (submediant chord), and adopts it while the B-Major harmonies are presented. He thus uses the lowered-sixth scale degree as a harmonic region within the movement, as well as for its key relative to the overall tonic. 
Example 2A-3 Dussek: "Molto adagio e sostenuto" (mm. 12-13).

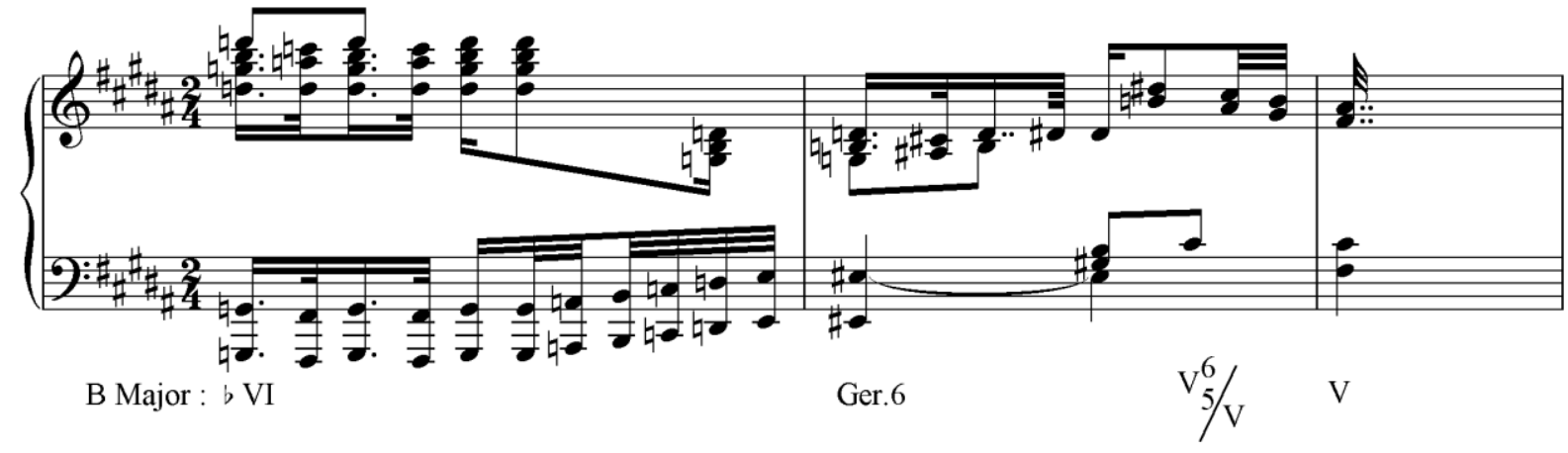

The second part of the transition begins in $\mathrm{m} .18$. The melody of this phrase is based on the first theme's leaping figure in dotted rhythm.

Example 2A-4 Dussek: "Molto adagio e sostenuto" (mm. 18-19. soprano).

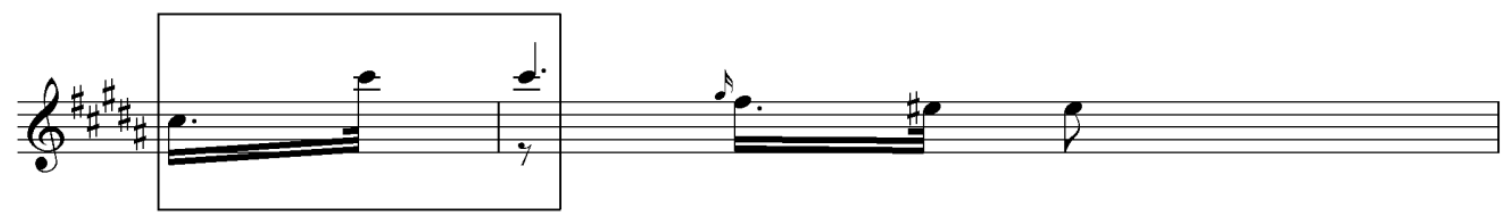

Dussek also employs chromatics within this same rhythmic idea; these will reappear at the end of the transition in the dialogue figure between the soprano and the bass. 
Example 2A-5 Dussek: "Molto adagio e sostenuto" (mm. 21-24, soprano and bass).

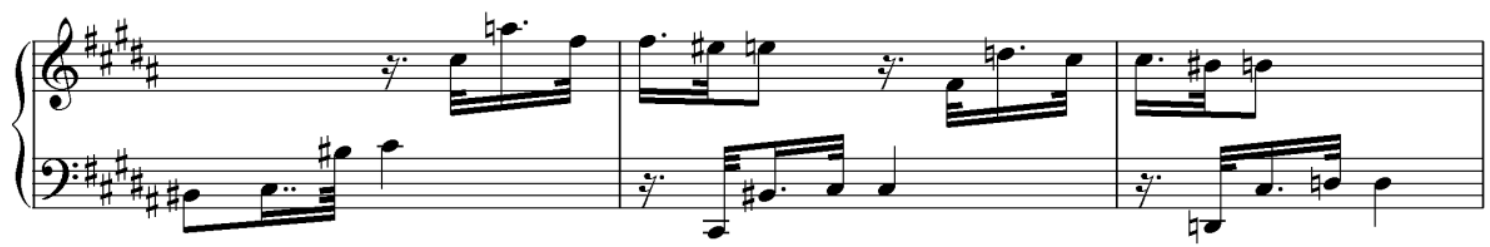

The second theme, in F-sharp Major, the dominant of the original key, bears the musical indication "dolce." The texture of this theme consists of melody and accompaniment, and the characteristic of this theme is moving thirds in the melody as well as the accompaniment section.

Example 2A-6 Dussek: "Molto adagio e sostenuto" (mm. 26-27).

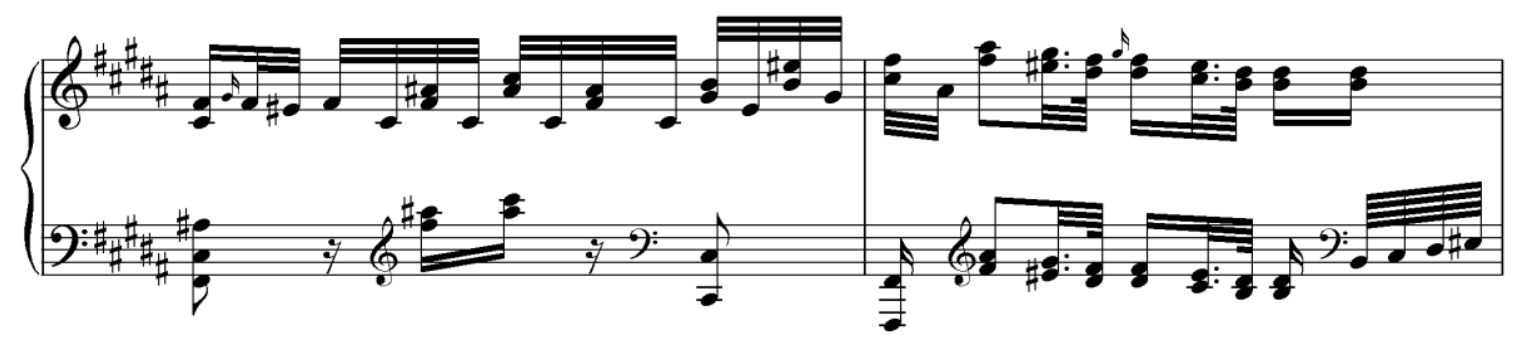

After a repetition of the four-bar second theme, the closing theme appears, also in Fsharp Major. The melody of this theme is placed in an inner voice, supported by a repeated Fsharp pedal tone. 
Example 2A-7 Dussek: "Molto adagio e sostenuto" (mm. 34-35).

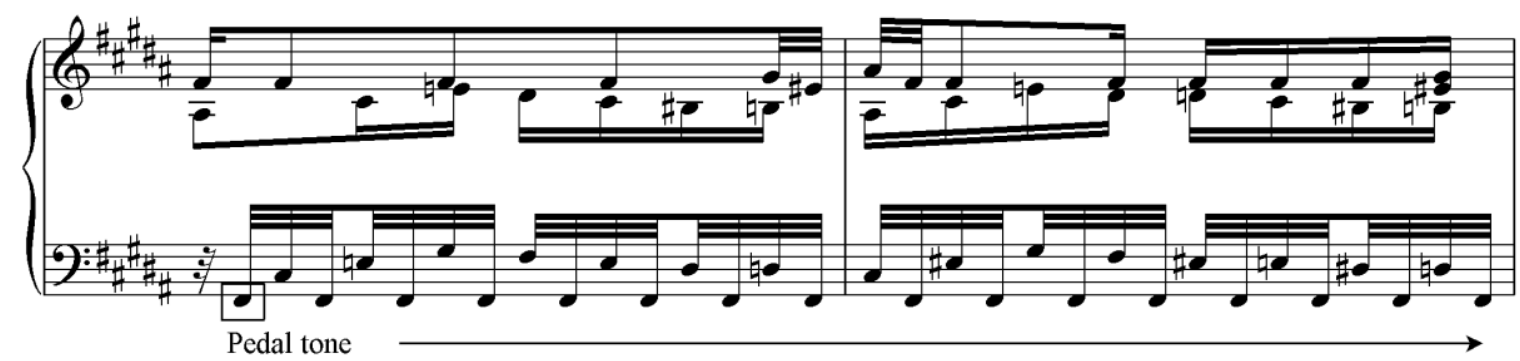

The second movement contains a long development section. This section opens in Fsharp Major, with a fragment of the first theme. The dotted-rhythm figure reappears in this section, here in one-measure fragments.

Example 2A-8 Dussek: "Molto adagio e sostenuto" (m. 38).

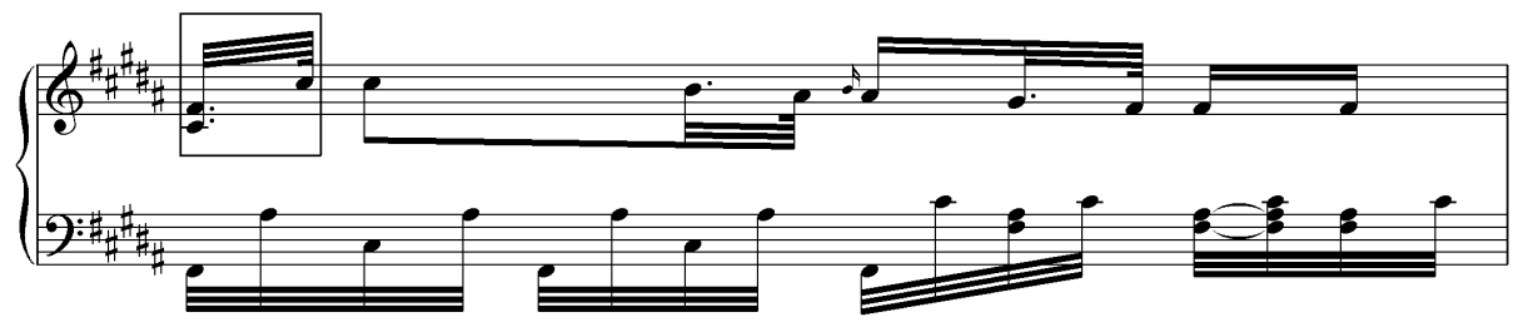

At first, the melody is accompanied by a thirty-second-note figure; these note values subsequently alternate with different accompaniment figures such as thirty-second-note triplets. This development section features a quick tour through several key areas: F-sharp Major, Dsharp minor, F-sharp minor, C-sharp minor, B-flat minor, and so on. The one-measure phrases 
repeat eighteen times in order to reach these different key areas via a sequential pattern. Quick changes in dynamics provide contrast within these repetitions of the material.

Example 2A-9 Dussek: "Molto adagio e sostenuto" (mm. 44-46).

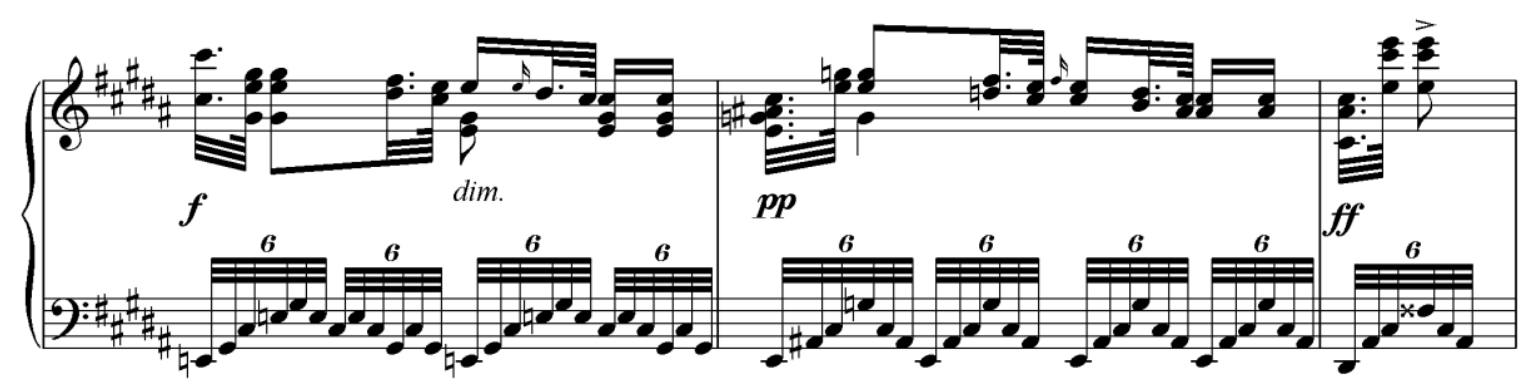

Dussek prepares the return to the exposition with a pedal tone, in the same manner as in the first movement. This pedal tone appears with the marking $s f$ in $\mathrm{m} .57$, and continues until the final measure of the development section. The F-sharp pedal tone plays a significant role, emphasizing the dominant of B Major in order to make a strong resolution at the beginning of the recapitulation. At the end of the development section, the second part of the transition section appears over this sustained pedal tone, leading directly to the recapitulation. 
Example 2A-10 Dussek: "Molto adagio e sostenuto" (mm. 57-58).

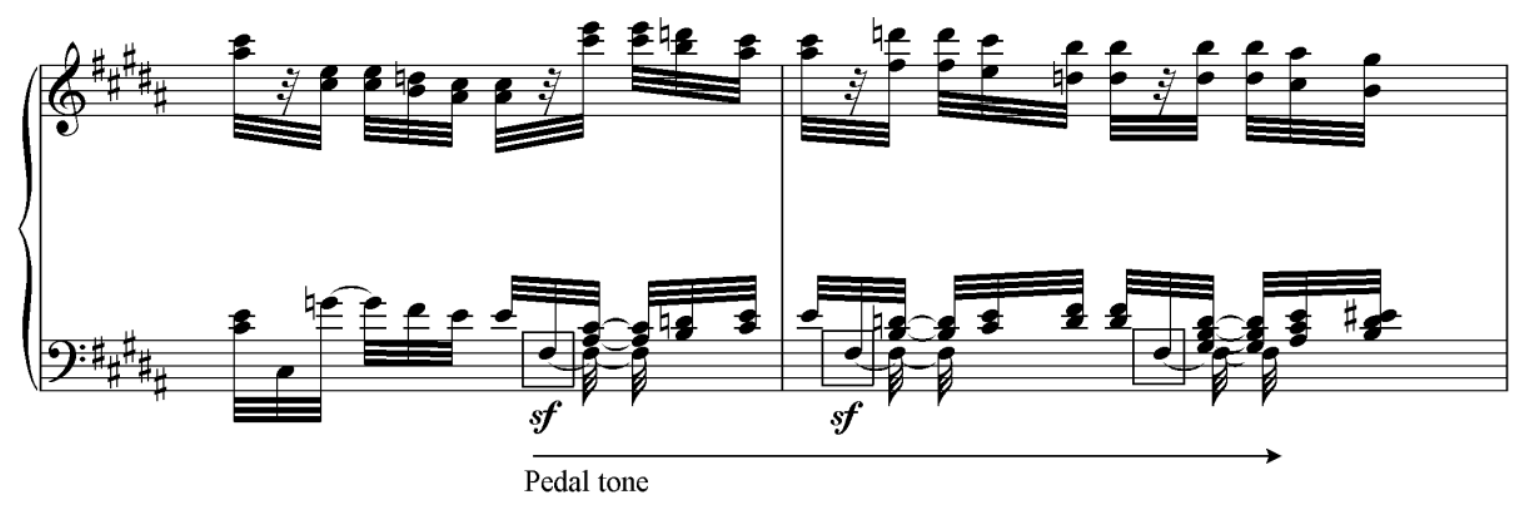

The recapitulation section starts in $\mathrm{m} .68$, and all the themes from the exposition return in the home key of B Major. The formal structure in the recapitulation is very similar to that of the exposition, except for a reversed order and a shortened transition. In the recapitulation, the second theme is placed right after the presentation of the first theme, and the transition section is moved so that it lies between the second theme and the closing theme. Also, the second part of the transition that appeared at the end of the development section is now omitted.

\section{B. Second Movement of Beethoven Sonata in E-flat, Op. 81a}

The second movement of Beethoven's "Farewell" sonata is in binary form. This movement consists of two similar parts ( $\mathrm{A}$ and $\mathrm{A}^{\prime}$ ), and each part contains two contrasting small sections. Detailed sectional components of the movement, including measure number and key information, are presented in the table below. 
Table 2-2 Second movement of Beethoven Sonata in E-flat Major, Op. 81a (Binary Form).

\begin{tabular}{|c|c|c|c|}
\hline \multicolumn{2}{|c|}{ Section } & Measure & Key \\
\hline \multirow{2}{*}{$\mathrm{A}$} & $\mathrm{a}$ & $1-14$ & $\mathrm{c} \rightarrow \mathrm{A} b \rightarrow \mathrm{f} \rightarrow \mathrm{g}$ \\
\cline { 2 - 4 } & $\mathrm{b}$ & $15-20$ & $\mathrm{G} \rightarrow \mathrm{g}$ \\
\hline \multirow{2}{*}{$\mathrm{A}^{\prime}$} & $\mathrm{a}^{\prime}$ & $21-30$ & $\mathrm{f} \rightarrow \mathrm{D} b \rightarrow \mathrm{b} b \rightarrow \mathrm{f}$ \\
\cline { 2 - 4 } & $\mathrm{b}^{\prime}$ & $31-36$ & $\mathrm{~F} \rightarrow \mathrm{f}$ \\
\hline \multicolumn{2}{|c|}{ Codetta } & $37-42$ & $\mathrm{c}(\mathrm{V} 9) \rightarrow \mathrm{E} b$ \\
\hline
\end{tabular}

This second movement begins at a slow tempo in $2 / 4$ meter. Beethoven gives detailed indications at the beginning: "Andante espressivo" and "In gehender Bewegung, doch mit viel Ausdruck [In flowing motion, but with much expression]." In the A section, two contrasting sections ( $a$ and $b$ ) are introduced in different keys. In mm. 1-4, the first thematic section is presented in the key of $\mathrm{C}$ minor, the parallel minor key of the E-flat-Major tonic of the first movement. The main characteristic of this section is a melody in dotted rhythm over a series of five chords that emphasize of the dominant of $\mathrm{C}$ minor. The first chord initially appears to be $\mathrm{C}$ minor; however, that stability vanishes immediately, becoming an intense secondary diminished chord (vii of V) instead of a comfortable tonic. Beethoven repeats this procedure in the second measure. 
Example 2B-1 Beethoven: "Andante espressivo" (second movement) from Sonata in E-flat Major, Op. 81a (mm. 1-4).

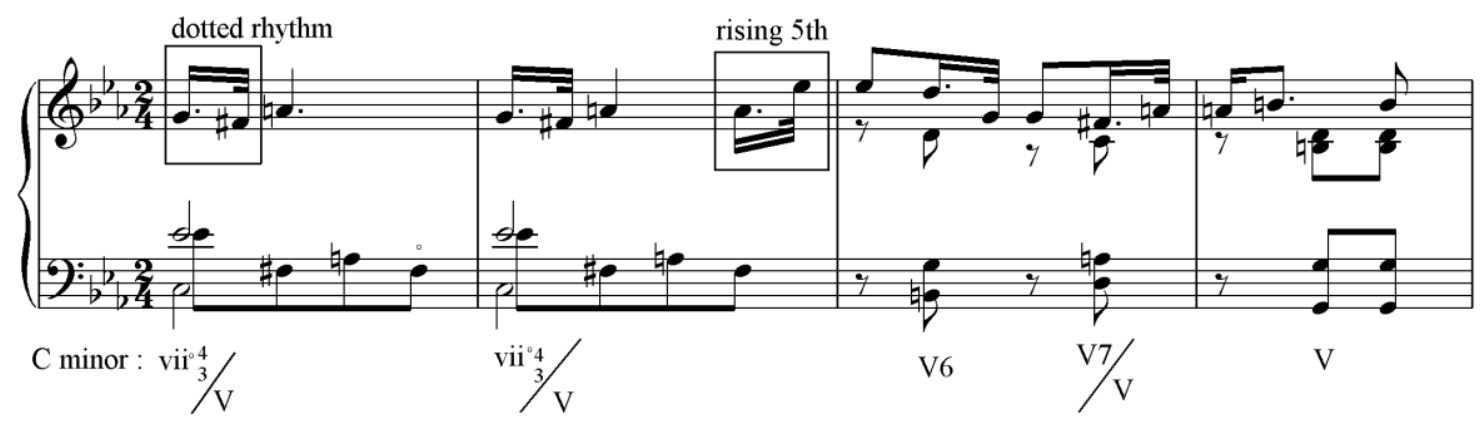

Tovey points out the resemblance between the rising-fifth interval in dotted rhythm, found in the second measure of the second movement, with the rising-fourth pattern in similar rhythm in the second measure of the first movement's introduction (see example 1B-1). ${ }^{118}$

After presenting this opening thematic idea in the first four measures, Beethoven then employs a similar figure presented a minor sixth higher in mm. 5-6, over diminished chords of C minor. Compared with the first eight measures, the music is now more actively expressive, with dramatic dynamic contrasts in mm 9-12. In particular, each of the descending step-wise motions is emphasized with a sforzato in mm. 11-12. The harmonic progression of this first section produces a modulation from $\mathrm{C}$ minor to $\mathrm{G}$ minor, through $\mathrm{A}-$-flat Major and $\mathrm{F}$ minor.

118 Tovey, The Classics of Music, 36. 
Example 2B-2 Beethoven: “Andante espressivo" (mm. 11-12).

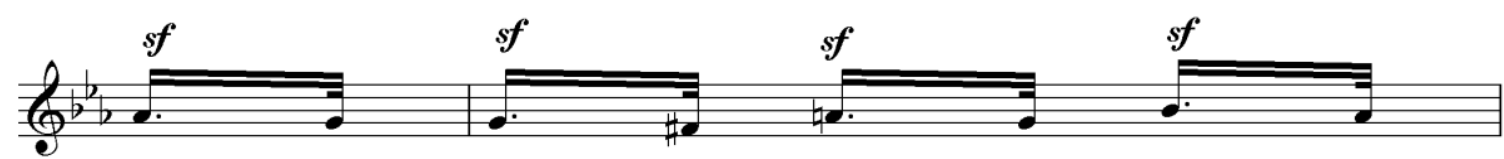

In $\mathrm{m} .15$, the second thematic section begins in G Major, the dominant of the original key. As shown in example 2B-3 below, the main characteristic of this section is a song-like melody that is accompanied by thirty-second notes in a tremolo figure. The melody of this section is made up of two-measure phrases and is embellished with rich ornamentation when it is repeated. This section modulates from G-Major to G minor, and then moves to the $\mathrm{A}^{\prime}$ section.

Example 2B-3 Beethoven: “Andante espressivo" (m. 15).

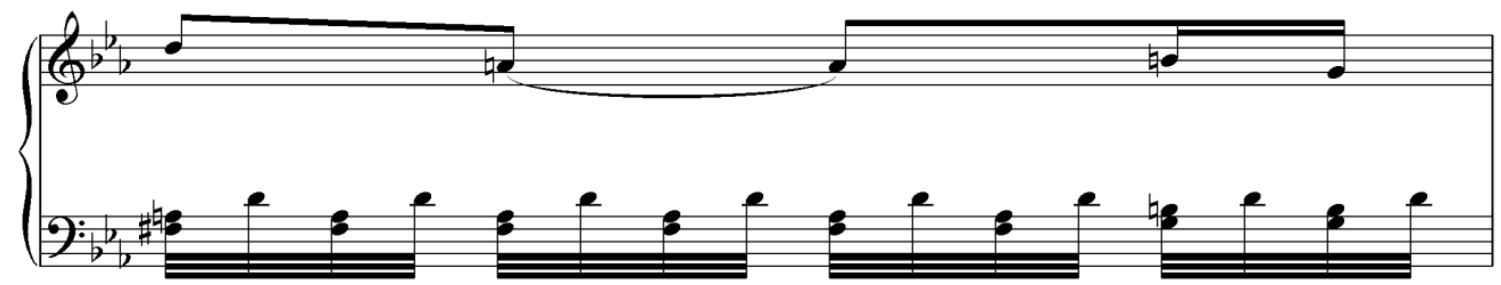

The $\mathrm{A}^{\prime}$ section begins in $\mathrm{m} .21$; while it is similar to the A section, there are several important differences. In contrast with the A section, this new section begins in F minor, modulating through D-flat Major and B-flat minor before it establishes this tonic. The second thematic section initially appears in F Major, before moving to F minor. In addition, the $\mathrm{A}^{\prime}$ 
section is shorter than the A section. After the first four-measure thematic phrase appears, it is not seen again in this section. Finally, as shown in example 2B-4, the melody of the second thematic section is emphasized through octave doublings.

Example 2B-4 Beethoven: “Andante espressivo" (m. 31).

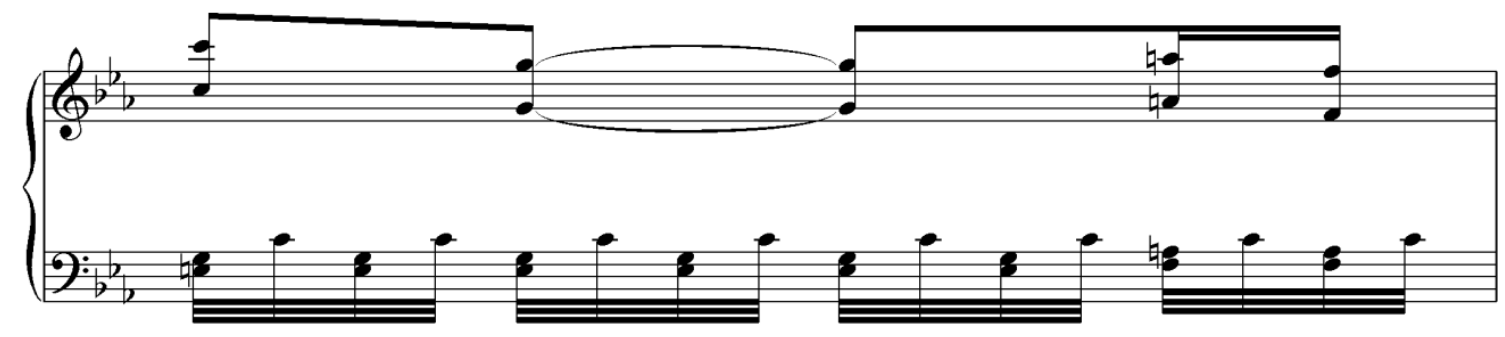

\section{Third Movement of Dussek Sonata in E-flat Major, C. 178}

The third movement of Dussek's "Farewell" sonata is a Minuet and Trio. This is a typical third-movement form for a four-movement sonata. This movement can be divided into four sections: 1) Minuet, 2) Trio, 3) Minuet, and 4) Coda. Detailed sectional components of the movement, including measure number and key information, are presented in the table below. 
Table 3 Third movement of Dussek Sonata in E-flat Major, C. 178 (Menuetto \& Trio).

\begin{tabular}{|c|c|c|c|}
\hline \multicolumn{2}{|c|}{ Section } & Measure & Key \\
\hline \multirow{3}{*}{ Minuet } & A & $1-8$ & $\mathrm{~g} \#$ \\
\cline { 2 - 4 } & $\mathrm{B}$ & $8-24$ & $\mathrm{~g} \#$ \\
\cline { 2 - 4 } & $\mathrm{A}^{\prime}$ & $24-34$ & $\mathrm{~g} \#$ \\
\hline \multirow{3}{*}{ Trio } & $\mathrm{C}$ & $34-50$ & $\mathrm{~A} b$ \\
\cline { 2 - 4 } & $\mathrm{D}$ & $50-66$ & $\mathrm{~A} b$ \\
\hline \multirow{3}{*}{ Minuet } & $\mathrm{C}^{\prime}$ & $66-82$ & $\mathrm{~A} b$ \\
\cline { 2 - 4 } & $\mathrm{A}$ & $82-90$ & $\mathrm{~g} \#$ \\
\cline { 2 - 4 } & $\mathrm{B}$ & $90-106$ & $\mathrm{~g} \#$ \\
\hline & $\mathrm{A}$ & $106-116$ & $\mathrm{~g} \#$ \\
\hline
\end{tabular}

The movement begins in G-sharp minor, the relative minor of the B-Major second movement, and is marked "Tempo di Menuetto più tosto Allegro." The minuet section is mostly composed of syncopated quarter notes in homophonic style and is divided into three parts: A, B, and $\mathrm{A}^{\prime}$. With repeats, these three parts are played in order of $\mathrm{A}-\mathrm{A}-\mathrm{B}-\mathrm{A}^{\prime}-\mathrm{B}-\mathrm{A}^{\prime}$. The eight-measure A section consists of melody and accompaniment with some contrary motion. The melody in mm. 2-3 contains a neighbor-tone figure, which had also appeared in the first movement as a significant element. 
Example 3-1 Dussek: "Tempo di Menuetto più tosto Allegro" (third movement) from Sonata in E-flat Major, C. 178 (mm. 1-4).

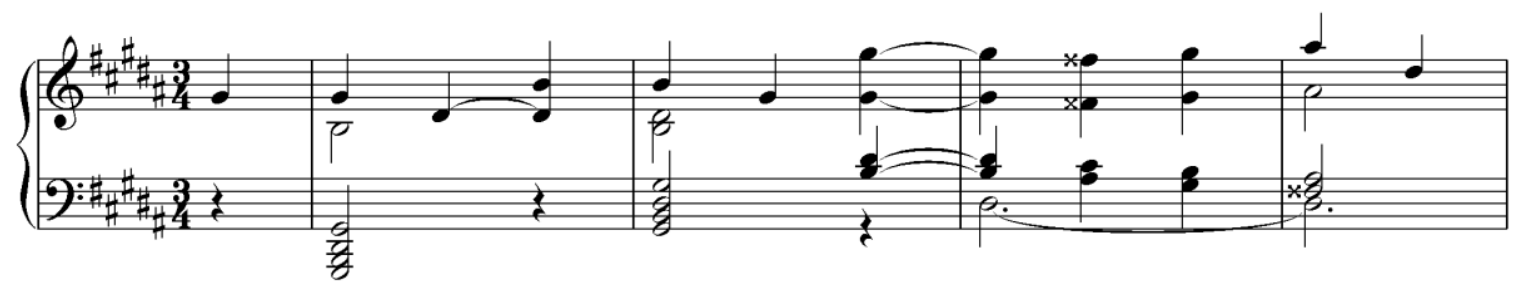

The B part of the minuet section begins in $\mathrm{m} .8$, after the repetition of the A section.

Polyphonic texture dominates this part, along with syncopated rhythms. The opening melody of the left hand is based on the right-hand melody of the previous part (m. 2-3, see example 3-1), and this melody is then extended through the use of sequential motion.

Example 3-2 Dussek: "Tempo di Menuetto più tosto Allegro” (mm. 8-12).

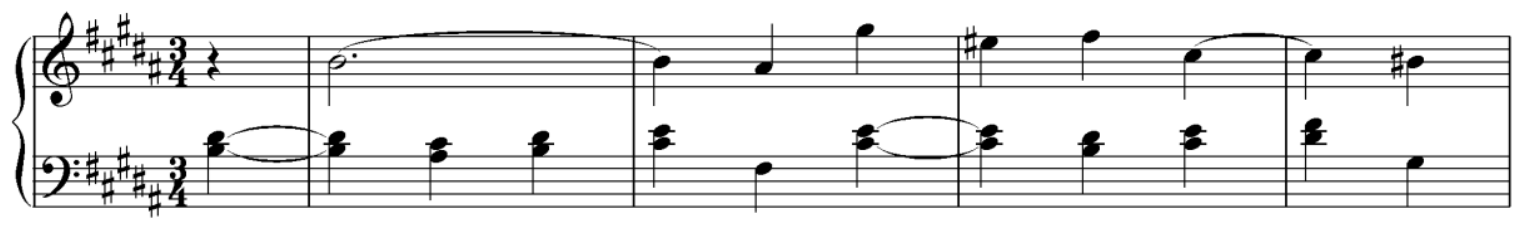

In mm. 17-24, similar melodies with neighbor-tone figures are exchanged between the two hands; they become merged in the $\mathrm{A}^{\prime}$ section. The $\mathrm{A}^{\prime}$ section is the same as the A section except for a two-measure extension at the end. 
Example 3-3 Dussek: "Tempo di Menuetto più tosto Allegro" (mm. 17-22 soprano, tenor, and bass).

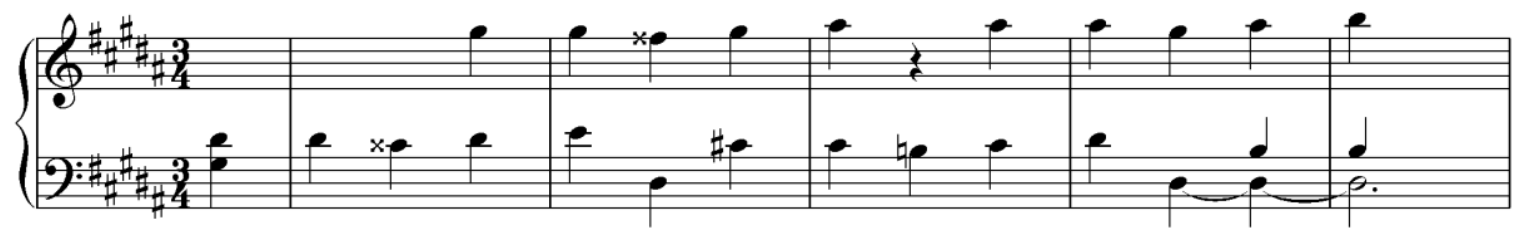

The trio section, in A-flat Major, begins with the musical indication "con molta espressione." This key is the enharmonic equivalent of G-sharp Major, the parallel major of Gsharp minor. This section can be divided into three small parts: C, D, and $\mathrm{C}^{\prime}$. With repeats, these three parts are also played in the order of C-C-D-C-'D-C', which resembles the structure of the minuet section. Syncopations make frequent appearances in the trio section, just as in the minuet section. Fortner mentions this in his dissertation:

"Note that Dussek has carried over the distinctive syncopated rhythm of the minuet into the trio, thereby once again demonstrating that elusive motivic cohesion which, in general, marks his later compositions." 119

The first part of the trio section opens with rhythm similar to mm. 2-6 of the minuet and is followed by a melody combining eighth notes and quarter notes. Dussek employs eighth notes in the trio, in contrast with the quarter notes that dominated the previous section.

119 Fortner, The Piano Sonatas of J. L. Dussek (1760-1812), 117. 
Example 3-4 Dussek: "Tempo di Menuetto più tosto Allegro" (mm. 34-40, soprano).

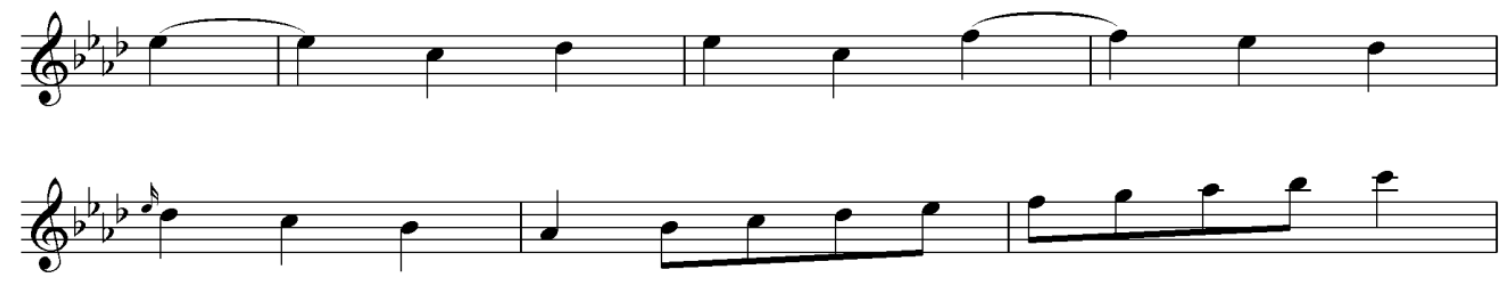

Like the B section of the minuet, the trio's second section is also in polyphonic texture and begins with a left-hand melody. The phrase structure of this part is symmetrical and uses a standard combination of $4+4+8$. Dussek uses sequential motion and reprises the four-measure phrase with alternating melodies between the two hands.

Example 3-5 Dussek: “Tempo di Menuetto più tosto Allegro” (mm. 54-60).
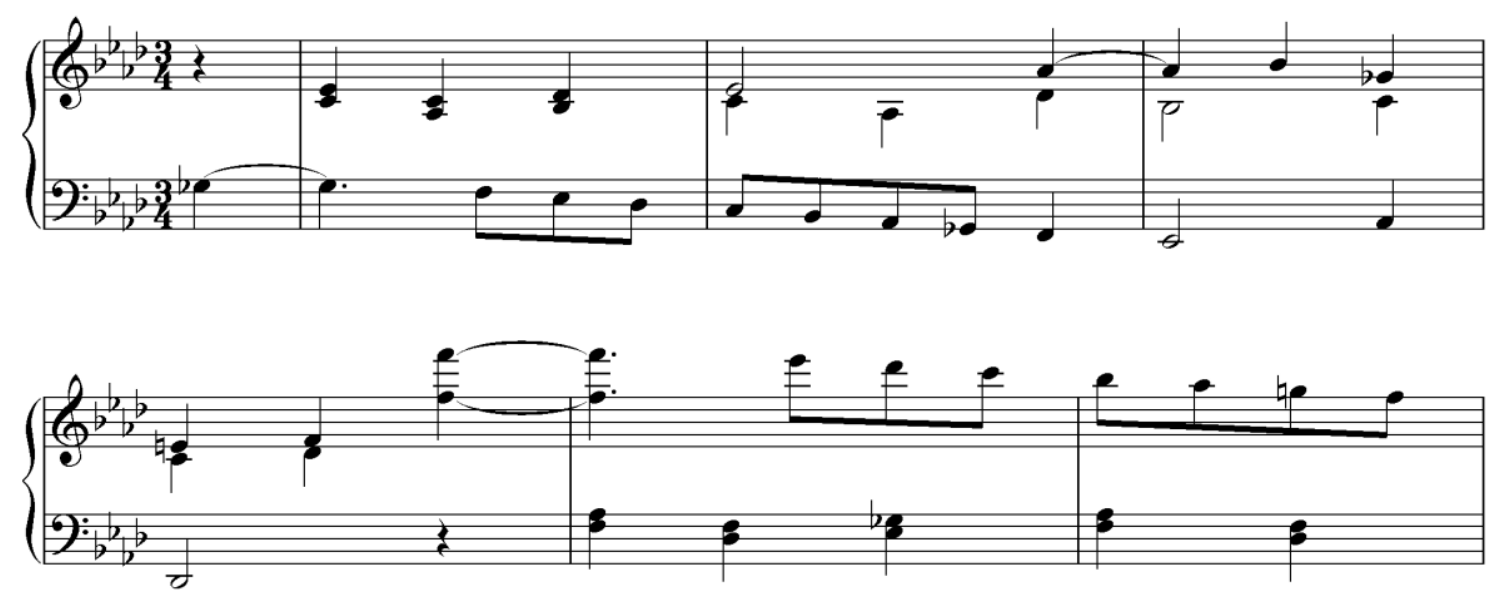
After the trio section, the minuet section returns without repetition, before moving on to a coda section. The coda begins with a motive from the extension in Part $\mathrm{A}^{\prime}$ (mm. 30-32), and the motive recurs many times in sequential motion. This coda section starts in G-sharp minor, but modulates to A-flat Major through its enharmonic equivalent G-sharp Major at the conclusion.

Example 3-6 Dussek: "Tempo di Menuetto più tosto Allegro" (mm. 30-32, right hand, and mm. 116-118, right hand).

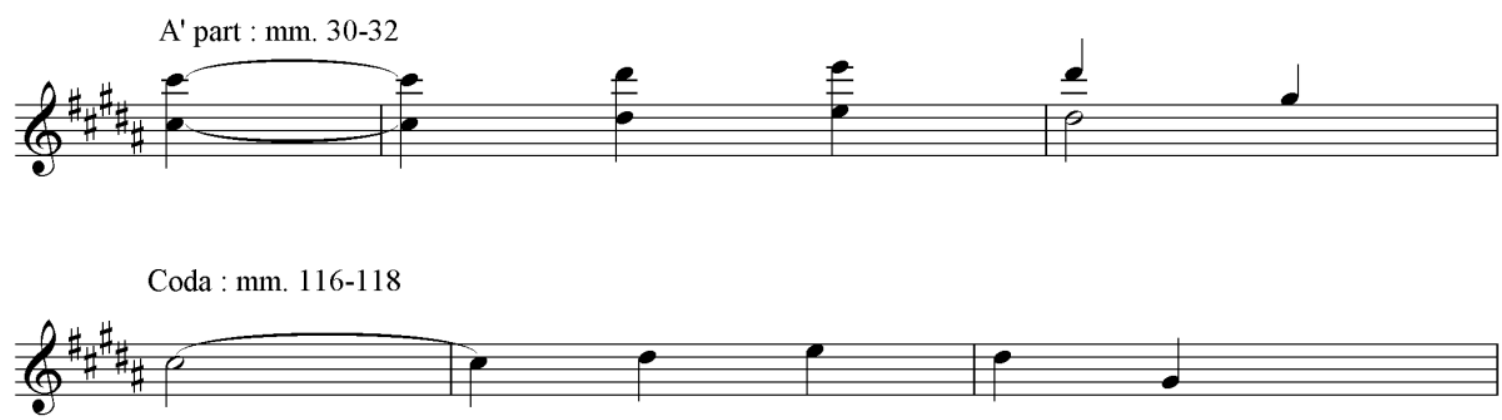

\section{Fourth Movement of Dussek and Third Movement of Beethoven}

\section{A. Fourth Movement of Dussek Sonata in E-flat Major, C. 178:}

Dussek indicates the following marks above the first measure of the fourth movement of his "Farewell" sonata: "Rondo: Allegro moderato ed espressivo." This movement includes six long and complicated structural sections. Detailed sectional components of the movement, including measure number and key information, appear in the three tables below, illustrating several possible ways to view the overall structure of this movement. 
Table 4-1a Fourth movement of Dussek Sonata in E-flat Major, C. 178: "Rondo: Allegro moderato ed espressivo." This view of the movement suggests Variation form.

\begin{tabular}{|c|c|c|c|}
\hline \multicolumn{2}{|c|}{ Section } & Measure & Key \\
\hline \multirow{2}{*}{ A } & $\mathrm{a}$ & $1-20$ & $\mathrm{~Eb}$ \\
\hline & $\mathrm{b}$ & $20-43$ & $\mathrm{~Eb}$ \\
\hline \multirow{7}{*}{$\mathrm{A}^{\prime}$} & $\mathrm{a}$ & $44-63$ & $\mathrm{~Eb}$ \\
\hline & $\mathrm{c}$ & $63-83$ & $\mathrm{~Eb}$ \\
\hline & $\mathrm{d}$ & 84-107 & $\begin{array}{c}\mathrm{B} b \rightarrow \mathrm{b} b \rightarrow \mathrm{a} b \rightarrow \mathrm{b} b \\
\rightarrow \mathrm{B} b\end{array}$ \\
\hline & $b^{\prime}$ & $108-129$ & $\mathrm{~B} b$ \\
\hline & $\mathrm{e}$ & $130-145$ & $\mathrm{Bb}$ \\
\hline & $a^{\prime}$ & $146-157$ & $\mathrm{Bb}$ \\
\hline & $\mathrm{d}^{\prime}$ & $158-175$ & $\mathrm{~B} b$ \\
\hline \multirow[b]{2}{*}{$A^{\prime \prime}$} & $\mathrm{a}$ & 176-195 & $\mathrm{E} b$ \\
\hline & $a^{\prime \prime}$ & $195-253$ & $\begin{array}{c}\mathrm{c} \rightarrow \mathrm{g} \rightarrow \mathrm{c} \rightarrow \mathrm{f} \rightarrow \mathrm{b} b \rightarrow \\
\mathrm{B} b \rightarrow \mathrm{Eb}\end{array}$ \\
\hline \multirow{2}{*}{$\mathrm{A}^{\prime \prime \prime}$} & $\mathrm{a}^{\prime \prime \prime}$ & $254-273$ & $\mathrm{~Eb}$ \\
\hline & $b^{\prime \prime}$ & $273-302$ & $\mathrm{~Eb}$ \\
\hline$A^{\prime \prime \prime \prime \prime}$ & $a^{\prime \prime \prime \prime}$ & $303-346$ & $\mathrm{~Eb}$ \\
\hline \multicolumn{2}{|c|}{ Coda } & $347-391$ & $\mathrm{~Eb}$ \\
\hline
\end{tabular}


Table 4-1b Fourth movement of Dussek Sonata in E-flat Major, C. 178: "Rondo: Allegro moderato ed espressivo." This view of the movement suggests Rondo form.

\begin{tabular}{|c|c|c|c|}
\hline \multicolumn{2}{|c|}{ Section } & Measure & Key \\
\hline \multirow{5}{*}{ A } & $\mathrm{a}$ & $1-20$ & $\mathrm{~Eb}$ \\
\hline & $\mathrm{b}$ & $20-43$ & $\mathrm{~Eb}$ \\
\hline & $\mathrm{a}$ & $44-63$ & $\mathrm{~Eb}$ \\
\hline & $\mathrm{c}$ & $63-83$ & $\mathrm{~Eb}$ \\
\hline & $\mathrm{d}$ & 84-107 & $\begin{array}{c}\mathrm{B} b \rightarrow \mathrm{b} b \rightarrow \mathrm{a} b \rightarrow \mathrm{b} b \\
\rightarrow \mathrm{B} b\end{array}$ \\
\hline \multirow{4}{*}{ B } & $b^{\prime}$ & $108-129$ & $\mathrm{~B} b$ \\
\hline & e & $130-145$ & $\mathrm{Bb}$ \\
\hline & $a^{\prime}$ & $146-157$ & $\mathrm{Bb}$ \\
\hline & $\mathrm{d}^{\prime}$ & $158-175$ & $\mathrm{~B} b$ \\
\hline A & $\mathrm{a}$ & 176-195 & $\mathrm{E} b$ \\
\hline $\mathrm{C}$ & $a^{\prime \prime}$ & $195-253$ & $\begin{array}{c}\mathrm{c} \rightarrow \mathrm{g} \rightarrow \mathrm{c} \rightarrow \mathrm{f} \rightarrow \mathrm{b} b \rightarrow \\
\mathrm{B} b \rightarrow \mathrm{E} b\end{array}$ \\
\hline \multirow{3}{*}{ A } & $\mathrm{a}^{\prime \prime \prime}$ & $254-273$ & $\mathrm{~Eb}$ \\
\hline & $b^{\prime \prime}$ & $273-302$ & $\mathrm{~Eb}$ \\
\hline & $a^{\prime \prime \prime \prime}$ & $303-346$ & $\mathrm{~Eb}$ \\
\hline \multicolumn{2}{|c|}{ Coda } & $347-391$ & $\mathrm{~Eb}$ \\
\hline
\end{tabular}


Table 4-1c Fourth movement of Dussek Sonata in E-flat Major, C. 178: "Rondo: Allegro moderato ed espressivo." This view of the movement suggests Sonata-Rondo form.

\begin{tabular}{|c|c|c|c|}
\hline \multicolumn{2}{|c|}{ Section } & Measure & Key \\
\hline \multirow{3}{*}{ A } & $\mathrm{a}$ & $1-20$ & $\mathrm{~Eb}$ \\
\hline & $\mathrm{b}$ & $20-43$ & $\mathrm{E} b$ \\
\hline & $\mathrm{a}$ & $44-63$ & $\mathrm{~Eb}$ \\
\hline \multirow[b]{2}{*}{ Transition } & $\mathrm{c}$ & $63-83$ & $\mathrm{~Eb}$ \\
\hline & d & 84-107 & $\begin{aligned} & \mathrm{B} b \rightarrow \mathrm{b} b \rightarrow \mathrm{a} b \rightarrow \mathrm{b} b \\
& \rightarrow \mathrm{B} b\end{aligned}$ \\
\hline \multirow{4}{*}{ B } & $b^{\prime}$ & $108-129$ & $\mathrm{~B} b$ \\
\hline & $\mathrm{e}$ & $130-145$ & $\mathrm{Bb}$ \\
\hline & $a^{\prime}$ & $146-157$ & $\mathrm{~B} b$ \\
\hline & $d^{\prime}$ & $158-175$ & $\mathrm{Bb}$ \\
\hline A & $\mathrm{a}$ & $176-195$ & $\mathrm{~Eb}$ \\
\hline $\mathrm{C}$ & $a^{\prime \prime}$ & $195-253$ & $\begin{array}{c}\mathrm{c} \rightarrow \mathrm{g} \rightarrow \mathrm{c} \rightarrow \mathrm{f} \rightarrow \mathrm{b} b \rightarrow \\
\mathrm{B} b \rightarrow \mathrm{Eb}\end{array}$ \\
\hline \multirow{3}{*}{ A } & $\mathrm{a}$ & $254-273$ & $\mathrm{~Eb}$ \\
\hline & $\mathrm{b}$ & $273-302$ & $\mathrm{~Eb}$ \\
\hline & $\mathrm{a}^{\prime \prime \prime}$ & $303-310$ & $\mathrm{~Eb}$ \\
\hline $\mathrm{B}^{\prime}$ & $a^{\prime \prime \prime \prime}$ & $311-346$ & $\mathrm{E} b$ \\
\hline A & $a^{\prime \prime \prime \prime \prime}$ & $347-391$ & $\mathrm{~Eb}$ \\
\hline
\end{tabular}

Composers have frequently employed the rondo form for sonata finales. The Harvard

Dictionary of Music defines rondo as a form where:

"...the principal theme or section (usually symbolized A), known also as the refrain or rondo, alternates with subsidiary sections called couplets or episodes (symbolized B, C, etc.); it then returns at or near the end to complete the movement. All statements of the refrain are normally in the tonic key, whereas the couplets or episodes favor contrasting tonalities." 120

120 Don Michael Randel, The Harvard Dictionary of Music, 741-742. 
The usual form of a rondo consists of A-B-A-C-A or A-B-A-C-A-B-A. There is one element that follows a typical rondo format (A-B-A-C-A) in this movement: the sequence of tonalities. Dussek begins this movement in E-flat Major, and modulates to B-flat Major in m. 84 . The music then returns to E-flat Major, moves to a complex tonal area starting in $\mathrm{C}$ minor in $\mathrm{m}$. 195, and finally comes back to E-flat Major again. This is perfectly in keeping with the standard major-key rondo pattern: A (I) - B (V) - A (I) - C (complex tonal areas) - A (I).

Grossman mentions the form of this movement in his dissertation:

"A few rondos employ the sonata-rondo scheme, A-B-A-C-A-B'-A.... The final movements of Op. 44 and Op. 61 (C. 211) are sonata-rondos, and the greater complexity of design mirrors the more elaborate harmonies and textures which these movements exhibit." ${ }^{\prime 21}$

Although he does not provide specific examples to support this opinion, the basic harmonic structure of conventional sonata rondo form is tonic-dominant-tonic $(\mathrm{E} b-\mathrm{B} b-\mathrm{E} b)$. This movement begins in E-flat Major, and the second key area is presented in $\mathrm{m} .108$ following a short transition. The A section returns in E-flat Major in m. 254, and the B section also returns in this key in $\mathrm{m} .311$, with complex textures. The C section, mm. 195-253, contains various modulations, including elaborate textures based on materials from the A and B sections.

However, this movement differs from the traditional rondo in its construction and organization. This movement follows the pattern A- A'- A"- $\mathrm{A}^{\prime \prime \prime}-\mathrm{A}^{\prime \prime \prime \prime}-\mathrm{Coda}$; its repeated statements of the same material strongly suggest variation technique.

This movement bears the tempo indication "Allegro moderato ed espressivo." Its opening material establishes the tonic of E-flat Major, the home key of the entire sonata. The A

121 Grossman, The Piano Sonatas of Jan Ludislav Dussek (1760-1812), 19. 
section mostly consists of syncopated rhythmic figures with suspensions and is divided into two parts, here designated (a) and (b). The (a) part of the A section opens with a descending step-wise figure, starting with G-F-E $b$, along with an ascending step-wise figure in thirds in the left hand. The phrase structure of the twenty-measure (a) part is asymmetric and uses an unusual combination of $4+4+8+4$.

Example 4A-1 Dussek: "Allegro moderato ed espressivo" (fourth movement) from Sonata in Eflat Major, C. 178 (mm. 1-4, in (a) part of section A).

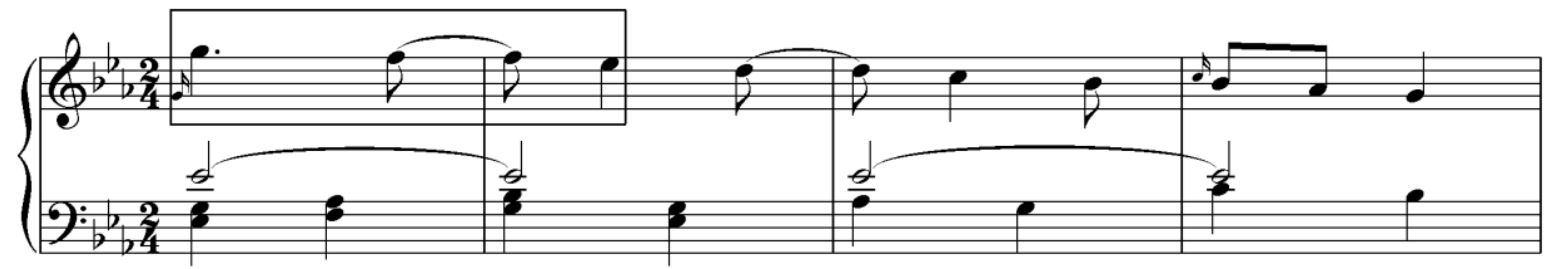

The (b) part begins in m. 20 with the dominant-seventh chord of E-flat Major. The (b) part is based on the (a) part, with the descending step-wise figure and accompaniment pattern at the beginning (see example 4A-1). To create the melody in this section, Dussek combines the basic element of (a) with new materials, such as ascending-third step-wise figures with eighthnote and sixteenth-note rhythms in the melody, and eighth-note figures at the end of the accompaniment part. 
Example 4A-2 Dussek: "Allegro moderato ed espressivo" (mm. 20-24, in part (b) of section A).

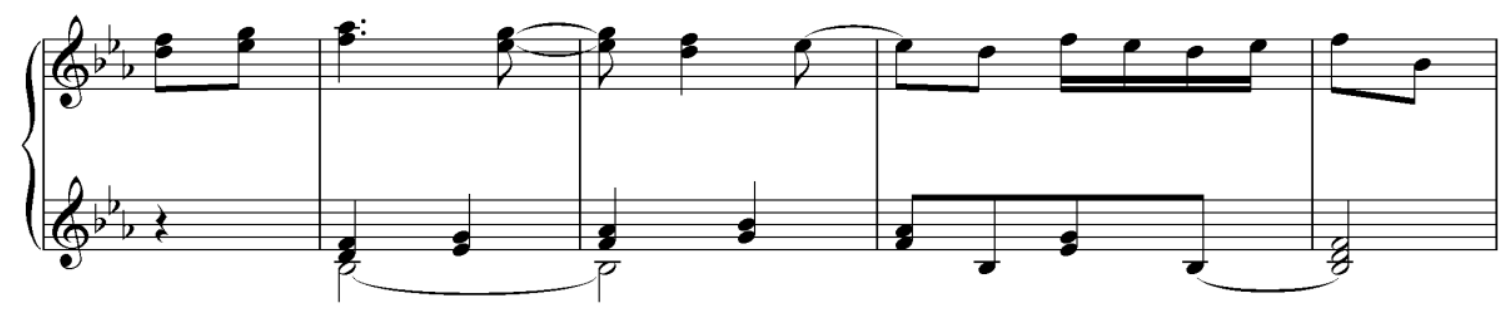

Interestingly, the horn-fifth motive that Beethoven would use in the first movement of his "Farewell" sonata, known as the 'Lebewohl' motive, appears here in retrograde order in the left hand in mm. 25-26 (see example 1A-1).

Example 4A-3 Dussek: "Allegro moderato ed espressivo" (mm. 25-26, in part (b) of section A).

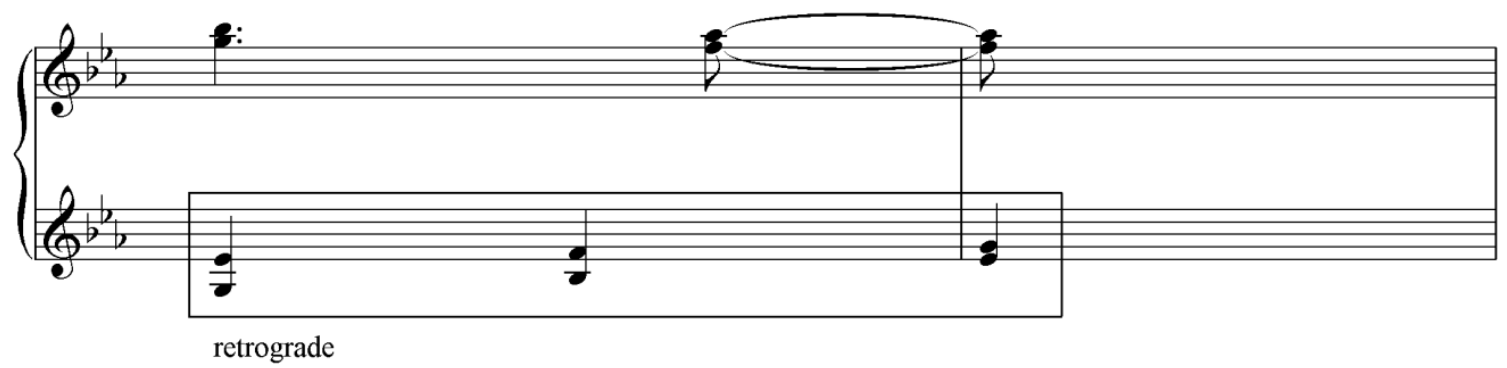

Dussek often uses a borrowed chord. In $\mathrm{m} 35$, he uses a tonic minor, and adapts it to the surrounding E-flat Major harmonies. He thus uses the lowered-third scale degree as a harmonic region within the movement. 
Example 4A-4 Dussek: "Allegro moderato ed espressivo" (mm. 34-35, in part (b) of section A).

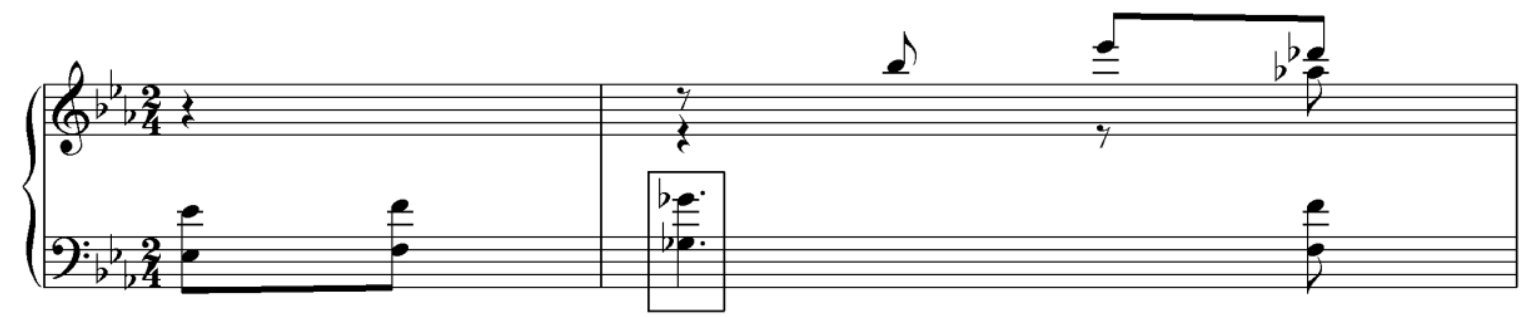

The $\mathrm{A}^{\prime}$ section begins with the opening part (a) of this movement, and brings in new material. The $\mathrm{A}^{\prime}$ section can be divided into seven parts. After the (a) part, the (c) part begins with new material in $\mathrm{m} .63$. In this passage, rapid running sixteenth notes dominate in arpeggiated figurations, in contrast with the quarter notes and eighth notes that governed the previous sections. The texture of the (c) section is polyphonic, with different melodies appearing in both hands.

Example 4A-5 Dussek: "Allegro moderato ed espressivo" (mm. 63-65, in part (c) of section A').

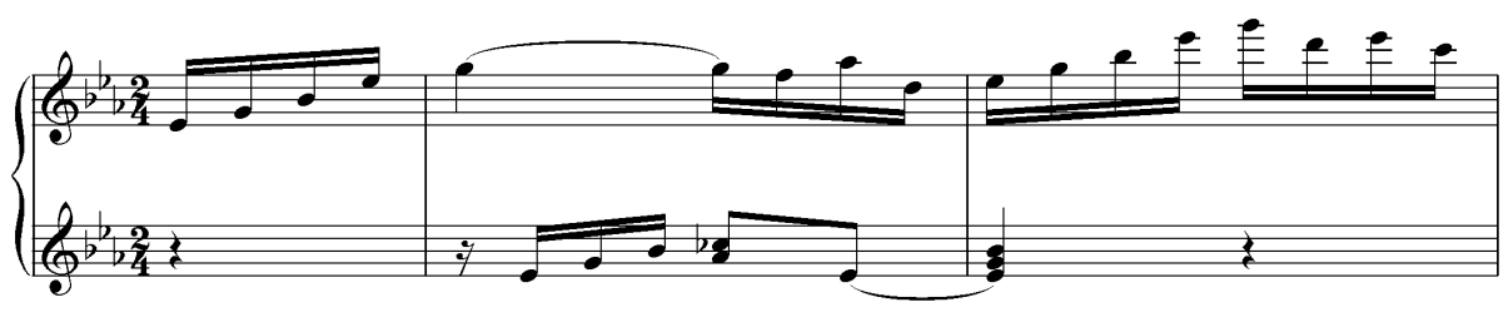


The (d) part is presented in B-flat Major, the dominant key of this movement, in m. 84. This section returns to a more straightforward texture of melody and accompaniment, with the melody consisting of rapid running sixteenth notes in arpeggios. After four measures, the music undergoes a mode change to B-flat minor in $\mathrm{m} .88$, after which a diminished-chord progression appears and continues with two-measure sequential phrases, along with chromatic step-wise descending motion in the bass in mm. 90-94. In addition, in mm. 94-97, a one-measure sequential pattern, reduced in size, effects a modulation from B-flat minor to A-flat minor, through the secondary diminished seventh of IV and a German augmented-sixth chord. After that the key returns to B-flat minor in $\mathrm{m} .98$. 
Example 4A-6 Dussek: "Allegro moderato ed espressivo" (mm. 84-85 \& 94-97, in part (d) of section $\mathrm{A}^{\prime}$ ).
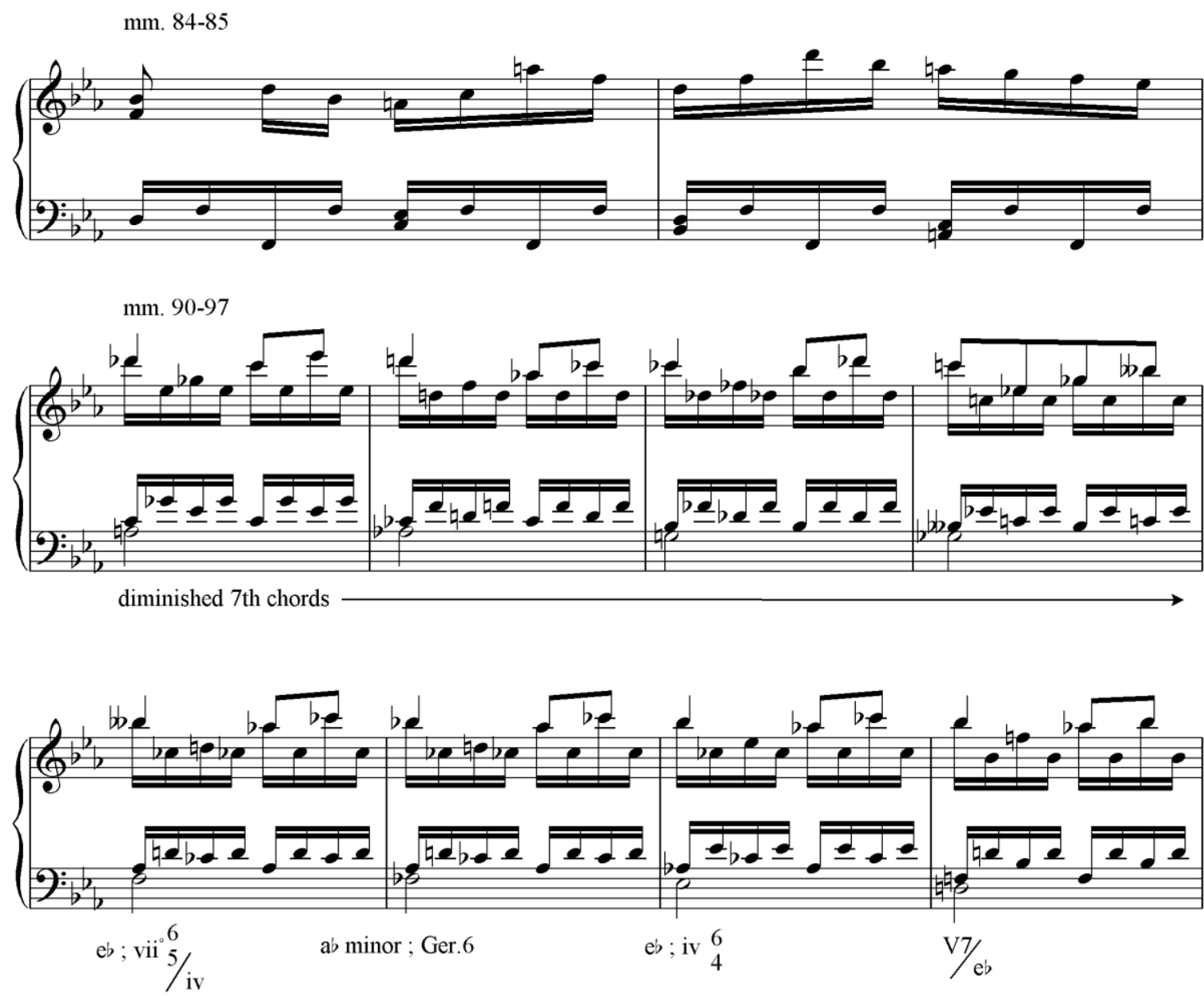

The $\left(b^{\prime}\right)$ part begins in $\mathrm{m} .108$ with material from the $(b)$ part over a subdominant chord of B-flat Major in first inversion (see example 4A-2). The material is presented with eighth-note accompaniment in $\mathrm{m} .111-115$, after which a fragment of the material is reprised and developed in different registers with sequential motion in mm.115-118. 
Example 4A-7 Dussek: "Allegro moderato ed espressivo" (mm. 108-113, in part (b') of section $\left.\mathrm{A}^{\prime}\right)$.

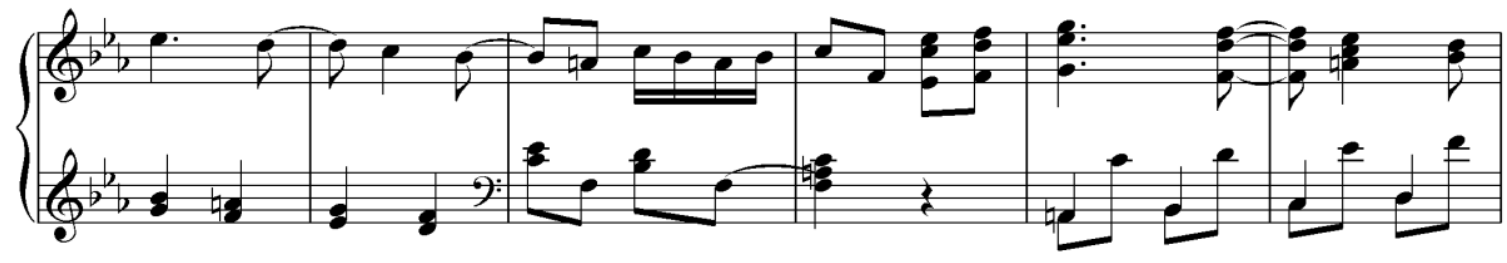

The (e) part opens in m. 130 with a homophonic texture - a melody and accompaniment pattern in B-flat Major. The melody of this part features a persistent use of the rhythm ( $\cdot$ ), which first appeared at the beginning of the (d) part (see example 4A-6), and which is accompanied here by quarter notes in the left hand.

Example 4A-8 Dussek: "Allegro moderato ed espressivo" (mm. 130-131, in part (e) of section $\left.\mathrm{A}^{\prime}\right)$.

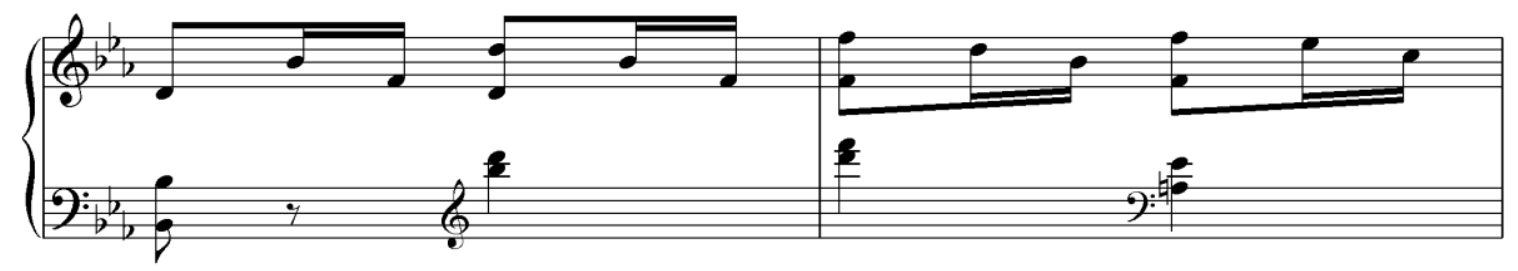

In $\mathrm{m} .146$, the $\left(\mathrm{a}^{\prime}\right)$ part is presented in homophonic texture, over a second inversion of the dominant seventh of $\mathrm{V}$ in B-flat Major. The melody of this part is based on the melody of part (a), but the accompaniment pattern is different from that of the (a) part. In this section, sixteenth 
notes are used for the accompaniment material, whereas quarter notes predominate in the (a) part. After the melody is stated once, it is extended with a fragment of this part's melody.

Example 4A-9 Dussek: "Allegro moderato ed espressivo" (mm. 146-149, in part (a') of section $\left.\mathrm{A}^{\prime}\right)$.

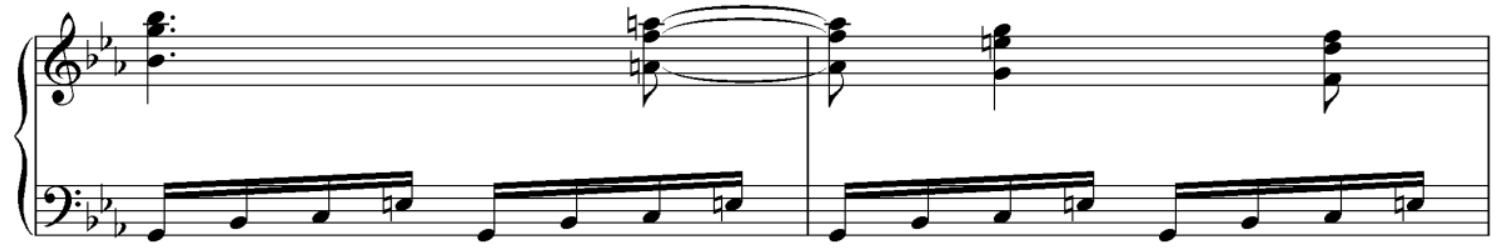

After the $\left(a^{\prime}\right)$ part, the whole $A^{\prime}$ section concludes with the $\left(d^{\prime}\right)$ part. This section begins in B-flat Major in m. 158, and the opening is very similar to the (d) part except for the accompaniment pattern, which uses eighth notes (see example 4A-6).

Example 4A-10 Dussek: "Allegro moderato ed espressivo" (mm. 158-159, in part (d') of section $\left.\mathrm{A}^{\prime}\right)$.

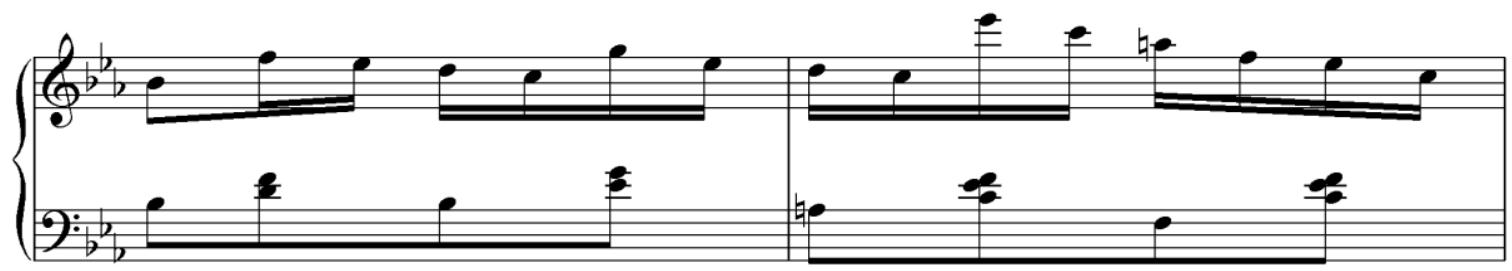

The $A^{\prime \prime}$ section contains two small parts: (a) and $\left(a^{\prime \prime}\right)$. This section opens with a reappearance of the principal section (a) in $\mathrm{m} .176$, and then presents the ( $\left.\mathrm{a}^{\prime \prime}\right)$ part in $\mathrm{m}$. 195. The 
opening melody of the $\left(\mathrm{a}^{\prime \prime}\right)$ part combines two elements, taken from the (a) and (b) parts of the A section. The melody begins with the rising-third step-wise motion of the (b) part with octave doublings (see example 4A-2) and then employs the descending step-wise figure of the (a) part (see example 4A-1). However, the (b) material appears only once at the beginning of this section, while the basic melody and rhythm of the (a) part dominate. This part also closely resembles the (a') material, especially in the accompaniment figures (see example 4A-9).

Example 4A-11 Dussek: "Allegro moderato ed espressivo" (mm. 195-199, in part (a") of section $\left.A^{\prime \prime}\right)$.

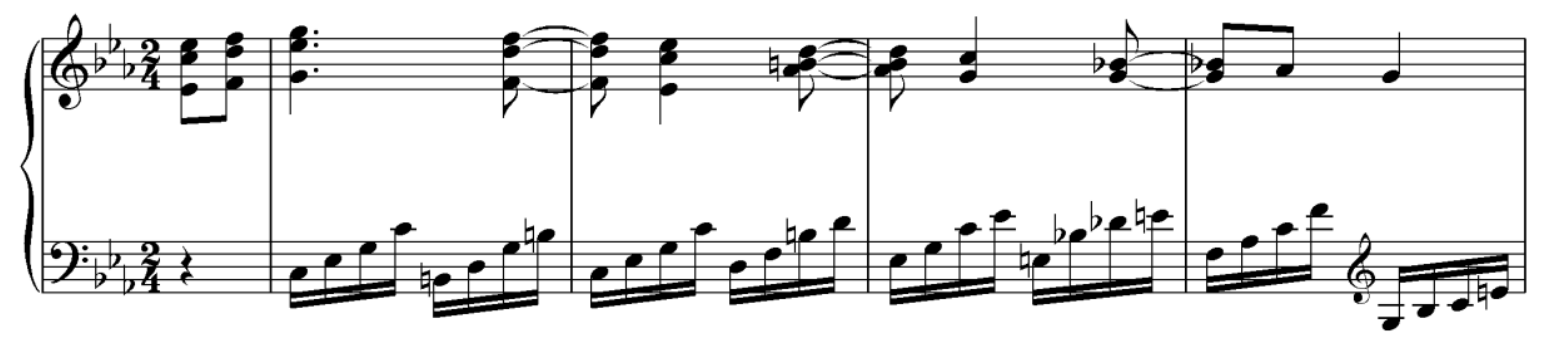

In the entire $\left(\mathrm{a}^{\prime \prime}\right)$ part, the melody, based on the principal (a) part, is reprised many times in various guises, alternating between hands. Example 4A-12 shows one example of a varied melody. This repetition continues while the key area begins to change. The ( $\left.\mathrm{a}^{\prime \prime}\right)$ part begins in $\mathrm{C}$ minor and modulates to E-flat Major through $\mathrm{G}$ minor (m. 204), C minor (m. 220), F minor (m. 224), B-flat minor (m. 236), and B-flat Major (m. 242). 
Example 4A-12 Dussek: "Allegro moderato ed espressivo" (mm. 200-203, in part (a") of section $\left.\mathrm{A}^{\prime \prime}\right)$.

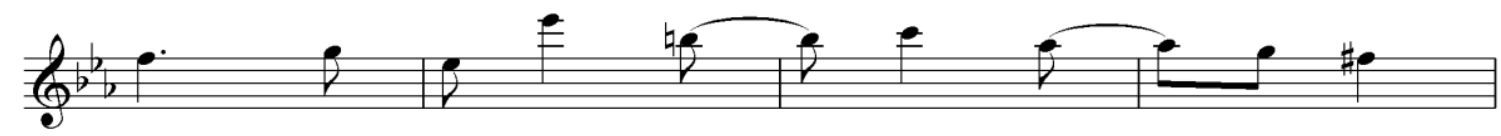

The $\mathrm{A}^{\prime \prime \prime}$ section starts in $\mathrm{m} .254$, and the (a) part and ( $\left.\mathrm{b}^{\prime \prime}\right)$ part are reprised in E-flat

Major. Every musical element in this A"' section is very similar to the A section (see examples 4A-1 and 4A-2), except for a longer second part ( $\left.b^{\prime \prime}\right)$, which is extended by several measures.

Example 4A-13 Dussek: "Allegro moderato ed espressivo" (mm. 254-257 \& 273-277, in part $\left(a^{\prime \prime \prime}\right)$ and $\left(b^{\prime \prime}\right)$ of section $\left.A^{\prime \prime \prime}\right)$.
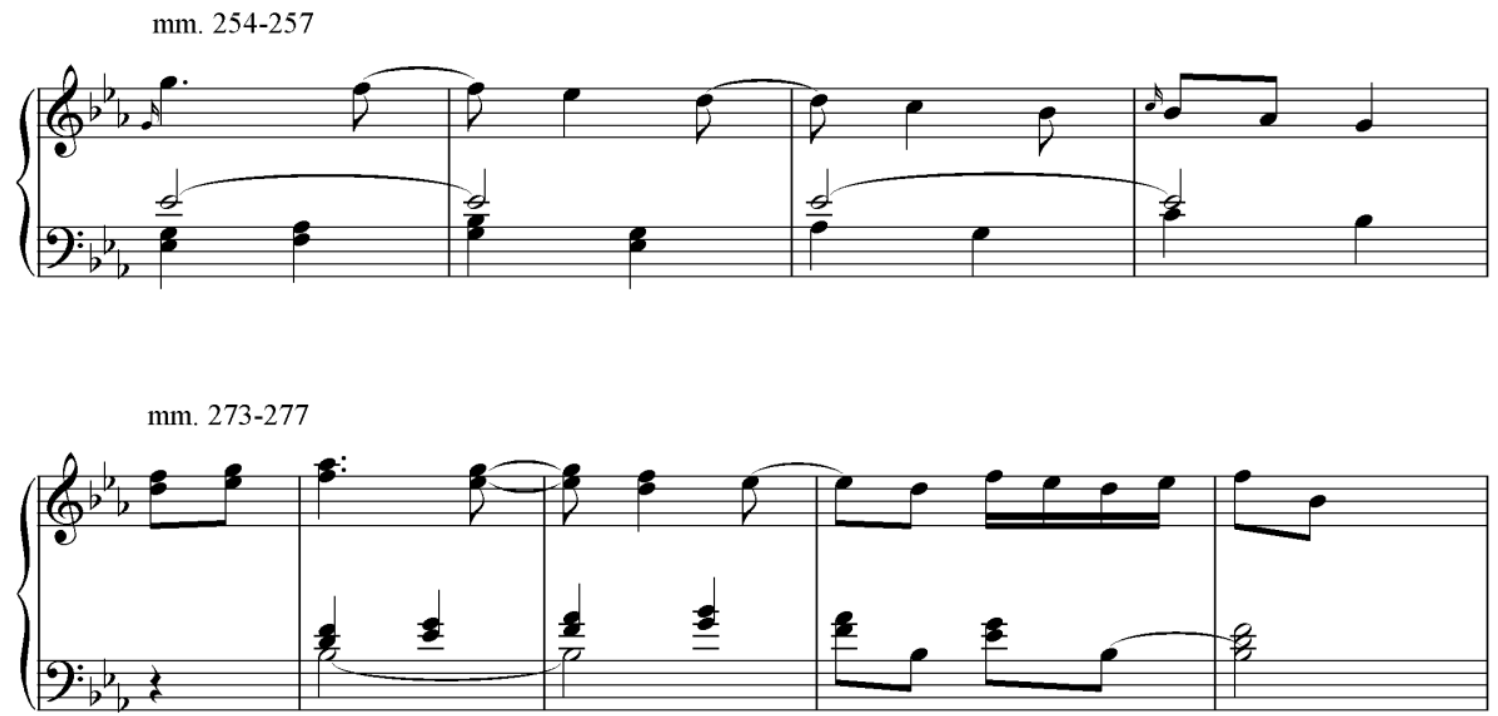
The $\mathrm{A}^{\prime \prime \prime \prime}$ section starts with the beginning of the (a) part in $\mathrm{m}$. 303. This material employs three different textures: homophony, monophony, and polyphony. In m. 311, a gesture similar to the (a') part appears (see example 4A-9) in polyphonic texture. In mm. 329-332, monophonic texture makes a sudden appearance. Sixteenth-note scales in E-flat Major are presented in both hands. This $\mathrm{A}^{\prime \prime \prime \prime}$ part concludes with a variation of the main melody in the left hand, along with right-hand trills. While the melody is stated, a countermelody also appears in the lower parts, and the sudden dramatic changes of dynamic markings emphasize the starting point of the melody. 
Example 4A-14 Dussek: "Allegro moderato ed espressivo" (mm. 311-312 \& 329 \& 341-343, in part $\left(\mathrm{a}^{\prime \prime \prime \prime}\right)$ of section $\left.\mathrm{A}^{\prime \prime \prime \prime}\right)$.
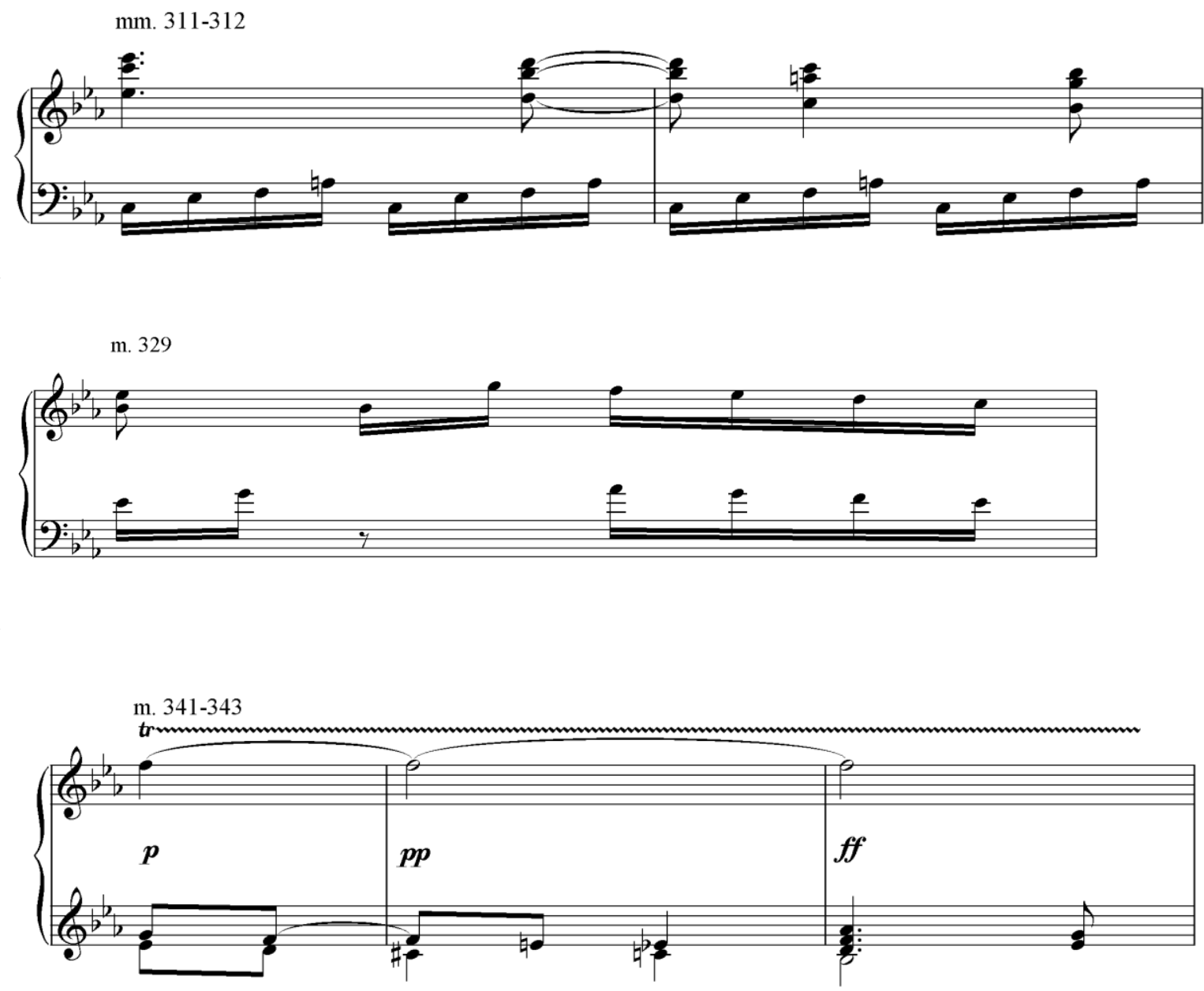

The coda begins with the first four measures of the (a) part, stated in E-flat Major, in $\mathrm{m}$.

347. The melody of the (a) part keeps reappearing with sixteenth-note accompaniment and alternates between the hands in sequential motion beginning in $\mathrm{m}$. 355. In this movement, as well as in the rest of the "Farewell" sonata, Dussek often uses sequences, and changes quickly between minor and major modes. Here, against a background of E-flat Major harmonies, the lowered sixth scale degree makes a sudden appearance, introducing a subdominant chord of E- 
flat minor in order to effect a mode change to the parallel minor in m. 369. In addition, Dussek employs a French augmented-sixth chord over descending octave chromatics in the left hand in mm. 371-373.

Example 4A-15 Dussek: "Allegro moderato ed espressivo" (m. 367-374, in coda).
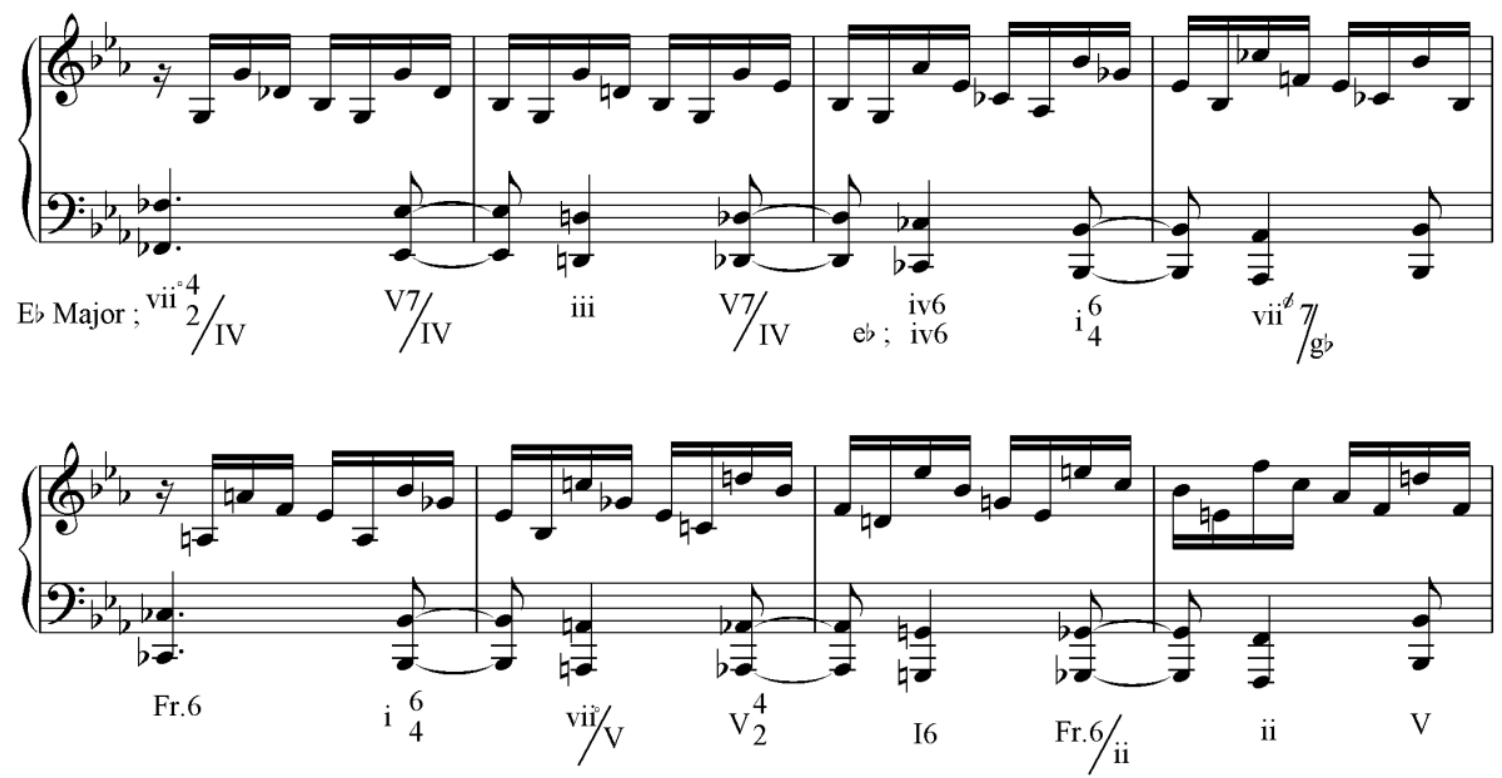

Even though Dussek indicates "Rondo" at the beginning of this movement and the principal theme recurs several times, this finale differs in two ways from the usual format of a rondo. The (a) material frequently returns in modified form throughout the movement, and this material is present in virtually all sections of the movement. Therefore, the fourth movement of Dussek's "Farewell" sonata bears many similarities to variation form. 


\section{B. Third Movement of Beethoven Sonata in E-flat, Op. 81a}

The third movement of Beethoven's piano sonata Op. 81a is in sonata form, with a fast introduction. This movement consists of five sections: 1) Introduction, 2) Exposition, 3) Development, 4) Recapitulation, and 5) Coda. Detailed sectional components of the movement, including measure number and key information, are presented in the table below. 
Table 4-2 Third movement of Beethoven Sonata in E-flat Major, Op. 81a (Sonata Form).

\begin{tabular}{|c|c|c|c|c|}
\hline \multicolumn{3}{|c|}{ Section } & Measure & Key \\
\hline \multicolumn{3}{|c|}{ Introduction } & $1-10$ & $\mathrm{~Eb}\left(\mathrm{~V}_{7}\right)$ \\
\hline \multirow{7}{*}{ Exposition } & \multicolumn{2}{|c|}{$1^{\text {st }}$ theme } & $11-28$ & $\mathrm{E} b$ \\
\hline & \multirow{3}{*}{$\begin{array}{c}\text { Transition } \\
\text { A }\end{array}$} & $\mathrm{a}$ & $29-36$ & $\mathrm{E} b$ \\
\hline & & $\mathrm{b}$ & $37-44$ & $\mathrm{G} b \rightarrow \mathrm{F}$ \\
\hline & & $\mathrm{c}$ & $45-52$ & $\mathrm{G} b \rightarrow \mathrm{F}$ \\
\hline & \multicolumn{2}{|c|}{$2^{\text {nd }}$ theme } & $53-68$ & $\mathrm{~B} b$ \\
\hline & \multicolumn{2}{|c|}{ Transition B } & $69-76$ & $\mathrm{~B} b$ \\
\hline & \multicolumn{2}{|c|}{ Closing figuration } & $77-81$ & $\mathrm{~B} b$ \\
\hline \multirow{3}{*}{\multicolumn{3}{|c|}{ Development }} & $81-93$ & eb \\
\hline & & & $94-103$ & $\mathrm{~B} \rightarrow \mathrm{G}$ \\
\hline & & & 104-109 & $\mathrm{G} \rightarrow \mathrm{C} \rightarrow \mathrm{A} b$ \\
\hline \multirow{7}{*}{ Recapitulation } & \multicolumn{2}{|c|}{$1^{\text {st }}$ theme } & $110-121$ & $\mathrm{E} b$ \\
\hline & \multirow{3}{*}{$\begin{array}{c}\text { Transition } \\
\mathrm{A}^{\prime}\end{array}$} & $\mathrm{a}$ & $122-129$ & $\mathrm{E} b$ \\
\hline & & b & 130-137 & $\mathrm{C} b(\mathrm{~B}) \rightarrow \mathrm{B} b$ \\
\hline & & $\mathrm{c}$ & $138-145$ & $\mathrm{Cb}(\mathrm{B}) \rightarrow \mathrm{B} b$ \\
\hline & \multicolumn{2}{|c|}{$2^{\text {nd }}$ theme } & $146-161$ & $\mathrm{E} b$ \\
\hline & \multicolumn{2}{|c|}{ Transition B' } & $162-171$ & $\mathrm{~Eb}$ \\
\hline & \multicolumn{2}{|c|}{ Closing figuration } & $171-176$ & $\mathrm{E} b$ \\
\hline \multirow{3}{*}{ Coda } & \multicolumn{2}{|c|}{$\mathrm{d}$} & $176-184$ & $\mathrm{~Eb}$ \\
\hline & \multicolumn{2}{|c|}{$\mathrm{e}$} & $185-190$ & $\mathrm{E} b$ \\
\hline & \multicolumn{2}{|c|}{$\mathrm{f}$} & 191-196 & $\mathrm{E} b$ \\
\hline
\end{tabular}

The third movement of the sonata begins with a "Vivacissimamente" introduction in Eflat Major. At the beginning of this movement, Beethoven marks the tempo in German "Im lebhaftesten Zeitmaße [In the liveliest tempo]." The introduction forms a connection between the second and third movements. The introduction is in $6 / 8$ meter, and for the duration of its ten 
measures prolongs a dominant seventh chord of E-flat Major. In mm. 1-8, the dominant seventh chord is presented in an arpeggiated figure, using different registers. Beethoven alternates descending minor and major seconds to reach the B-flat tone at the beginning of the exposition in mm. 9-10.

Example 4B-1 Beethoven: "Vivacissimamente" (third movement) from Sonata in E-flat Major, Op. 81a (mm. 1-2 and 9-10).
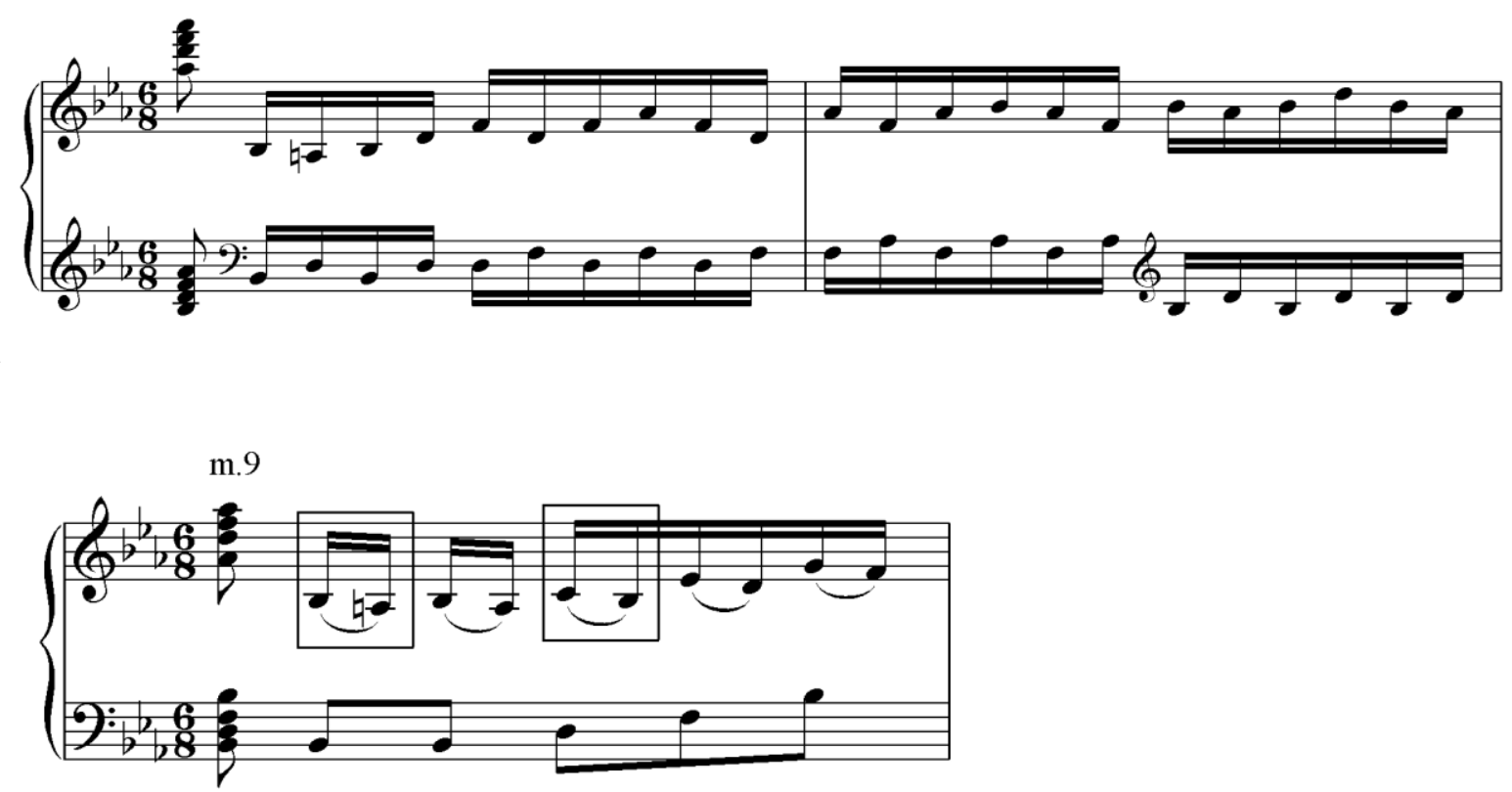

The exposition consists of two main themes and a closing theme. In mm. 11-16, the first theme is presented with tonic of the E-flat Major. The first theme exhibits a melody-andaccompaniment texture; the melody seems to be an arpeggiated version of the chords in the left hand. 
Example 4B-2 Beethoven: "Vivacissimamente" (mm. 11-12).

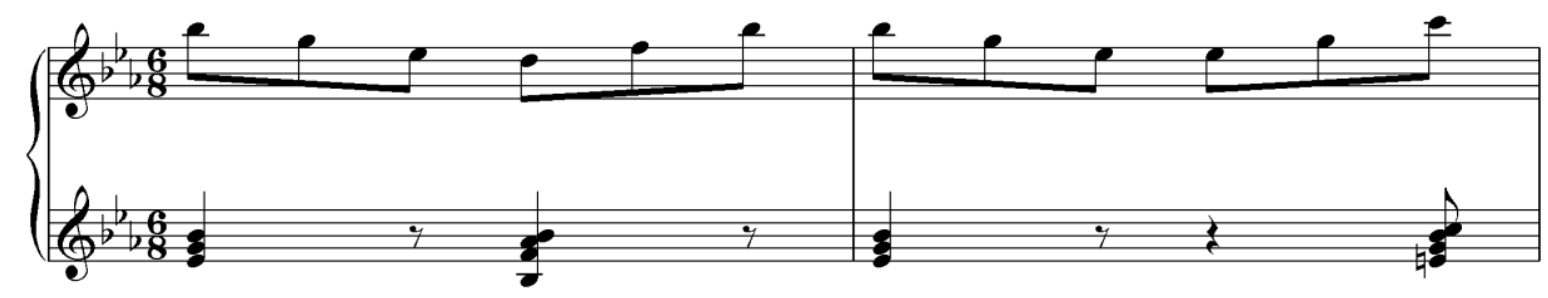

This theme occurs three times; each statement is the same length, but gets a varied presentation. For example, the second time the theme appears, in mm. 17-22, the left hand plays the principal melody, while the right hand presents a counter-melody.

Example 4B-3 Beethoven: "Vivacissimamente" (mm. 17-18).

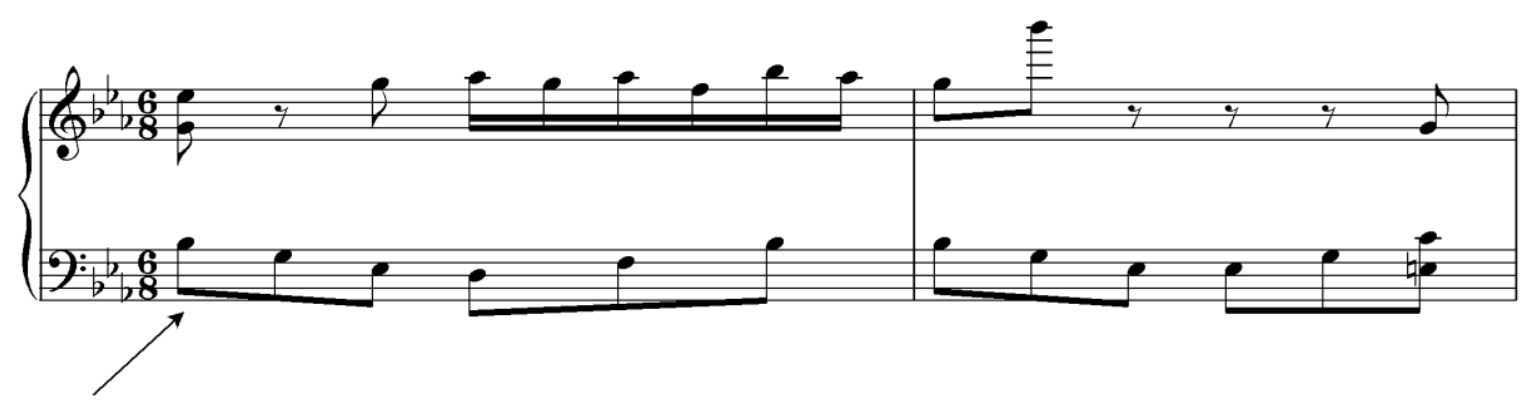

In mm. 23-28, again the left hand presents the melody of the first theme, this time one octave lower. The melody is accompanied by sixteenth-note octave arpeggios in the right hand. 
Example 4B-4 Beethoven: "Vivacissimamente" (mm. 23-24).

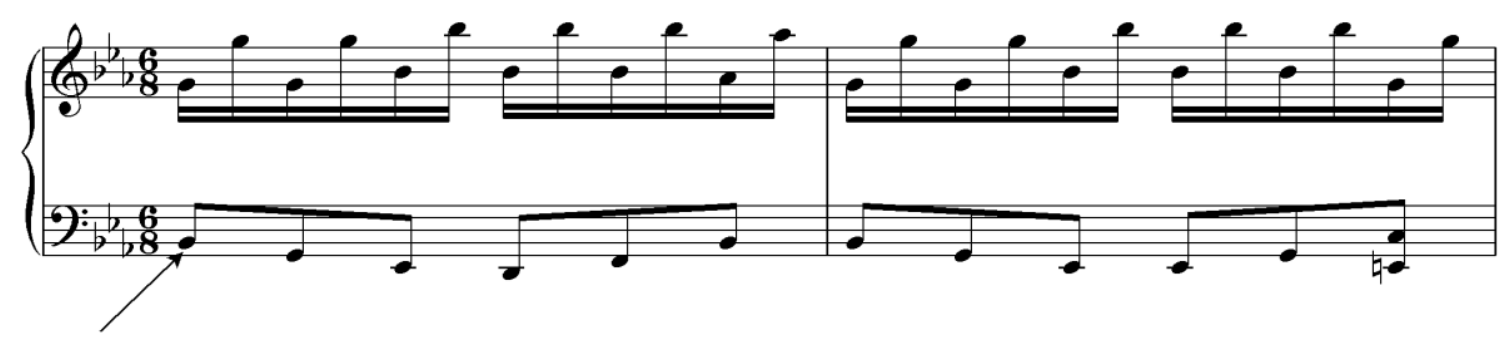

The "Transition A" section starts in m. 29 and contains three parts. The first part consists of eight measures that emphasize the tonic and dominant chords of E-flat Major over an E-flat pedal tone.

Example 4B-5 Beethoven: "Vivacissimamente" (mm. 29-30).

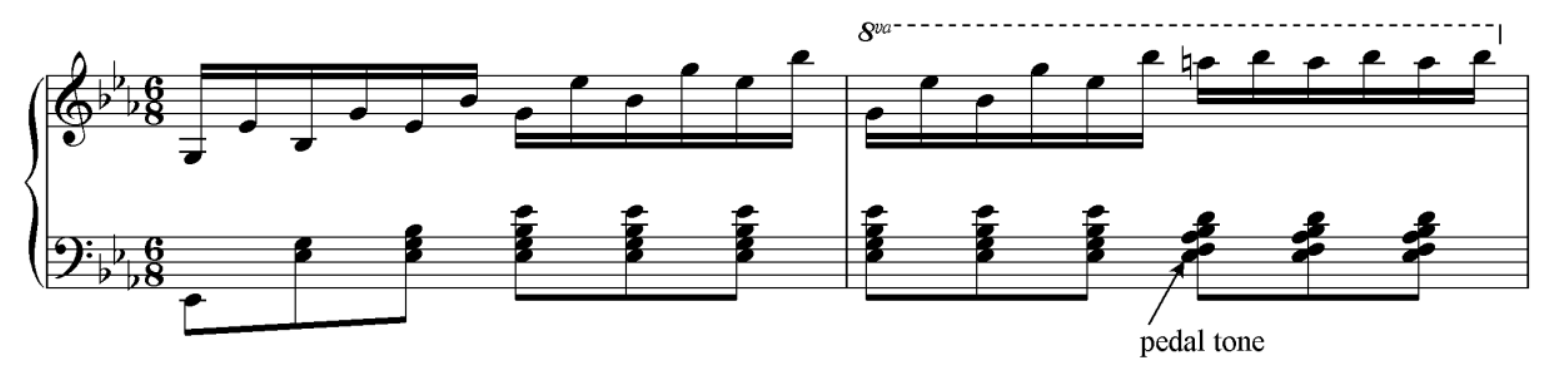

The second part of the transition is also made up of eight measures, subdivided into fourmeasure units. The first four measures reveal arpeggiated figures in G-flat Major, which then move down a half step to F Major. The texture of this second part is monophonic. Tovey mentions that the tonality of this second part focuses on "the flat sixth and dominant of B-flat."122

122 Tovey, The Classics of Music, 38. 
Example 4B-6 Beethoven: "Vivacissimamente" (mm. 37-44).

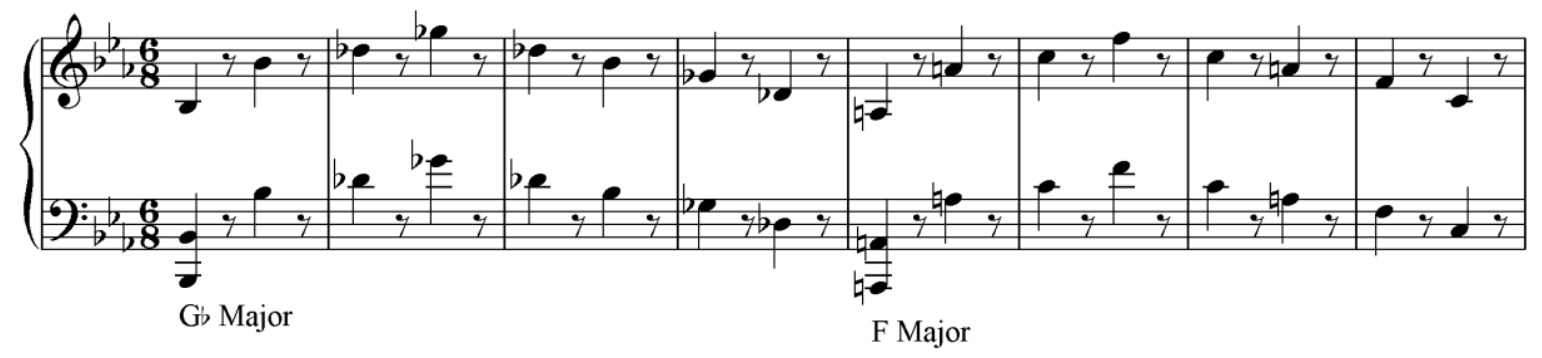

The third part of the transition contains the same key progression as the second part above, and also consists of eight measures. However, the melody, decorated by grace-note ornaments, is based on the tune of the second part.

Example 4B-7 Beethoven: "Vivacissimamente" (mm. 45-47).

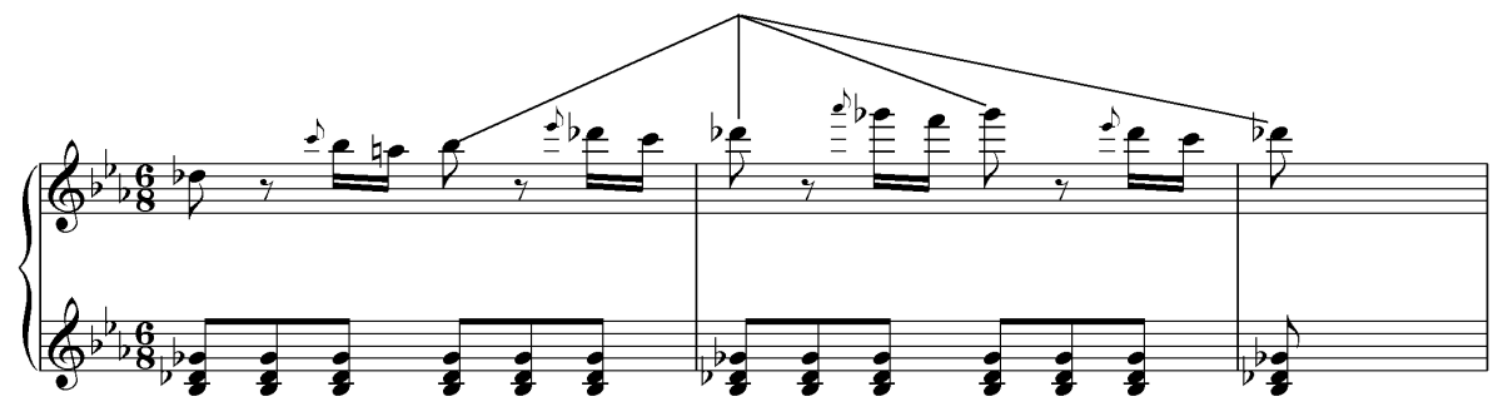

The second theme begins in $\mathrm{m} .53$ in the new tonic of B-flat Major, the dominant key of E-flat Major. The phrase structure of the second theme is symmetrical, using a common combination of $2+2+4$. In mm. 53-54, the first two measures of the theme are presented in polyphony, including three different elements: (a), (b), and (c). The (a) element, consisting of dotted quarter notes, is presented in the soprano. The (b) element is composed of sixteenth notes 
with a major-second interval in a trill figure; this element is placed in the alto. The (c) element appears in the tenor, and the rhythm of this element consists of quarter-notes and eighth notes $(\downarrow$ $\delta\lrcorner \delta)$. In mm. 55-56, these two measures are repeated, followed by rapid running sixteenth notes in the right hand, accompanied by block chords in left hand.

Example 4B-8 Beethoven: "Vivacissimamente" (mm. 53-54).

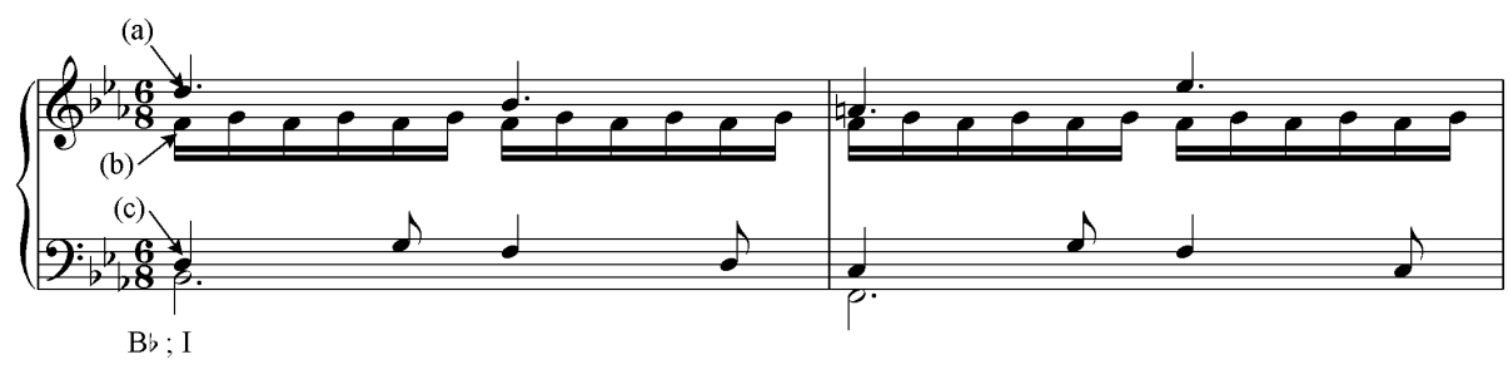

“Transition B” begins in m. 69 and features a descending four-note chromatic step-wise melody in octaves, with sixteenth-note accompaniment.

Example 4B-9 Beethoven: "Vivacissimamente" (mm. 69-70).

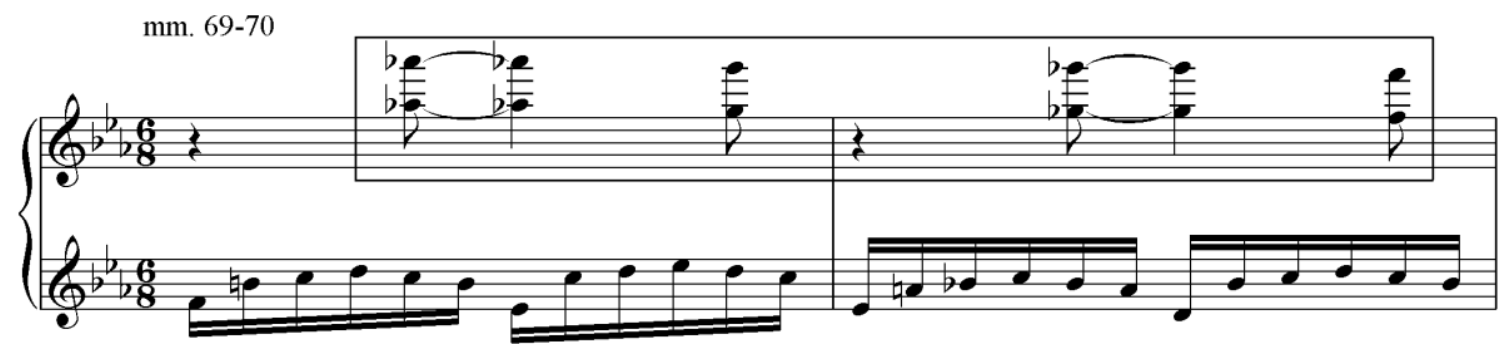


After Transition B, the closing figuration follows in $\mathrm{mm}$. 77-81. While tonic and dominant chords of B-flat Major are played in the left hand, one-measure rising scales repeat three times in the right hand, concluding with a tonic chord of B-flat Major played three times in different octaves.

Example 4B-10 Beethoven: "Vivacissimamente" (mm. 77 \& 80-81).
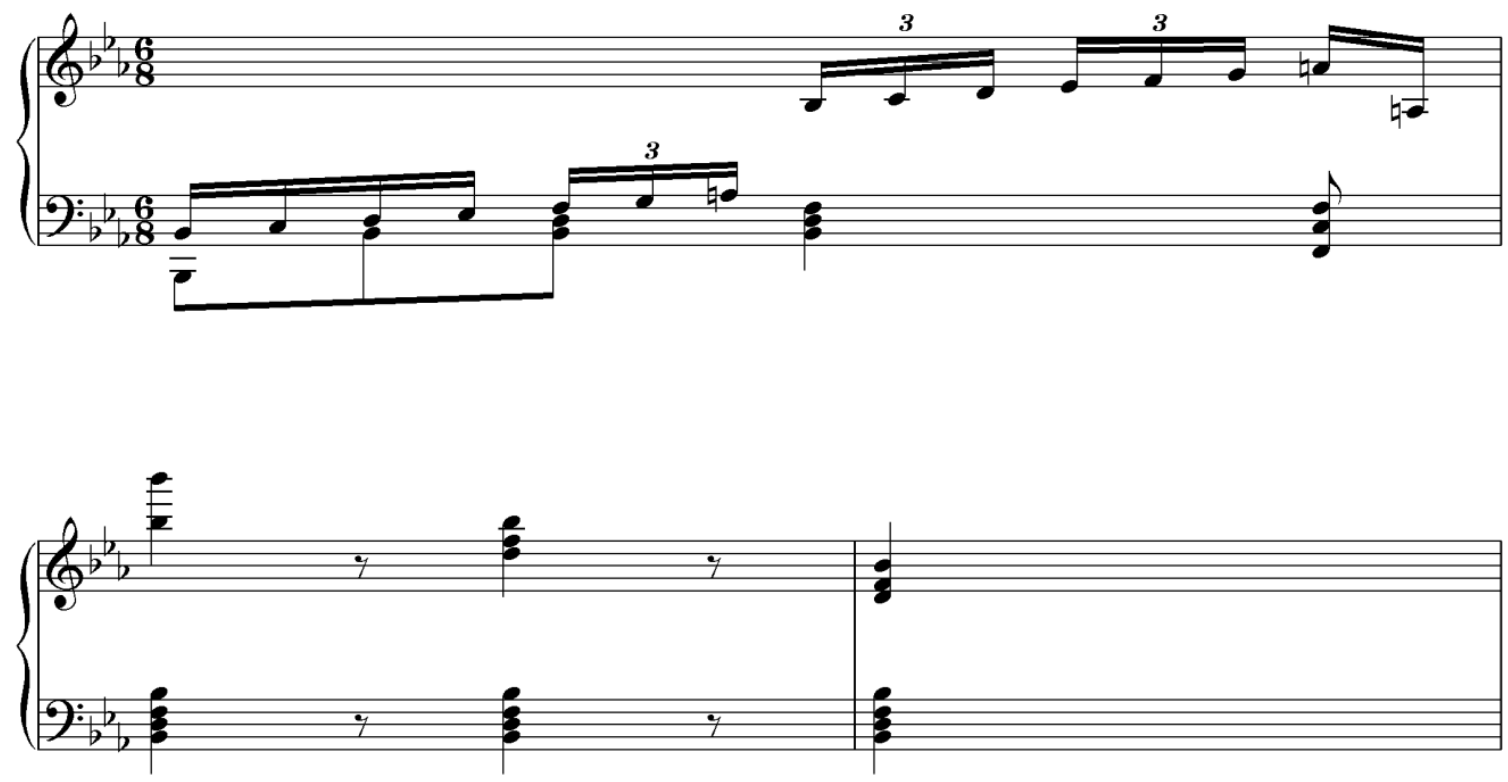

After the exposition is repeated, the development section covers mm. 81-107, which can be divided into three parts. In the first part, two elements from the first theme and Transition B are presented. In mm. 81-83, the opening element of the first theme appears in E-flat minor, followed by an ascending four-note chromatic step-wise figure in octaves. These chromatic octaves are based on the descending four-note chromatic step-wise figure from Transition B (see examples 4B-2 and 4B-9). 
Example 4B-11 Beethoven: "Vivacissimamente" (mm. 81-85).

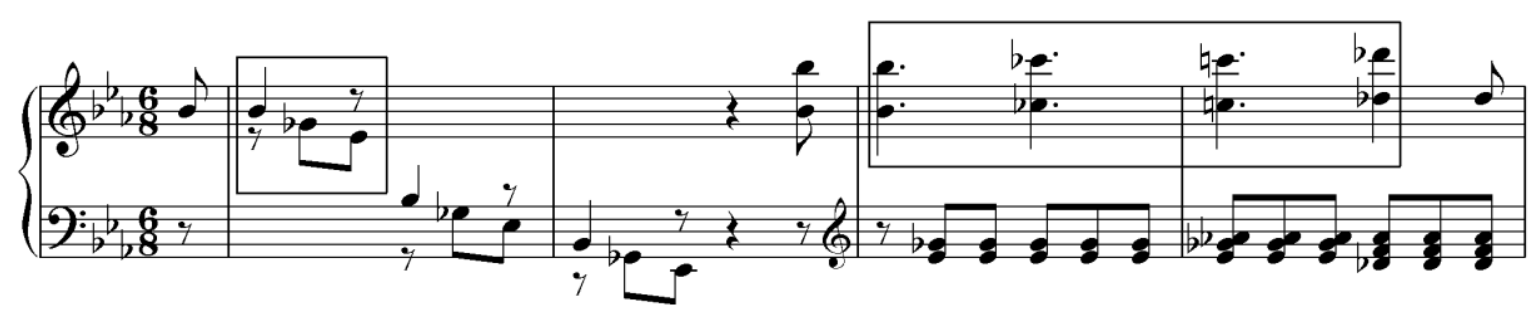

The second part of the development section begins with three elements, (a), (b), and (c) from the second theme. In mm. 94-95, the position of these elements differs from the second theme. Here, the three elements are placed in reverse order - (c)-(b)-(a) - and descend from the alto to the bass. The three elements then reappear in their original positions in mm. 96-97.

Example 4B-12 Beethoven: "Vivacissimamente" (m. 94 and 96).

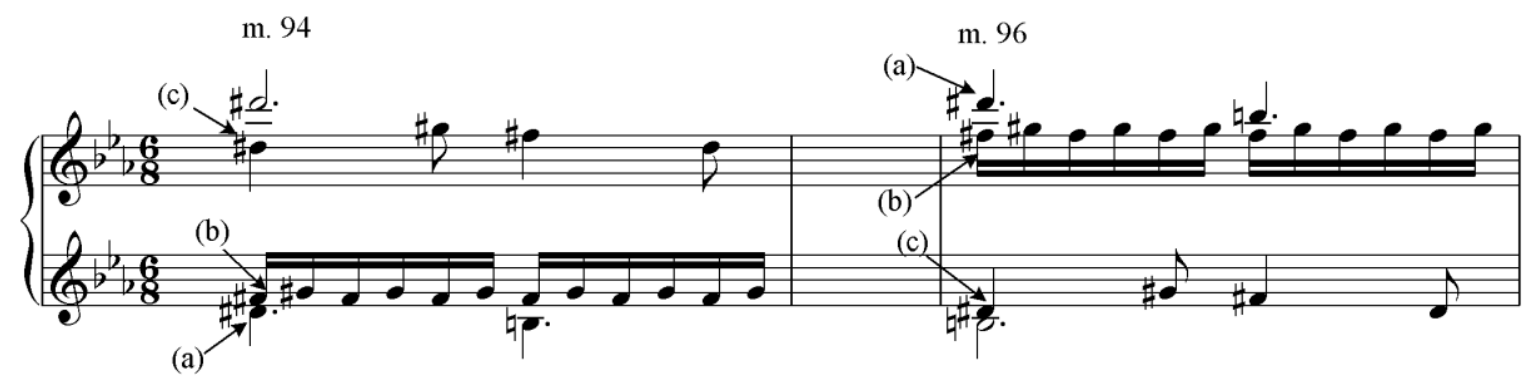

The third part of the development begins in $\mathrm{m} .104$ with an element of the first theme. After three-part imitation is presented in G Major and C Major in mm. 104-107, the first-theme element is played in the soprano with sixteenth-note accompaniment in A-flat Major, providing a seamless connection to the recapitulation. 
Example 4B-13 Beethoven: "Vivacissimamente" (mm.104-105 and 108-109).
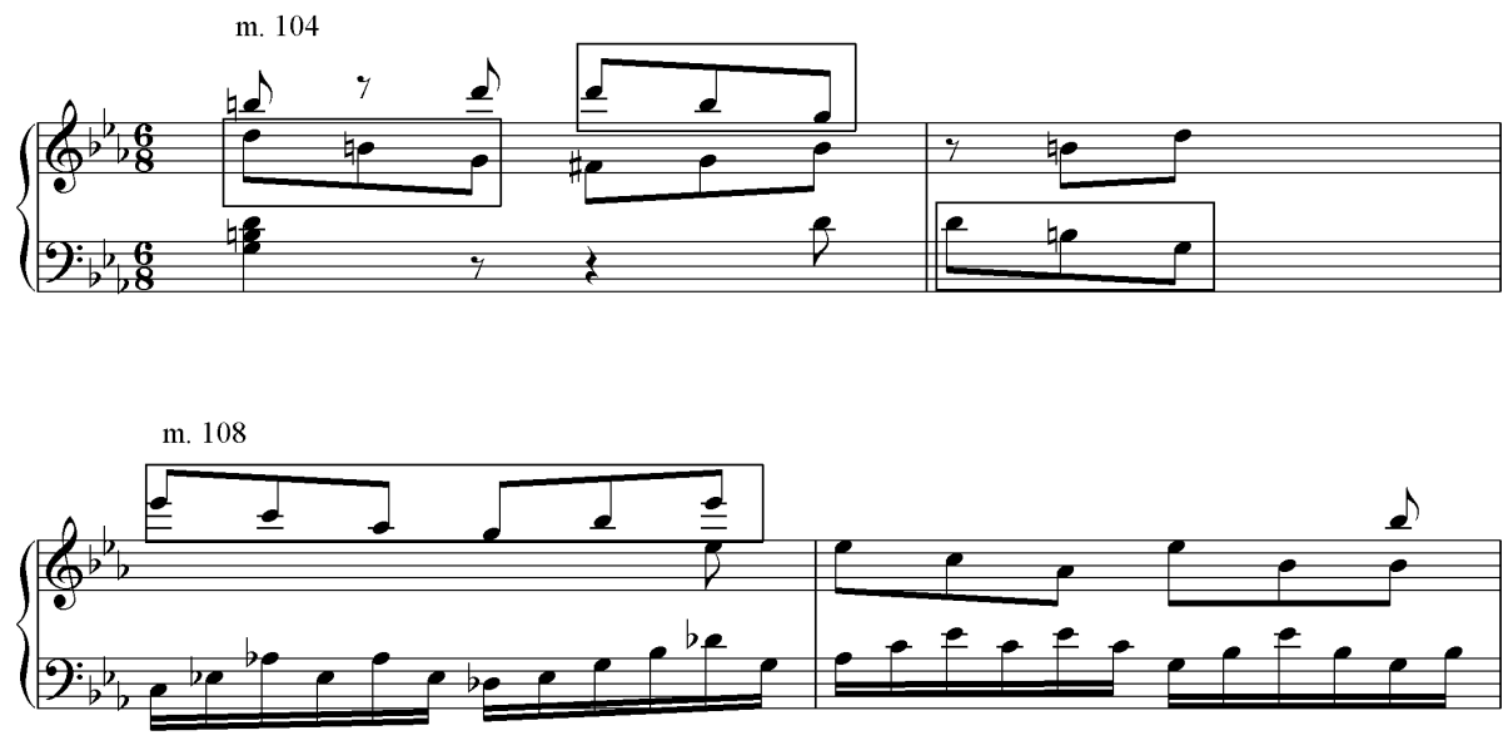

The recapitulation section starts in $\mathrm{m} .110$, and all themes from the exposition return in the home key of E-flat Major. The themes are presented in a manner identical to their occurrences in the exposition, with some slight exceptions. One is that the texture and length of the first theme are changed in the recapitulation, and this material only appears in its homophonic version, without the polyphonic reworking heard in the exposition. In addition, the presentation of the melody is different, as it is doubled at the octave and accompanied by a sixteenth-note pattern. 
Example 4B-14 Beethoven: "Vivacissimamente" (m. 110).

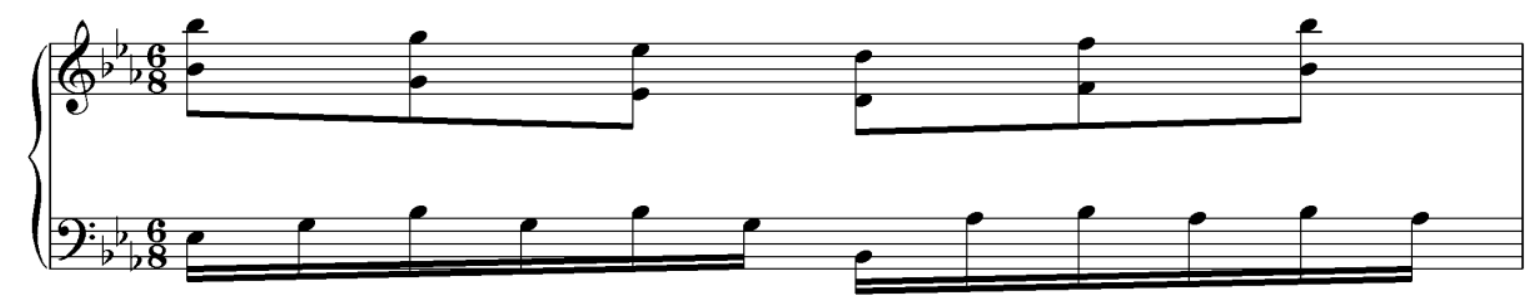

Another change concerns the length and modulation pattern of the transition. In the second and the third parts of Transition A in the recapitulation, C-flat Major and B-flat Major are employed to reconfirm E-flat Major for the second theme, instead of G-flat Major and F Major (see example 4B-6). Transition B is also extended by two measures.

Example 4B-15 Beethoven: "Vivacissimamente" (mm. 130-131 and 134-135).

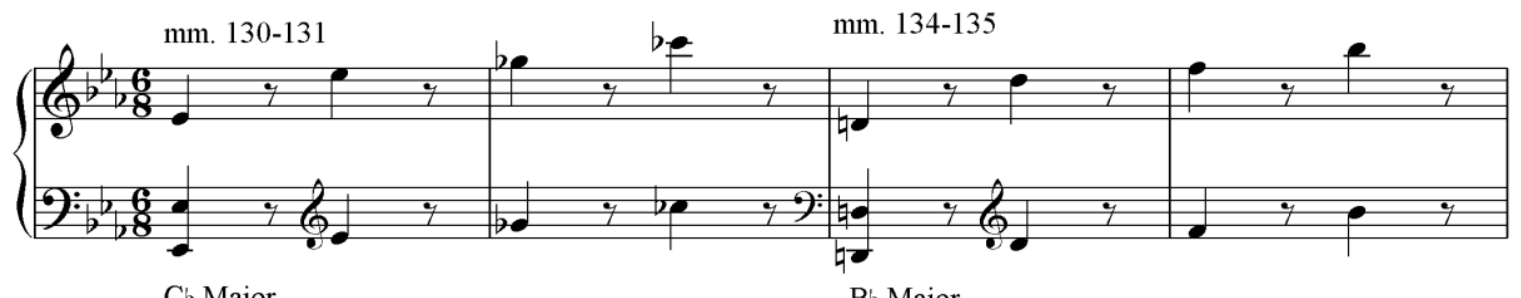

The coda begins with a new tempo marking, "Poco Andante," in m. 176. As Tovey approvingly comments:

"Its sudden change to a slow tempo is the most effective and unexpected bold stroke that could possibly be devised." "123

123 Tovey, The Classics of Music, 43. 
The coda can be divided into three parts. The first part presents the first theme, and develops it through rising sequences in E-flat Major.

Example 4B-16 Beethoven: "Vivacissimamente" (mm. 176-180, soprano).

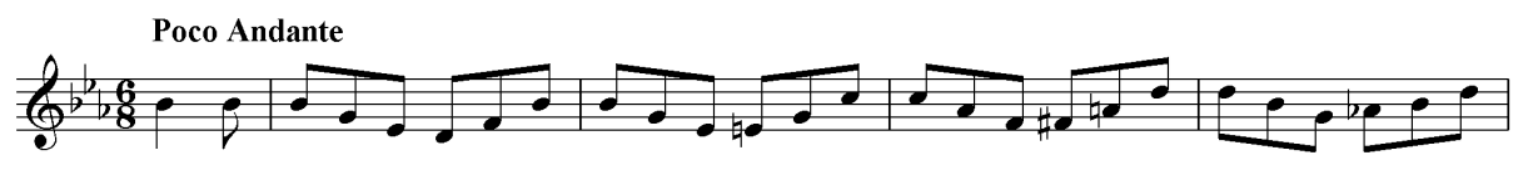

The second part of the coda is a variation based on the first theme element, moving toward the final part of the coda through sequential motion.

Example 4B-17 Beethoven: "Vivacissimamente" (mm. 185-186, soprano).

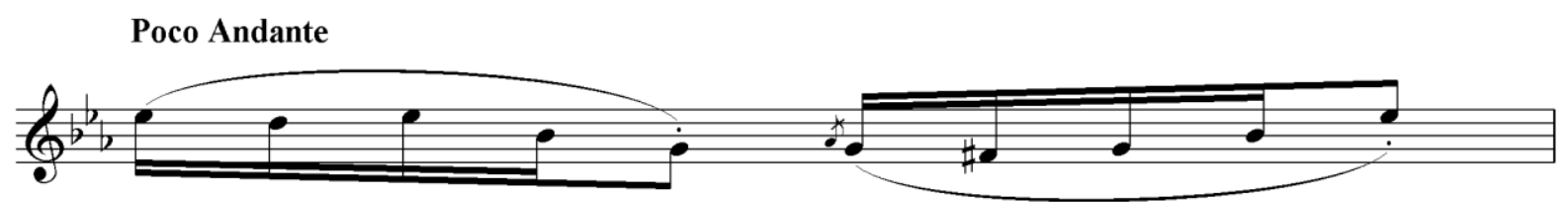

The final part of the coda begins suddenly at the original tempo of the movement, and ends with a perfect authentic cadence. 


\section{Chapter 6}

\section{Summary and Comparison}

The similarities between Dussek's and Beethoven's works have been studied by several scholars, including Blom and Ringer. In the course of such presentations, the two piano sonatas entitled "Farewell" by Dussek and Beethoven are often introduced as a profitable point of comparison.

The previous chapters present a brief analysis of each movement of the two "Farewell" sonatas, focusing on form, tonality, and texture. On the basis of the analysis, this chapter will briefly compare the similarities and dissimilarities between the two "Farewell" sonatas, which are separated by ten years in their respective dates of composition, with the Dussek sonata being the earlier of the two works.

\section{Similarities}

There are several points of similarity between the two sonatas. The most obvious similarities are that both of the sonatas are written in the same key, E-flat Major, and that they are given the same programmatic title.

In both first movements, the respective composers include a slow introduction and use material from the beginning of this section to create the main themes of the exposition. Dussek employs the neighbor-tone figure of the introduction (see example 1A-1) as the basis for the first main theme (see example 1A-2). In addition, the closing theme is also based on this material (see 
example 1A-6). Dussek uses the neighbor-tone figure as a primary source of material throughout the first movement.

This compositional technique, involving the extensive development of small motivic ideas, also appears in the first movement of Beethoven's sonata Op. 81a. Beethoven unites the first movement through the use of the descending three-note step-wise figure from the beginning of the introduction (see example 1B-1). All of the significant formal entities of the sonata-form structure of the movement, such as the first, second, and closing themes, the transition, and the coda, are based on this figure, in augmentation, diminution, or inversion (see examples 1B-3, 1B-4, 1B-6, 1B-7, 1B-8, 1B-11, and 1B-12).

Similar textures are used in the two second movements. The beginning of each movement features dotted-rhythm patterns in 2/4 meter (see examples $2 \mathrm{~A}-1$ and $2 \mathrm{~B}-1$ ), and these figures become gradually thicker in texture. Moreover, both movements feature a song-like melody accompanied by thirty-second notes. Dussek uses this melody and accompaniment combination in the development section (see example 2A-8), while Beethoven presents it in the second thematic section (see example 2B-3).

There are also several similarities between the first movement of Dussek's "Farewell" sonata and the third movement of Beethoven's "Farewell" sonata. These two movements are in the same meter, 6/8, and contain similar melody and accompaniment patterns. When they present their first themes, the melody appears first in the right hand and then migrates to the left hand. Also, the theme is accompanied by sixteenth-note figures in inner or outer voices to emphasize the expanding quality of the themes when they occur for a third time (see examples $1 \mathrm{~A}-2$ and 1A-3, 4B-2, and 4B-4). 
In the first movement of the Beethoven sonata and the fourth movement of the Dussek, the same tune occurs. Dussek's fourth movement begins with a melody that includes a descending step-wise figure, starting with G-F-Eb (see example 4A-1). These three descending notes are also introduced as a "Lebewohl" motive in the soprano at the beginning of the first movement of Beethoven's sonata (see example 4B-1). Moreover, the same "Lebewohl" motive, both soprano and alto voices, appears in the fourth movement of Dussek in retrograde (see example 4A-3).

\section{Dissimilarities}

Even though these two "Farewell" sonatas have some features in common, they also contain some differences in their structures and compositional techniques.

There are three basic and obvious differences between the two pieces: 1) the number of movements, 2) the form of each movement, and 3) the key relationship between movements.

Dussek's "Farewell" sonata consists of four movements:

First movement: Sonata form in E-flat Major, Second movement: Sonata form in B Major (C-flat Major), Third movement: Minuet and trio in G-sharp minor, and Fourth movement: Rondo in E-flat Major.

As discussed above, Dussek uses an unusual key system for this sonata. The second movement is in B Major, the enharmonic equivalent of C-flat Major, the lowered sixth scale degree of E-flat. The third movement begins in G-sharp minor, the relative minor key of B Major, and concludes in A-flat Major, which is the subdominant key of E-flat Major. The final movement returns to Eflat Major. The lowered sixth scale degree is one of the most significant recurring ideas in Dussek's "Farewell" sonata. Dussek employs this not only for the key scheme of the sonata but 
also for the sudden change of mood within movements. In the second movement, Dussek lowers the sixth scale degree to create an atmosphere of tension against the B-Major harmonies of the movement (see example 2A-3).

In contrast, Beethoven's "Farewell" sonata consists of three movements:

First movement: Sonata form in E-flat Major, Second movement: Binary form in $\mathrm{C}$ minor, and Third movement: Sonata form in E-flat Major.

Beethoven remains in closely-related keys throughout the piece, in contrast to Dussek's journey to remote keys in the middle movements. As mentioned above, the second movement of Beethoven's sonata begins in $\mathrm{C}$ minor, the relative minor of E-flat Major. Beethoven uses a third relationship between the first movement and second movement. Employing a third relationship between movements is a well-known feature in many of Beethoven's works. Moreover, there is no clear break between the second and third movements; the second movement connects directly to the third without any rest or double bar. The introduction of the third movement seems to have a role as a bridge between the two movements (see example 4B-1).

In general, the harmonic language of Dussek's sonata includes more unusual features than does Beethoven's. Dussek often uses non-harmonic tones such as neighbor tones and suspensions (see examples 1A-1 and 4A-1); he also enjoys an occasional sudden change between major and minor mode (see examples 1A-5 and 4A-4). Moreover, he frequently uses expressive chromatics (2A-5), successive diminished chords (2A-10 and 4A-6), and augmented chords (2A3 and 4A-15). In a particularly striking passage, a chain of diminished chords helps bring about a modulation to a remote key (see example 4A-6).

When Newman introduces Dussek in the final volume of his series of books that survey the sonata in several eras, he mentions that: 
"In spite of his early life dates, the notable Czech pianist and composer Jan Ladislav Dussek was deferred to the present volume because of significant preRomanticisms in his musical style and piano writing."

Even though both of the "Farewell" sonatas are written in the traditional sonata structure of the time, Dussek's piece makes use of more unusual elements including remote key relationships, thick chords, and chromatics with complicated accidental notes. Therefore, Dussek's "Farewell" sonata gives the appearance of having been composed later than Beethoven's "Farewell" sonata, even though it was actually written ten years earlier.

${ }^{124}$ Newman, The Sonata since Beethoven; the Third and Final Volume of a History of the Sonata Idea, 658-659. 


\section{Selected Bibliography}

\section{Books}

Blom, Eric. Classics: Major and Minor with Some Other Musical Ruminations. New York: Da Capo, 1973.

Drake, Kenneth. The Beethoven Sonatas and the Creative Experience. Bloomington: Indiana University Press, 2000.

Gillespie, John. Five Centuries of Keyboard Music: An Historical Survey of Music for Harpsichord and Piano. Belmont, CA: Wadsworth, 1965.

Gordon, Stewart. A History of Keyboard Literature: Music for the Piano and its Forerunners. New York: Schirmer Books, 1996.

Grout, Donald Jay, J. Peter Burkholder, and Claude V. Palisca. A History of Western Music. 7th ed. New York: W.W. Norton, 2006.

Harding, H. A. Analysis of Form as Displayed in Beethoven's Thirty-Two Pianoforte Sonatas: With a Description of the Form of Each Movement for the Use of Students. London: Novello, 1901.

Kirby, Frank E. A Short History of Keyboard Music. New York: Free Press, 1966.

Kresky, Jeffrey. Tonal Music: Twelve Analytic Studies. Bloomington: Indiana University Press, 1977.

Nettl, Paul. Forgotten Musicians. New York: Philosophical Library, 1951.

Newman, William S. The Sonata Since Beethoven: The Third and Final Volume of a History of the Sonata Idea. Chapel Hill: University of North Carolina Press, 1969.

- The Sonata in the Classic Era: The Second Volume of a History of the Sonata Idea. Chapel Hill: University of North Carolina Press, 1963.

Randel, Don Michael. The Harvard Dictionary of Music. 4th ed. Cambridge: Belknap Press of Harvard University Press, 2003.

Rosen, Charles. The Classical Style: Haydn, Mozart, Beethoven. New York: W.W. Norton, 1971.

- Sonata Forms. New York: W.W. Norton, 1988. 
Schiffer, Leo. Johann Ladislaus Dussek: Seine Sonaten und Seine Konzerte [Johann Ladislaus Dussek: His sonatas and concertos]. New York: Da Capo, 1973.

Spohr, Louis. Louis Spohr's Autobiography. London: Reeves \& Turner, 1878.

Temperley, Nicholas, ed. The London Pianoforte School 1766-1860: Clementi, Dussek, Cogan, Cramer, Field, Pinto, Sterndale Bennett, and Other Masters of the Pianoforte. New York: General Music Publishing Co., 1984.

Thayer, Alexander Wheelock, Elliot Forbes, Hermann Deiters, Hugo Riemann, and Henry Edward Krehbiel. Thayer's Life of Beethoven. Princeton: Princeton University Press, 1970.

Tovey, Donald Francis. A Companion to Beethoven's Pianoforte Sonatas: Complete Analyses. New York: AMS Press, 1976.

. The Classics of Music: Talks, Essays, and Other Writings Previously Uncollected. Oxford: Oxford University Press, 2001.

\section{Dissertations}

Archibald, Rebecca H. "Understanding Beethoven's Piano Sonata in E-Flat Major, Opus 81a, as Program Music." MM diss., California State University, 1990.

Carroll, M. "J.L. Dussek and His Role in the Development of the Piano Repertory." MPhil diss., Open University, United Kingdom, 2002.

Craw, Howard Allen. "A Biography and Thematic Catalog of the Works of J. L. Dussek (17601812)." PhD diss., University of Southern California, 1964.

DePalma, Sarah. "Beethoven's Contribution to the Piano Sonata." MM diss., Oakland University, 1981.

Douglas, John Thomas. "The Pianos of Beethoven's Day as They Effect an Interpretation of Opus 81a: The "Les Adieux" Piano Sonata." MM diss., Bowling Green State University, 1979.

Doutt, Margaret Elizabeth. "The Concertos of Jan Ladislav Dussek (1760-1812)." PhD diss., Musicology from University of Kentucky, 1989.

Durham, Rebecca Christensen. "The Lebewohl Motif : Meaning, Form, and Quotation." MA diss., University of Utah, 2005.

Fortner, Lewis Millard. "The Piano Sonatas of J.S. Dussek (1760-1812)." MM diss., West Virginia University, 1970. 
Garrard, Luann. "Motivic Relationships in the First Movements of Two Beethoven Piano Sonatas--Opus 13 and Opus 81a." MA diss., University of Rochester, 1981.

Grossman, Orin Louis. "The Solo Piano Sonatas of Jan Ladislav Dussek." PhD diss., Musicology from Yale University, 1975.

Kim, Hwa Young. "Jan Ladislav Dussek (1760-1812): His Little-Known Works for Piano Solo." DMA diss., University of Maryland, 1997.

Kopple, Suzanne J. "An Analysis of Beethoven's Piano Sonata in Eb Major, Opus 81a." MA diss., Stanford University, 1984.

Lau, Sandy Po Man. "A Survey of the Development of the Pianoforte and Stylistic Change in Beethoven's 32 Piano Sonatas." MM diss., University of Sheffield, 1990.

Rhoden, Lori Ellen. "A Pedagogical Analysis of Selected Intermediate-Level Sonatinas by Clementi, Dussek, Diabelli, and Kuhlau." DMA diss., University of South Carolina, 1998.

Rudolf, Kenneth Emanuel. "The Piano Sonatas of J. L. Dussek and Ludwig Van Beethoven; A Comparative Study." MA diss., University of Washington, 1975.

Sanchez, Luis. "An Analysis of the Sonata No. 26 Op. 81a "Les Adieux" by Ludwig Van Beethoven." MM diss., Ball State University, 1997.

Schmitt Scheubel, Robert. "Johann Ludwig Dussek im Spiegel der Deutschen, Französischen und Englischen Tagespresse Seiner Zeit, Nebst Verzeichnis Seiner in Berliner Bibliotheken Befindlichen Werke, der Auffindbaren Autographen, Handschriften und Schallaufnahmen [Jan Ladislav Dusík reflected in the German, French, and English daily press of his times, together with an index of his works held in Berlin libraries, the available autographs, the manuscripts, and the recordings]." PhD diss., Musikwissenschaft from Technische Universität Berlin, 1994.

\section{Articles}

Dodson, Alan. "Performance, Grouping and Schenkerian Alternative Readings in some Passages from Beethoven's Lebewohl Sonata." Music Analysis 27, no. 1 (March 2008): 107-34. http://search.ebscohost.com.www.libproxy.wvu.edu/login.aspx?direct=true\&db=rih\&AN=2 008-07338\&site=ehost-live [accessed February 12, 2011].

Gelat, Frank. "Beethoven's Music: The Link between the Individual and Universal." The Beethoven Journal 11, no. 2 (September 1996): 11-7. 
Howard Allen Craw. "Dussek." In Grove Music Online. Oxford Music Online, http://www.oxfordmusiconline.com/subscriber/article/grove/music/44229 (accessed January 23, 2011).

Joseph Kerman, et al. "Beethoven, Ludwig van." In Grove Music Online. Oxford Music Online, http://www.oxfordmusiconline.com/subscriber/article/grove/music/40026 (accessed January 31, 2011).

Lee, Win Alison. "Elements of Romanticism in Piano Sonata Op. 43 by Jan Ladislav Dussek." South Central Music Bulletin 2, no. 2 (Spring 2004): 23-31.

Margaret Cranmer and Peter Ward Jones. "Clementi." In Grove Music Online. Oxford Music Online, http://www.oxfordmusiconline.com/subscriber/article/grove/music/05937 (accessed February 11, 2011).

Marvin, Frederick. "Jan Ladislav Dussek." HiFi-Stereophonie 18, no. 7 (January 1979): 874-79.

Moe, Orin. "The Implied Model in Classical Music." Current Musicology, no. 23 (January 1977): 46-55.

O, Yun-rog. "Dyuseg Yi Londeon Sidae Yi Jaggog Yangsig [Compositional style of Dussek in his London period]." Eum'Ag Gwa Minjog 28 (January 2004): 253-81.

Ringer, Alexander L. "Beethoven and the London Pianoforte School." The Musical Quarterly 56, no. 4 (October 1970): 742-58.

Schwarting, Heino. "The Piano Sonatas of Johann Ladislaus Dussek (Jan Ladislav Dusík)." Piano Quarterly 91 (September 1975): 41-5.

Song, Mu-gyeong. "Betoben Pi'Ano Sonata e Natananeun Koda (Coda) Ceori Gibeob [Beethoven's handlings of coda in his piano sonatas]." Seoyang Eum'aghag/Journal of the Musicological Society of Korea 16 (January 2008): 11-45.

__. "Betoben Piano Sonata Eseo Sayongdoen Neurin Seojubu Yi Cabyeolhwadoen Yeoghal [The distinctive role of the slow introduction in Beethoven's piano sonatas]." Nangman Eum'ag/Nangman Quarterly 58 (March 2003): 5-20.

Susan Kagan. "Rudolph, Archduke of Austria." In Grove Music Online. Oxford Music Online, http://www.oxfordmusiconline.com/subscriber/article/grove/music/24087 (accessed March 10, 2011).

Truscott, Harold. "Dussek and the Concerto." The Music Review 16, no. 1 (February 1955): 2953. 


\section{Scores}

Beethoven, Ludwig van. Klaviersonate Nr. 26 Es-dur Opus 81a (Les Adieux). Edited by Bertha Antonia Wallner. München: G. Henle Verlag, 1980.

Dussek, Jan Ladislav. Selected Piano Works. Edited by H. Allen Craw. Vol. 1 of Recent Researches in the Music of the Nineteenth and Early Twentieth Centuries. Madison, WI: AR Editions, 1979.

Dusík, Jan Ladislav. Sonate I-VII for Piano. Vol. 46 of Musica Antiqua Bohemica. Praha: Editio Supraphon, 1969. 